NBER WORKING PAPER SERIES

\title{
THE IMPACT OF FREE SECONDARY EDUCATION: EXPERIMENTAL EVIDENCE FROM GHANA
}

\author{
Esther Duflo \\ Pascaline Dupas \\ Michael Kremer \\ Working Paper 28937 \\ http://www.nber.org/papers/w28937 \\ NATIONAL BUREAU OF ECONOMIC RESEARCH \\ 1050 Massachusetts Avenue \\ Cambridge, MA 02138 \\ June 2021
}

This study is registered in The American Economic Association's registry for randomized controlled trials under RCT ID AEARCTR-0000015. The study protocol was approved by the IRBs of UCLA, Stanford, MIT and IPA. We thank the Ghana Education Service and IPA Ghana for their collaboration, and Jonathan Addie for outstanding project management. We are grateful to Ishita Ahmed, Madeline Duhon, Gabriella Fleischman, Erin Grela, Jinu Koola, Stephanie Kabukwor Adjovu, Ryan Knight, Victor Pouliquen, Nicolas Studer, Mark Walsh, and Alexandre Simoes Gomes for outstanding research assistance. The funding for this study was provided by the NIH (Grant \#R01 HD039922), the JPAL Post-Primary Education Initiative, the IGC, 3ie, the Partnership for Child Development and the Nike Foundation. We thank them, without implicating them, for making this study possible. Dupas gratefully acknowledges the support of the NSF (award number 1254167). We also thank Rachel Glennerster for valuable input on the paper. The views expressed herein are those of the authors and do not necessarily reflect the views of the National Bureau of Economic Research.

NBER working papers are circulated for discussion and comment purposes. They have not been peer-reviewed or been subject to the review by the NBER Board of Directors that accompanies official NBER publications.

(C) 2021 by Esther Duflo, Pascaline Dupas, and Michael Kremer. All rights reserved. Short sections of text, not to exceed two paragraphs, may be quoted without explicit permission provided that full credit, including $(\odot$ notice, is given to the source. 
The Impact of Free Secondary Education: Experimental Evidence from Ghana

Esther Duflo, Pascaline Dupas, and Michael Kremer

NBER Working Paper No. 28937

June 2021

JEL No. H52,I26,O12

\title{
ABSTRACT
}

Following the widespread adoption of free primary education, African policymakers are now considering making secondary school free, but little is known about the private and social benefits of free secondary education. We exploit randomized assignment to secondary school scholarships among 2,064 youths in Ghana, combined with 12 years of data, to establish that scholarships increase educational attainment, knowledge, skills, and preventative health

behaviors, while reducing female fertility. Eleven years after receipt of the scholarship, only female winners show private labor market gains, but those come primarily in the form of better access to jobs with rents (in particular rationed jobs in the public sector). We develop a simple model to interpret the labor market results and help think through the welfare impact of free secondary education.

\author{
Esther Duflo \\ Department of Economics, E52-544 \\ MIT \\ 77 Massachusetts Avenue \\ Cambridge, MA 02139 \\ and NBER \\ eduflo@mit.edu \\ Pascaline Dupas \\ Department of Economics \\ Stanford University \\ 579 Jane Stanford Way \\ Stanford, CA 94305-6072 \\ and CEPR \\ and also NBER \\ pdupas@stanford.edu
}

Michael Kremer

University of Chicago

Kenneth C. Griffin Department of Economics

1126 E. 59th St.

Chicago, IL 60637

and NBER

kremermr@uchicago.edu 


\section{Introduction}

Following the widespread adoption of free primary education in low-income countries and the subsequent surges in primary school enrollment rates, policymakers' attention has shifted to secondary school. The U.N's new Sustainable Development Goals call for “... free, equitable and quality primary and secondary education leading to relevant and effective learning outcomes". In Ghana, the setting of this study, debates about whether secondary education should be free were central in the last four presidential elections. Secondary education is expensive and making secondary school free generates a transfer to households sufficiently well off to send their children to secondary school in any case. Offsetting these costs are the presumed benefits of secondary education for all those unable to afford it. Surprisingly, however, rigorous evidence on the private and social welfare effects of free secondary education remains scarce. We shed light on this debate by providing experimental evidence of the effects of scholarships for secondary school on a range of outcomes over 12 years.

To do so, this paper answers three questions. First, we assess the extent to which free secondary education would induce more children to attend secondary school and investigate who are the marginal children. Second, we provide estimates of the extent to which access to secondary education increases learning (despite the weak preparation provided by many primary and middle schools and the often-questioned quality of existing secondary schools), and has positive effects on life outcomes such as fertility, female empowerment, technology adoption, and civic knowledge and participation. ${ }^{2}$ Third, we examine the key question of whether free secondary education would generate either private or social labor market gains. It is not obvious it would, given that education levels in poor countries are already high relative to the historical benchmarks for much richer economies (Pritchett, 2018). ${ }^{3}$ Moreover, there is rationing of government jobs that command rents (Murphy et al. 1991; North, 1990). This means that any private gain may come at the expense of others, and also that rapidly expanding education may be problematic if young people see secondary education as promising access to tertiary education and ultimately a government job, but the number of such jobs is limited. Most youth may then not get the jobs they hope for after investing time and money in their education, and some have argued this could lead to a cohort of "over-educated" young people, frustrated in their aspirations (e.g. Krueger and Maleckova 2003; Heckman, 1991).

\footnotetext{
2 See UNGEI, 2010 and Warner et al., 2012, for indications of strong correlations.

${ }^{3}$ For example, in Ghana average years of education among those 15 years old and above in 2010 was 7.8 , equal to the level in the UK in 1970, even though the GDP per capita in Ghana in 2010 was less than a fifth that of the UK in 1970.
} 
Access to senior high school in Ghana has historically been limited based both on a gateway exam administered at the end of grade 8 , which only roughly $40 \%$ of junior high school entrants pass, and by annual tuition fees, corresponding to about $20 \%$ of GDP per capita. ${ }^{4}$ In this project, we generated experimental variation in the cost of secondary school by providing secondary school scholarships to some randomly selected youth in Ghana, while keeping educational requirements the same.

In 2008, full scholarships were awarded to 682 adolescents, randomly selected among a study sample of 2,064 rural youth who had gained admission to a public high school but did not immediately enroll because they were not able to pay the fee. Follow-up data were collected regularly until 2020, when these youth were on average 29 years old. By 2019, we had a minimal attrition rate (under 6\%). Our last round of data collection took place between June and September 2020, which gives us the opportunity to shed light on the impact of secondary education on labor market outcomes during the COVID-19 crisis.

Scholarships increased educational attainment. While $44 \%$ of non-winners were eventually able to obtain a secondary education, winners were 27 percentage points $(60 \%)$ more likely to do so, and they received 1.25 more years of secondary education than non-winners on average. Given enrollment rates absent scholarships, back of the envelope calculations suggest that if free secondary education were to become universal, for every additional year of education induced by the subsidies, the government would be paying for seven (i.e., 6 infra-marginal years for each extra year). ${ }^{5}$

The increase in education translated into an increase in cognitive skills and knowledge. Five years into the study, scholarship winners scored on average 0.16 standard deviations higher on a series of practical math and reading comprehension questions modelled on the PISA. Winners were also more knowledgeable about national and international politics and more likely to know and use modern technologies. Winners were also more likely to have ever enrolled in tertiary education by 4.4 percentage points on a base of 15.4 percent in 2019 (+29\%). These effects are concentrated among women, implying that while the marginal boys induced to attend secondary school by the scholarship were very unlikely to make it to tertiary education, marginal girls induced to attend secondary school made it to tertiary education at almost the same rate as inframarginal girls who would have attended secondary school without scholarships.

\footnotetext{
${ }^{4}$ A complete senior high school education, currently three years, would cost about 70\% of GDP per capita, when additional clothing, exam and material fees are included.

5 The ratio becomes more favorable if the prospect of secondary education induces extra years of junior high school and increases the secondary school entry exam pass rate.
} 
Female winners also reduced their fertility. By age 22 (in 2013), women who had received a scholarship were 7.0 percentage points less likely to have ever been pregnant - a 14.6\% drop compared to the rate in the comparison group (47.9\%), an effect that persisted by age 28 .

Scholarship winners obtained better jobs, but these private benefits seem to reflect in large part access to rationed formal sector jobs. The clearest impact we see on the labor market is that the scholarship increased the odds of females being public-sector employees (often teachers or nurses) by 4.1 percentage points (or 65\%) in 2019. Wage premia and other perks for public sector jobs in Ghana are high, like in many other low- and middle-income countries, particularly for those with tertiary education, both in our data and in other work (Aryeetey and Baah-Boateng, 2016; Barton et al., 2017).

The earnings data is noisy and censored by the fact that some youths are still enrolled in tertiary as of 2019. Up to 2019, we did not observe any impact on average earnings. However, some marginal jobs proved to be protective during the 2020 COVID-19 crisis: women in the treatment group earned 59\% more in April 2020 (when Ghana had shut down to avert the first wave) than women in the control group. Treatment men, however, did not fare better than those in the control group during the COVID-19 slowdown.

Even allowing for the difficult macroeconomic conditions that Ghana experienced around the time our study sample graduated, it is clear there is a substantial gap between actual labor market impacts and the stated expectations of students and their parents. At baseline in 2008, students and parents correctly understood that the key labor market benefit of secondary education would be to open up public sector positions that require tertiary education, but they dramatically overestimated the probability of obtaining public sector positions. At baseline $70 \%$ of students thought they would be a government employee or a teacher (a profession largely dominated by government employees) by the age of 25 if they completed senior high school (Figure 1, Panel A). In reality, only $6 \%$ of those who completed senior high school held these positions by the age of 26 (Figure 1, Panel B), and 8\% by age 28. This misperception could potentially lead to distortions in the amount and type of education individuals chose to pursue.

We interpret these results using a simple model in which households invest in education taking into account the effect of education on non-labor market outcomes, labor market effects in the private sector, and education-based rationing of public sector jobs that carry rents. Households have private information on their child's ability to benefit from schooling but may have gender-specific preferences and beliefs regarding their children and may be heterogeneous in the extent of these gender 
differences. The model is consistent with our findings that 1.) marginal boys who attend secondary school due to the scholarship are unlikely to make it to tertiary education or obtain a public sector job; 2.) marginal girls have very similar rates of obtaining tertiary education or obtaining public sector jobs as inframarginal girls, and 3.) inframarginal girls are less likely to progress to tertiary education or obtain public sector jobs than inframarginal boys. Despite scholarships lowering the threshold perception of child ability above which each household invests in both boys' and girls' education, the pattern of effects can arise through an aggregation effect if almost all household invest in education of talented boys even without scholarships, but households are heterogeneous in beliefs and preferences with regard to girls, with some valuing the non-labor market benefits of education for girls and others only willing to invest in education for girls if they are both very talented and receive a scholarship.

Our results are consistent with the hypothesis that secondary education affects labor market outcomes mostly by helping people compete for jobs that yield rents. However, we cannot rule out that education also generates substantial human capital returns in the private sector. This is because, as the model highlights, the highest ability workers in the treatment group may sort into tertiary education and public sector employment, and this selection makes it difficult to assess the treatment effect of education on private sector wages for any given individual.

Our results contribute to a large literature on the impact of education in low- and middle-income countries. There are surprisingly few well-identified studies on the impact of secondary education in this context. We are aware of no randomized controlled trial (RCT) of the impact of post-elementary education, and of only two studies based on regression discontinuities--exploiting admission cutoffs in test scores in Kenya (Ozier, 2018) and scholarship eligibility cutoffs based on a dropout-risk score in Cambodia (Filmer and Schady, 2014). Our approach can be seen as identifying the impact of relaxing financial constraints to obtaining education, while the regression discontinuity approach can be seen as the impact of relaxing academic qualifications for secondary school, and of course the relevant treatment effects may differ (Lang, 1993; Card, 1999). Our paper also contributes to the literature on long term follow up of interventions (Gertler et al, 2014, Blattman et al, 2020, Evans and Ngatia 2020, Banerjee et al., 2020, Hicks et al, 2020). We show that in this setting, allowing for longterm follow up is essential to get a comprehensive picture of the impact of secondary school. We show in appendix that a state-of-the-art, machine-learning based method to control for a rich array of observables would not have recovered the estimates we find in the paper, suggesting that there is no easy shortcut for the experiment. 


\section{Context}

This section provides background on Ghana's education system and the labor market context throughout our study period, ending with the COVID-19 crisis.

\subsection{Ghana's Education System}

Formal education in Ghana begins with two years of kindergarten, six years of primary school, and three years of junior high school. Primary and junior high school are free and enrollment rates are close to $95 \%$ in primary school and are around $75 \%$ in junior high. At the end of junior high school, students take the Basic Education Certification Examination (BECE) and those with high enough grades qualify for senior high school (SHS). Passing rates are low. Around 70\% of junior high school entrants go on to take the BECE and $60 \%$ of BECE takers pass. Ajayi et al. (2020) find that 30\% of those admitted do not enroll in senior high school the following year. In 2011, government-approved tuition fees for day (non-boarding) students in senior high school were around 500 Ghana cedis per year, a very large sum in a country where the per capita GDP that year was 2400 Ghana cedis. ${ }^{8}$ As of 2010 , girls were 6 percentage points $(20 \%)$ less likely to ever reach senior high school than boys. Some of those who do not enroll in senior high school enroll in Technical and Vocational Institutes (TVIs). ${ }^{9}$

Students who complete senior high school and do well on the senior high school finishing exam (the West African Senior School Certificate Examination or WASSCE) may be admitted to tertiary programs, including degree programs at universities, less prestigious diploma programs, and government training programs. There is a one-year gap between completion of senior high school and admission into university or training colleges. Students who do not score well enough on the exam to secure tertiary admission can retake the senior high school finishing exam any number of times. Tertiary education is expensive. Two government training program, for nursing and teaching, have historically been subsidized through government stipends, though this policy was put on hold in 2014initially precluding youth in our study sample from benefiting from the stipends. The policy was reinstated (though with stipends cut in half) in 2017, allowing some of the students in our cohort to enroll in tertiary education as late as $2017,2018,2019$ or $2020 .^{10}$

\footnotetext{
${ }^{8}$ See http://www.statsghana.gov.gh/docfiles/GDP/EconomicPerformance_2011.pdf

9 TVI students do not have to take any core academic classes and cannot go on to tertiary. TVIs are a relatively minor part of Ghana's education system, with less than $10 \%$ the enrollment of senior high school. In 2008 , there were 43,592 fulltime TVI students compared to the 486,085 senior high school students (MoE Ghana, 2008).

${ }_{10}$ Between the 1980s and 2013, the government paid allowances large enough to cover all fees to all students enrolled in nursing and teacher training programs, making them effectively fully subsidized for those admitted, and admissions in the programs were capped via a quota system. Both the allowances and the quotas were removed in 2014, taking into effect
} 
These two tertiary programs open the door for the most accessible public sector jobs for the population in our sample. As in many low- and middle-income countries, Ghana has very high premia for public sector positions, particularly those requiring tertiary education. Finan et al. (2015) find a wage premium of at least 59\% in Ghana, using the 2013 STEP Skills Measurement Survey. Note that public sector jobs provide substantial benefits beyond higher wages because they provide a great deal of job security and because they typically carry substantial benefits.

\subsection{The Macroeconomic Context}

The effects we measure should be interpreted as conditional on the macro-economic context (Rosenzweig and Udry, 2020). Our study participants began senior high school in the 2008/2009 academic year at the earliest. Most participants who completed senior high school did so and entered the labor market in July of 2012, and our last follow-up survey was administered in 2020. Ghana had strong macro-economic performance through the first quarter of 2012, when GDP growth reached an all-time high of $25.0 \%$, but between 2012 and 2016, GDP growth fell each year, reaching a fifteenyear low of 3.6\% in 2016. It rebounded in Q2 of 2017 and was strong through 2019.

The government changed their secondary and tertiary education policy during our study period. Starting with the school year 2009/2010, the government shortened the length of senior high school from 4 years back to 3 years (what it was before 2007). Our study participants were thus the last cohort (2008/2009) enrolled in the four-year program. As a result, most of our participants graduated in a double cohort with the students who had enrolled a year later, potentially making it more difficult to quickly enter tertiary education.

Government policies affecting the labor market for educated youth entering the labor market also began to shift in 2012. In 2008, the government wage bill was $11.3 \%$ of GDP, which was the highest of the 12 West African countries surveyed by the World Bank. The Ghanaian government enacted a new salary scale for government employees in 2012, which raised the government wage bill by $38 \%$ in one year (IMF, 2012). In 2015, the ballooning wage bill forced the Ghanaian government to accept an IMF loan. As a condition of the loan, the government was required to impose a net hiring freeze on government employment outside health and education departments. The net hiring freeze ran through most of the period in which we collected data and ended in April 2019.

for the school year starting in September 2014. Our study cohort graduated from SHS in June 2012 and the earliest they could have applied for tertiary was Fall 2012 for a September 2013 start-but given the quotas, having to wait at least two years before getting admission was common, thereby the reform directly affected our study cohort. The government that was elected in December of 2016 brought back the allowances and quota system in August 2017. 


\subsection{COVID-19 in Ghana}

The government of Ghana adopted strict measures in response to COVID-19 on March 15, closing schools, banning all social gatherings, and closing international borders. A 3-week lockdown restricted the activities and movements of people in the urban areas of Greater Accra and Kumasi for most of April 2020. Social distancing and regular disinfection protocols were put in place in markets. By end of July, Ghana's Trades Union Congress (TUC) estimated that 100,000 jobs had been lost in the formal sector and 400,000 in the informal sector. ${ }^{11}$ Schools did not re-open until January 2021.

\section{Data and Sample Characteristics}

This section describes our sample, the experimental design and the data collection.

\subsection{Sampling Frame}

The sample frame was constructed as follows. First, 54 rural districts from five regions were included in the study. ${ }^{12}$ Across these 54 districts, we selected 177 publicly funded senior high schools (SHS) accepting only day (i.e. non-boarding) students. ${ }^{13}$ These represented about $60 \%$ of all SHS in the selected districts as of 2008 (and about $25 \%$ of all SHS in the country). They are all co-ed, and typically have over 1,500 students, with an average pupil-teacher ratio of 22. Within each selected SHS, all students officially admitted into the senior high school as of October 2008 were considered for eligibility.

Students needed to satisfy the following eligibility criteria: (1) To have successfully passed the BECE exam and have been placed into one of the 177 study SHS by the Computerized School Selection and Placement System (CSSPS) ${ }^{14}$; (2) To have attended a junior high school in the same district (referred to as "in-district students") as the SHS they were admitted to; (3) To have not yet enrolled in any SHS (verified through school and home visits) by October 2008 (the school year had started in September).

\footnotetext{
11 https:/ /www.theghanareport.com/covid-19-has-rendered-500000-people-jobless-in-ghana-tuc/.

12 At the time, there were only 10 regions in Ghana. The three Northern regions and the Volta region were not selected because the Government of Ghana already ran a scholarship program in those regions at the time. Greater Accra was excluded given our focus on poorer areas. We sampled districts from the remaining five regions.

${ }^{13}$ We focused on day students for budget reasons and because as senior high school becomes more common, we expect more students to be attending day schools.

14 The CSSPS is a centralized, merit-based admission system, which is based on the deferred-acceptance algorithm of Gayle and Shapley (1962) (Ajayi, 2013).
} 
We surveyed 2,246 students eligible for the study and asked them why they had not enrolled. 95\% cited financial difficulties as the main reason, 2\% cited pregnancies and 3\% cited a variety of other reasons such as being injured, having a job or not liking the school they were placed in.

In early January 2009, we called back the 2,246 eligible students to assess whether they had enrolled or intended to enroll in a senior high school for the second term of the 2008-2009 school year. A total of 182 students who either had enrolled or intended to enroll in the immediate term were dropped from the sample prior to randomization. The scholarship program was only announced to students, headmasters, and surveyors later, so students could not have strategically changed their answer based on the potential to receive scholarships. The final study sample is thus composed of 2,064 individuals (1,028 males and 1,036 females). Among females, 746 had taken the junior high school finishing exam in 2008 and 290 had taken it in $2007 .{ }^{16}$

\subsection{Scholarship Program}

The scholarship program was implemented by Innovations for Poverty Action (IPA) in Ghana, in partnership with Senior High School staff, and the Ghana Education Services, the implementing arm of Ghana's Ministry of Education.

The scholarship covered full tuition and fees for a day student for four years. It was paid directly to the school and covered the entire school bill. A typical bill for a day student is comprised of three items: government approved fees which are applied for all schools, PTA (Parents-Teachers Association) dues, and other levies and supplies, including exam fees. The latter two costs are schoolspecific. In addition to paying school fees, the scholarship also included payment for the secondary school exit exam (WASSCE). Students who received the scholarship were only responsible for the cost of school materials, transportation to school, and school meals. The total amount paid by the scholarship program varied slightly across courses and schools but averaged approximately 1,921 Ghana cedis (in 2016 GHX terms) per student who completed senior high school. This corresponds to around USD480.

Winners were notified by phone in January 2009 and encouraged to immediately report to their "placement" SHS (the school where they had been placed into based on their performance on the junior high school finishing exam). SHS Headmasters were informed of the names of scholarship

\footnotetext{
16 To ensure we had enough eligible girls in the sample, we had to include girls who had graduated from junior high school in July 2007 and had gained admission into one of the 177 sampled senior high schools one year prior to the rest of the sample but had still not enrolled as of October 2008.
} 
winners by phone and received an official letter from the Director-General of the Ghana Education Service and IPA with details on the scholarship scheme. All schools agreed to participate. Scholarship students typically accounted for less than $1 \%$ of a cohort in the school.

Enrolling by the start of the second term did not make our scholarship winners particularly unusual, as it is very common for schools to have students enroll late. Ajayi et al. (2020) show that only 44\% of students who eventually enroll do so by week 7 of the academic year. Students on the waitlist are notified late in Term 1 if those initially admitted have not reported and can be replaced.

\subsection{Data}

We use three main data sources: a baseline survey, an extensive follow-up survey administered in person after 5 years, and "callback" surveys (shorter phone surveys) administered almost yearly.

\subsubsection{Baseline Survey}

In November and December of 2008, prior to selecting the students for the scholarship, a baseline survey was administered to the youth themselves as well as to one of their guardians, most commonly the mother. The surveys included questions on perceptions of education, guardian literacy, values and beliefs, as well as modules on members of the household, household living conditions, and assets. After the survey, each student received a basic (non-smart) mobile phone with a sim card and assigned phone number.

\subsubsection{Randomization}

The final study sample of 2,064 youths was stratified by district, senior high school, junior high school, gender and BECE year. A third of students within each stratum (682 in total) were assigned to the "treatment group" (a scholarship) while 1,382 students were assigned to the "comparison group" (no scholarship).

\subsubsection{Sample Maintenance and Attrition}

To enable high follow-up rates, mobile phones were distributed at the onset of the study to every youth, and study participants were sent mobile phone credit worth about USD1 twice a year, as an incentive for them to keep the phone number we had on file active. Once a year, we attempted to reach all respondents in order to update their contact information. If they could not be reached over the phone, we attempted to find them in person by going to their home area. Table A1 presents survey rates across years. In 2017, 9 years after the start of the study, we were able to reach and interview, in 
phone or in person, $95.4 \%$ of our study sample in a few months. In 2019, 11 years after the baseline, the tracking rate was $93.9 \%$. This is remarkably low attrition for a longitudinal study of this kind, particularly for a young-adult, mobile population. Other successful longitudinal studies in low- and middle-income countries achieved 81\% retention over three years (South Africa; Lam et al., 2011), or 95\% (at the household-level) over five years (Indonesian Family Life Survey; Thomas et al., 2002). Studies that deal with attrition by doing intensive tracking on a random subset of the "hard to find" subsample and then reweigh have obtained 91\% over seven years (Kenya; Duflo et al., 2015), 84\% over ten years (Kenya; Baird et al. 2017), and 84\% over twenty years (Kenya, Hicks et al. 2020).

Attrition is not differential by treatment group until 2017. During the 2019 survey round, the refusal rate increased from $1 \%$ to $2.5 \%$ in the control group, while it remained unchanged in the treatment group. This generates a small discrepancy in survey rates across arms, driven by males: male scholarship winners were 2.5 percentage points more likely to be surveyed than non-winners, on a base of $93.1 \%$. The non-winners who refuse the survey appear somewhat negatively selected, ${ }^{17}$ suggesting that this differential attrition may if anything lead us to underestimate treatment effects for males when we focus on the 2019 wave. Attrition in 2020 is somewhat larger because we could not do in-person tracking due to COVID-19. We successfully surveyed $84 \%$ of respondents on the phone. Attrition was 4.9 percentage points smaller in the treatment group than in the control group. Given this, we focus on 2019 as our "main" results, but we note that the patterns of results are identical in the 2020 data, with the exception of the earnings data we explicitly discuss.

\subsubsection{Detailed In-Person Follow-up Survey (2013)}

A detailed in-person follow-up survey was conducted from April to August 2013. For many study participants, this follow-up survey fell in the gap year between the end of secondary high school in July 2012 and potential enrollment in tertiary education in September 2013 (see footnote 10). The survey included modules on schooling, occupation, cognitive skills, labor market expectations, health and fertility, among other things. Most of these modules were fairly standard and adapted from wellknown surveys such as the Demographic and Health Surveys.

The cognitive skills module included reading comprehension questions, as well as applied math questions (e.g. profit calculations, reading and interpreting a bar chart, etc.). There were 17 questions, modeled on the OECD PISA (Program for International Student Assessment) exam, tailored to the

\footnotetext{
17 Regressing the 2017 value for "total years of education" on "refused 2019 survey" yields a coefficient of -1.64 (pvalue $=0.03$ ). For "total earnings in the past 6 months" the coefficient is -662 GHX (p-value 0.15).
} 
Ghana context by the research team with inputs from the Assessment Services Unit (ASU) of the Ghana Ministry of Education.

\subsubsection{Yearly Callback Surveys}

Yearly mini-callbacks were conducted between 2008 and 2014 to update respondents' contact information and basic outcomes (education status, fertility). Starting in 2015, the callbacks included a 30-minute survey on major life outcomes, specifically: tertiary education, fertility, partners, labor market activity, as well as year-specific questions (e.g. in the 2017 callback we asked about voting behavior in the presidential election of December 2016). The last callback was conducted between June and September 2020. In addition to a (somewhat shortened) regular module on life outcomes, we also included questions specifically related to COVID-19.

We have data on many outcomes and over multiple years, which raises the issue of multiple inference. We deal with this by constructing summary indices and by presenting in appendix table A2 the sharpened q-values controlling for the false discovery rate (the expected proportion of rejections that are Type I errors) for p-values below the 0.1 threshold (Benjamini, Krieger, and Yekutieli, 2006).

\subsection{Characteristics of Study Sample}

Table 1 presents key summary statistics on the study sample and baseline balance. Appendix Table A3 presents a few additional characteristics. This data comes from baseline surveys administered to the respondents and their guardians in Fall 2008. As a test for balance, we show mean differences across groups for a battery of outcomes. Specifically, we run regressions of the form:

$$
Y_{i}=\alpha_{i}+\beta T_{i}+\varepsilon_{i}
$$

where $\mathrm{Y}$ is the outcome of interest and $\mathrm{T}$ is whether or not the student won a scholarship. Since randomization was at the individual level, we do not cluster standard errors. For each variable of interest, we show $\hat{\beta}$, the difference between the treatment and control group, and its standard error. We also present the mean outcome in the control group. We show the means and estimate the regressions in the full sample in panel A, and by gender in panels B and C. We show results with region fixed effects and a control for junior high school finishing exam (BECE) score. The results do not change when controlling for the stratification variables (district, senior high school of admission, BECE year) and/or other important baseline characteristics. 
Students were on average 17 years old at the onset of the study. Our study participants come from poor households, which is unsurprising since they are drawn from the financially constrained. Over $40 \%$ of the students lived in households with no male head and $48 \%$ of household heads have only primary education or less, compared to $24 \%$ and $35 \%$, respectively, in Ghana as a whole. Additionally, only $17 \%$ of household heads have reached at least senior high school, compared to $26 \%$ in Ghana as a whole (figures for Ghana as a whole come from Ghana Statistical Services 2010).

Respondents had extremely optimistic beliefs about the returns to secondary education at baseline: the average perceived percentage increase in earnings if one completes senior high school compared to not completing senior high school was $276 \%$ in the control group (Table 1, column 7). These high expected average returns are not driven by outliers: 46\% thought the returns would be at least 100\%.

Panel A of Figure 1 shows that respondents saw a secondary school degree as the gateway to a government job. Over 70\% thought they would be a government employee or in a profession dominated by government employees by the age of 25 if they completed senior high school $(81 \%$ of females and 65\% of males). In particular, respondents often thought they would be a teacher or a nurse, which may be because rural youth interact more with teachers or nurses than with people in other professions requiring secondary or tertiary education.

\section{Impacts on Educational Attainment}

Considerable evidence suggests that participation in primary school is responsive to school fees, but less is known about how secondary school participation respond to direct costs. ${ }^{19}$ This section presents effects of the scholarship on educational attainment and skills. We also provide a back of the envelope estimate of the fiscal costs of a free secondary education policy.

\subsection{Secondary Education}

We estimate the impact of the scholarship on educational attainment using regressions similar to equation (1). In the specifications reported in the text, we include regional fixed effects, and control

\footnotetext{
19 There is however a large literature on conditional cash transfer, which speaks to how secondary education participation responds to indirect costs and incentives. Barrera-Osorio et al. (2007) find that fee reductions increased primary enrollment but find no effect on secondary enrollment. Angrist et al. (2006) find that vouchers for private secondary school increased completion rates. Barrera-Osorio et al. (2011) find effects of CCTs on secondary enrollment. Khandker et al (2013) find that a stipend for secondary education increased enrollment among girls but had no effect among boys. Blimpo et al. (2019) find that secondary school fees elimination increased girls' enrollment by $55 \%$.
} 
for the BECE exam score, though all our results are robust to the inclusion of additional baseline controls. The main results are presented in Figure 2 and Table 2. Additional education outcomes are shown in Table A4.

Seventy-five percent of scholarship winners enrolled in senior high school immediately upon learning about the scholarship, almost four times the enrollment rate in the comparison group (Figure 2). By $2019,70.8 \%$ of the scholarship winners had completed SHS, compared to $43.6 \%$ of the non-winners (Table 2). Thus, while many of those in the control group were eventually able to enroll, scholarships generated a large gap in educational attainment between winners and non-winners.

While the scholarship increased attendance in SHS, it led to a small reduction in attendance in technical and vocational institutes (TVI). In the comparison group, 2.9\% completed TVI as of the 2019 survey while in the treatment group, only $0.9 \%$ had done so.

The scholarship increased the SHS completion rate (the fraction of the entire group - including those that do not enroll - who graduate from SHS) from 38.9\% to $64.7 \%$ among women (a $66 \%$ increase) and from $48.5 \%$ to $76.6 \%$ among men (a 58\% increase). ${ }^{20}$ Figure 3 shows that the effect of scholarships on SHS completion is large and statistically significant at the $1 \%$ level at all quartiles of the initial test score distribution. The graduation rate (the fraction of those ever enrolled who graduate from SHS) is extremely high: $98 \%$ of scholarship recipients who enroll graduate, compared to 95\% of those in the comparison group, with no meaningful difference by gender. ${ }^{21}$

Overall, as of 2019 the scholarship had led to a 1.24 years increase in total years of education on average (Table 2). Quantitatively, for most of the sample, the change is overwhelmingly due to years spent in secondary school. In fact, the scholarship led to a 1.25 years increase in years spent in SHS, which is larger than the increase in total years of education due the substitution away from TVI.

\subsection{Tertiary Education}

As of 2019, 15.4\% of the comparison group had ever enrolled in tertiary education (5.8\% at university, $4.0 \%$ at teacher training colleges, $2.4 \%$ at nursing colleges, and the rest at other professional schools). The treatment effect of the scholarship was an increase of 4.4 percentage points $(29 \%)$ (Table 2), seen

\footnotetext{
20 The lower absolute level of completion rate among women is primarily driven by the fact that about $28 \%$ of the women in the sample had completed junior high school one year prior to the scholarship program (the BECE '07 girls). Among those, take-up of the scholarship was significantly lower, at $56 \%$, compared to $72 \%$ among women who had graduated in 2008 and $79 \%$ among men who had graduate in 2008 .

${ }^{21}$ For this calculation, we use information on whether students had ever enrolled in SHS as of 2019, shown in Table A4.
} 
across all types of tertiary programs. As of 2019, the treatment group was 3.5 percentage points (40\%) more likely to have completed tertiary.

The average tertiary enrollment results conceal important heterogeneity by gender. Treatment effects on tertiary education are concentrated among women. In 2019, female scholarship winners are 7.7 percentage points more likely to have ever enrolled in a tertiary institution on a base of $12.6 \%$, and 4.0 percentage points more likely to have completed tertiary on a base of $7.8 \%$, while the effects on males are small and insignificant. The same pattern is present in 2020 (see column 8 of Table 2 and column 6 of Table A4). The effects could be interpreted as indicating that boys who were likely to be able to eventually enroll in tertiary school were already likely to attend secondary school without the scholarship but that many girls who would have made it to tertiary education were only able to attend secondary school due to the scholarship. Note that the effect on women is large enough that provision of free secondary education led to equalization of the rates of tertiary attendance by gender within our full sample.

While we see significant impacts of the secondary school scholarship on tertiary enrollment and effects are substantial relative to the low base rates, they are small in absolute terms, especially in comparison to expectations. As of 2017 , almost $50 \%$ of the control group and $65 \%$ of the treatment group were planning to apply to go to tertiary, many through the "mature applicant" university admission system, reserved for students above 25 (Table A5). Two years later (2019), only 2\% (3.2\% in treatment group) had done so. Plans were still alive and well, however, with $37 \%$ of the control group and $52 \%$ of the treatment group still planning to apply to tertiary as of 2019 (Table A5). We see a small increase between 2019 and 2020 in having ever enrolled in tertiary, suggesting that there will likely be a trickle of new tertiary enrollees in the sample over a few more years.

The results so far suggest that marginal boys (those induced to complete senior high school by the scholarship) struggle to move from senior high school completion to tertiary enrollment relative to infra-marginal boys (those who could finish senior high school without a scholarship). Assuming that the treatment effect on tertiary enrollment is due to marginal students, only $4 \%(0.010 / 0.281)$ of boys induced to complete secondary school by the scholarship went on to tertiary education compared to $38 \%(0.184 / 0.485)$ of inframarginal boys. This is not because marginal boys are drawn from a lower part of the initial score distribution (compliers have similar BECE scores than always takers-see Appendix B for more details). 
Marginal girls, however, are as likely to move on to tertiary as inframarginal girls. Of the girls induced to complete SHS by the scholarship, 30\% (0.077/0.258) went on to tertiary education. For inframarginal girls, the fraction of SHS graduates who eventually enroll in tertiary is $32 \%$ $(0.126 / 0.389)$, somewhat lower than for inframarginal boys.

In Section 7, we present a model that is consistent with the findings that inframarginal boys are somewhat more likely to progress to tertiary than inframarginal girls, that marginal boys are unlikely to make it to tertiary education, and that marginal girls perform much better than marginal boys and almost as well as inframarginal girls.

Column 7 of Table 2 shows current enrollment status as of 2019. Remarkably, scholarship winners were still more likely to be enrolled in formal study - this is driven entirely by females, who are 2.9 percentage points more likely to still be studying, on a base of $3.5 \%$, a very large proportional gap. Even in 2020, scholarship winners were still 1.9 percentage point (43\%) more likely to be enrolled in a tertiary program than the control group (although only marginally significant at the $10 \%$ level) and this time we see similar point estimates for male and women (Table A4 column 5). This has implications for the estimates of labor market impacts, something we discuss in detail in Section 7.

\subsection{Estimating the Fiscal Cost of Free Secondary Education}

Using the responsiveness of secondary school participation to school fees we can estimate the fiscal cost per additional year of enrollment from making secondary education free. Given the findings above, and the distribution of junior high school exit exam scores, we estimate that in the absence of incentive effects on primary school students, making secondary education free could require paying for seven years of secondary school for every additional year of education generated by marginal students. To see the logic, note that on average, scholarship winners spent 3.08 years in senior high school, while non-scholarship winners spent 1.83 years in senior high school, a difference of 1.25 years. Therefore, within our sample, the scholarship paid for 3.08 years of education for each 1.25 additional years of education. With a few assumptions, we can estimate the effect of a nation-wide free senior high school policy using these results. We assume that $60 \%$ of qualified students enroll in senior high school by the beginning of Term $2,{ }^{23}$ and assume that they would graduate under the policies prevailing at the time of the study, without free secondary education. We assume that the $40 \%$

\footnotetext{
${ }^{23}$ Ajayi et al. (2020) find that 44\% enroll in the first 6 weeks, and our own sampling data show that $8 \%(182 / 2246)$ of those who have not enrolled in the first 6 weeks enroll by the beginning of Term 2 . This yields $0.44+0.66 * 0.08=48 \%$ enrollment rate by the beginning of Term 2. Ajayi et al. (2020) find that $70 \%$ have enrolled by the end of Term 2 . To be conservative, we use $60 \%$, roughly the midpoint between these two estimates.
} 
of qualified students who do not enroll by the beginning of Term 2 behave like our sample (i.e. they obtain on average 1.84 years of secondary education without financial help and 3.09 years when it is free). With these assumptions, universal free SHS education would require paying for $0.6 \times 4$ years + $0.4 \times 3.09$ years $=3.6$ years $/$ student, using the old standard of 4 years, but this would generate only $0.4 \times(3.08$ years -1.83 years $)=0.5$ years/student. Therefore, a free senior high school policy would pay for 3.6 years of education for each additional 0.5 year of schooling attained and the fiscal cost per additional secondary school graduate would be approximately $\$ 3,680 .^{24}$

Note, however, that the promise of free secondary school for students who pass the junior high school finishing exam may also incentivize more financially constrained students to study harder in earlier stages of education, allowing more of them to pass the exam and qualify for senior high school (for some evidence of such incentive effects, see Kremer et al. (2009) at the upper primary level in Kenya, and Lajaaj et al. (2018) at the tertiary level in Colombia.) In Ghana this is likely an important margin, since as of 2014 only about $40 \%$ of those who start junior high school pass the finishing exam. ${ }^{25}$

Targeting scholarships to students with characteristics that predict lower senior high school enrollment conditional on qualifying based on merit (such as students with lower incomes and female students) could increase the ratio of marginal to infra-marginal expenditure and reduce any regressive effects of scholarships for senior high school.

\section{Knowledge, Skills, Fertility, Marriage, and Health}

Some have expressed concern about whether increases in access to education will lead to increases in learning, given the quality of schools (Pritchett, 2001). Knowledge and education are correlated in non-experimental data, but this may reflect the correlation between existing skills and enrollment. In this section, we document significant improvement in cognitive skills.

\subsection{Learning Outcomes}

\footnotetext{
${ }^{24}$ Current estimated cost of a 3-year scholarship (\$400) divided by expected additional graduates from one scholarship (which is the estimated treatment effect of a $27.2 \%$ increase in graduates multiplied by $40 \%$ of qualified students who do not enroll on their own by the beginning of Term 2).

${ }^{25}$ If one assumes that the promise of free secondary education would lead one quarter of students who currently do not pass the primary school leaving exam to pass, the ratio of years of education paid for to marginal years of education would fall from 7.2 to 4.9 , and the fiscal cost per extra graduate falls to $\$ 2,609$.
} 
Impacts on cognitive skills and knowledge are presented in Table 3. These results are based on oral tests administered as part of the 2013 in-person survey. Thus, these tests provide the effect after most study participants had completed or stopped going to senior high school but before participants had a chance to enroll in tertiary education.

In the full sample, scholarship winners score 0.157 standard deviations higher (we see gains both in math and in reading, see Table A6). The point estimates vary little with how selective the school is and effects are significant at the 5\% level for the second and fourth quartiles of the initial test score distribution (Figure A1). The point estimates are larger for females (0.194) than for males (0.113), although the difference is not statistically significant. Note that there are very large differences in scores by gender in the control group, with men (who have 0.5 more year of education on average) vastly outperforming women. Thus, despite very large gains, female scholarship winners are barely on par with male non-winners and far behind male winners in learning outcomes. ${ }^{26}$

\subsection{Connectedness and Technology Adoption}

Besides impacts on cognitive skills, in 2013 scholarship winners scored higher on a series of questions related to current political affairs. They were also more likely to report engaging with the media, and more likely to know how to use the internet (the second significant only at the $10 \%$ level, see Table 3). These gains persisted: in 2016, they scored higher on an ICT/Social media adoption index (marginally significant at the $10 \%$ level, see description of indices in Table 3 notes). Regular internet usage remains higher for the treatment group in 2019, particularly among women.

Turning to other technologies, we find that the scholarship accelerates adoption of bank accounts among women - here again, helping reduce the gender gap. However, we do not see any significant effects on adoption on fertilizer use for the small fraction involved in farming.

\subsection{Civic Participation}

Experimental evidence of the impact of education on civic participation at the micro-level is rare. Our data collection period spanned two presidential elections (2012 and 2016), and two district assembly elections, for which our sample was old enough to vote. We present results on voting behavior in

\footnotetext{
${ }^{26}$ We show in appendix some evidence that the test scores gains are not due to students in treatment group working harder on the tests than those in the control group. We find no difference on IQ, as measured by Raven's matrices and digit span (which should not depend on education but do depend on concentration and effort) (Table A6). And while the enumerator rated the winners as 5pp more likely to have exercised full effort (Figure A2), the difference is too small to account for the whole difference in test scores, given the correlation between effort and test score.
} 
Table 4. We find no effect of the scholarship on voting propensity, whether in presidential elections, where the turnout is very high overall, or in district assembly elections, where the turnout is much lower. This is in direct contrast with the findings in Sondheimer and Green (2010), who exploit three small-scale randomized education programs in the United States to study long-run impacts on voting behavior and found large positive impacts from education on voting. However, previous studies have found evidence that such influence of education level on political participation is not as clear in low income countries, which is consistent with our findings (see Friedman et al., 2016; Blaydes, 2006, Campante and Chor, 2012).

\subsection{Fertility, Partners and Health Behavior}

Table 5 presents results on fertility and marriage and show consistent patterns over a wide range of outcomes, especially for women.

Scholarships greatly reduce pregnancies and unwanted pregnancies for women. By 2013, women in the scholarship arm were 7.0 percentage points less likely to have ever been pregnant (on a base of $47.9 \%$ in the control group). Because the great majority of first pregnancies are reported to be unwanted, the fertility decline is almost exclusively a decline in unplanned, out-of-wedlock pregnancies. As shown in Figure 4, the fertility effect is sustained until our most recent survey. These results are consistent with those of a randomized experiment that reduced the cost of access to upper primary school in Kenya and found that the onset of childbearing was also delayed, with no-catch up in the three years following school exit (Duflo et al., 2015).

The finding that the gap in childbearing between treatment and comparison groups persists once the majority of scholarship winners are out of school suggests that the mechanism is not an "incarceration effect", preventing fertility for a few years while in school (Black, Devereux and Salvanes, 2008). We have collected data that sheds light on the importance to our respondents of the mechanisms most discussed in the literature, namely (1) increase in the opportunity cost of bearing and raising children (Becker, 1991); (2) the ability to make better choices thanks to better decoding of information (Rosenzweig and Schultz, 1989); (3) changes in desired fertility; and (4) changes in the type or preferences of the partner.

Consistent with channel (1), we show below that female winners are more likely to have contract employment than female non-winners, which presumably increases the opportunity cost of a child. Consistent with channel (2), we find large increases in learning for both men and women (Table 3 and 
A6), and an increase in the adoption of preventive health behavior (Table A7, column 2). There is no evidence for channel (3) in our sample (Table A7, column 1). Finally, we find significant effects on partners (Table 5). First, fertility changes coincide with changes in co-habiting behavior, starting with a delay in cohabitation. By 2016 (age 25 on average), treatment women were 12.1 percentage points (24\% of the control mean) less likely to report having ever lived with a partner. As of 2019, they are 6.2 percentage points ( $\mathrm{p}$-value 0.067 ) less likely to be married or cohabiting (compared to a base of $47.5 \%$ in the control group).

The effect on the education of partners is somewhat complicated to interpret since there are differential match rates across treatment and control groups, but it is striking that the effect seems to be of the opposite sign for females and males (although the effect is only significant at the $10 \%$ level for females). Female scholarship winners are significantly more likely to have partners with tertiary education ( $+7.1 \mathrm{pp}$ on a basis of $19.5 \%$ ), while the opposite holds for men: while only $7.2 \%$ have a partner who has tertiary education in the control group, this reduces further by a significant 5.1pp in the treatment group.

Besides this impact on partner characteristics, we see few changes in fertility and marriage behavior for men, although it is worth noting that men marry later and that parenthood is likely measured with much more error for them: since many pregnancies are out of wedlock and not all of them lead to shotgun marriages, it is possible that male respondents under-report births they may have been responsible for. One clear impact on male scholarship winners is that they are more likely to still be living with their parents (+ 7.8 percentage points, or 30\% of the control mean, in 2019), which may be related to their labor supply decisions.

Column 8 of Table 5 shows results on child mortality. We are somewhat under-powered for this outcome and the effects are not significant, but point estimates suggest a fairly large decrease in child mortality among female scholarship winners. These results are consistent with the finding, shown in Table A7, that winning a scholarship leads to reports of safer health choices. In 2013, scholarship winners reported adopting more preventative health behaviors (0.105 increase on an index covering three categories: handwashing with soap, anti-malarial bed net use, and mosquito repellent use). They also report less risky sexual behavior (-0.047 SD on an index of 12 questions).

In the 2020 callback, however, we see no difference between winners and losers in knowledge of COVID-19 or in the adoption of social distancing practices (columns 5 and 6 of Table A7). This is possibly because awareness was very high for everyone, given the salience of COVID-19. 


\section{Labor Market}

This section discusses labor market impacts, focusing on our last two rounds of data (2019 and 2020), The 2017 results are reported in Table A8. The long-run follow up is critical to capture the effects on public sector employment, which requires tertiary education and often a waiting period. ${ }^{29}$ Indeed, throughout most of our labor market survey period (2015-2020) there is entry to and exit from tertiary education (as discussed in section 4). Both are significantly more likely in the treatment group, so selection into the labor market is differential across arms, and across years within arms. Year 2019 is our last "normal" year. The year 2020 allows us to shed light on the impact of secondary education on resilience during the pandemic.

\subsection{9 results}

Impacts on labor outcomes as of 2019 are presented in Table 6. We see no impact on labor force participation (having worked for pay in the past 6 months), but the type of employment differs between treatment and control groups. Scholarship winners are 3.9 percentage points more likely to be a salaried employee with a contract ( $\mathrm{p}$-value 0.008$)$, a relatively rare outcome overall $(8.4 \%$ in the control group). Relatedly, scholarship winners are 3 percentage points more likely to have jobs with benefits ( $\mathrm{p}$-value 0.052). Self-employment is lower among scholarship winners, but not significantly.

Winning a scholarship substantially increases the chance a woman eventually obtains a public sector job, but consistent with the tertiary education results, it does not do so for men. Looking at the control group, 6.3/38.9 or 16 percent of inframarginal women obtain public sector jobs. Female scholarship winners were 4.1 percentage points more likely to be public sector employees. This implies that $16 \%$ (4.1/25.8) of marginal women ended up getting a public sector job, the same figure as among inframarginal women. $\quad 19 \%(9.2 / 48.5)$ of inframarginal men obtain public sector jobs. There is no significant effect of the scholarship on men obtaining public sector jobs, which means that we cannot reject the hypothesis that none of the marginal men obtained a public sector job.

The estimate of the total impact on earnings is 37 shilling ( $3 \%$ of the control group mean), a very imprecise estimate $(95 \%$ CI $[-10 \%,+15 \%$ of the control group mean], p-value 0.65$)$. We cannot reject that returns are either zero or high compared to standard estimates of Mincerian returns. For example,

${ }^{29}$ All graduates of Ghanaian tertiary institutions are required to serve one year in the National Service. In the National Service, the graduate will work (usually for the government, but occasionally for a private company) for a year and receive a monthly stipend from the government. See https://nss.gov.gh/nss-faqs 
Duflo (2001) reports returns to education ranging from $6.8 \%$ to 10.6\%. There are several reason for this imprecision. A quarter of our sample is self-employed and hence their income is subject to stochastic shocks and seasonal fluctuation. Moreover, self-employment income is particularly subject to measurement error (de Mel et al., 2009). Finally, income is highly skewed.

In addition, estimated short-run returns may underestimate long-run returns for two reasons. First, differences in educational enrollment between winners and losers may bias estimates. Section 7 derives bounds based on our model. Second, if education and experience are complementary (e.g. Yamauchi, 2004), effects on lifetime income will exceed short-run effects.

Public sector wageworkers in our sample earn 3,335 GHX in 6 months on average, which is above the 85th percentile of the sample's earnings distribution. However, a quantile regression (not shown) cannot reject the hypothesis of no effect of the scholarship, even on the $90^{\text {th }}$ percentile of earnings. This is because the wages of the public sector wageworkers are offset by the control group having more self-employed in the higher deciles of earnings. This is consistent with the model we outline below, in which the scholarship increases the chance recipients obtain government jobs which provide security and allow lower effort but may well offer lower earnings in a particular period than selfemployment.

One factor that may limit the impact of jobs on earnings is that scholarship winners do not appear to be willing or able to move for jobs: the probability of having migrated and settled to an urban area is the same among the two groups, and modest, at $12 \%$.

\subsection{0 results: COVID}

Table 7 presents labor market results from the 2020 survey round. We control for the specific time at which the survey was done for this analysis, since the survey was spread over three months and the COVID-19 situation was evolving rapidly, with restrictions easing over time. While self-employment increased by 10 percentage points in the control group between 2019 and 2020, both female and male scholarship winners saw a smaller increase, and as a result scholarship winners are 6.6 percentage points $(-19 \%)$ less likely to be self-employed in 2020 (p-value 0.004). Besides this, the treatment effects for men and women scholarship winners seem to have taken very different turns during these times.

Among men, we do not see significant differences between scholarship winners and losers in the probability of having a job with benefits or with a contract, and total earnings in the first half of 2020 are in fact smaller (though not significantly) for scholarship winners. 
In contrast, among women, scholarship winners do much better than scholarship losers during the pandemic. For the first time, we detect large and marginally significant differences in earnings, with women in the treatment group reporting 26\% higher earnings (p-value 0.079) over the past 6 months (recall that the 2020 survey was done between June and September 2020 so the earnings data cover approximately the first half of 2020). Looking at data month by month, we see a particularly large gap in earnings in April, the month most affected by the introduction of severe COVID-19 related restrictions. ${ }^{30}$ Female scholarship winners also benefit from more stable earnings, with a lower coefficient of variation in monthly earnings (p-value 0.092).

\subsection{Aspirations or Frustration?}

While substantial in percentage terms, the increase in tertiary education and in obtaining public sector jobs was much lower than parents or children anticipated at baseline-in fact, we cannot reject that it was null for males. Returns to education in this context fall far short of perceived returns to education, as shown in section 3.4. This suggests that the finding in Jensen (2010) that eighth-grade boys in the Dominican Republic underestimate the returns to secondary school is not general (see also Kaufmann 2014, Benhassine et al. 2015, and Nguyen 2008).

Given that, the question is whether the program generated disappointment and frustration in the years that followed secondary school graduation, especially for males. This does not appear to be true on average, although the evidence does not point towards a large positive effect of education on mental health and well-being either: a satisfaction index (covering life satisfaction, financial satisfaction and a comparison of their life to others) shows a small insignificant negative treatment effect, as does a mental health index (Table A10). A striking result is that, in 2017, among those who have a job, scholarship winners are much less satisfied with it (a decline of -0.196 on a scale that ranges from 1 to 5, p. value 0.02), but also more confident they can get a better one (an increase of 0.071 on an index that ranges from 1 to 5, p. value 0.018). By 2019, satisfaction with one's job remains lower in the treatment group, and scholarship winners are significantly more likely to be actively looking for a job, whether or not they are currently employed, suggesting that they maintain higher aspirations (Table A10). Thus, overall, access to free senior high school does not appear to be associated either with deep frustration or significantly happier lives. Although few graduates have found the jobs that meet their high expectations for education at baseline, their hopes appear to still be alive.

\footnotetext{
30 There is a 35\% increase in March and a 59\% increase in earnings in April (with a p-value of 0.006). By May, the employment and earnings of the control women have recovered and the treatment effects are smaller.
} 


\section{Model}

This section presents a simple model of human capital in a context in which households choose investment in education taking into account the effects of education on non-labor market outcomes, the private-labor market, and the chance of obtaining a public sector job commanding rents that is rationed by education. We use the model to show that heterogeneity among households in genderspecific preferences and beliefs can help explain why marginal girls induced to attend senior high school by scholarships perform well relative to both inframarginal girls and marginal boys in advancing to tertiary education and obtaining public sector jobs while inframarginal boys are more likely to obtain tertiary education and public sector jobs than inframarginal girls. We also use the model to construct bounds on the effect of education on earnings and to argue that private utility returns to education likely exceed gains due to increased average earnings. The model suggests that while much of the private labor market return to receiving a scholarship may come in the form of increased access to public sector jobs and thus be at the expense of those who might otherwise have obtained those positions, we cannot rule out the possibility that the scholarship program had social benefits exceeding its costs.

Subsection 7.1 lays out assumptions on the human capital production process and the labor market. Subsection 7.2 characterizes household decisions on educational investment with and without an education subsidy. Subsection 7.3 investigates the labor market and economic implications of the subsidy and establishes bounds on the rate of return to senior high school.

\subsection{Assumptions}

Timing: At $\mathrm{t}=0$, parents choose whether to enroll their offspring in secondary education. At $\mathrm{t}=1$, offspring are either in secondary education or the labor market. Those who do well enough on their exams at the end of secondary school go on to tertiary education at $t=2$, while others enter the labor market. By $\mathrm{t}=3$, all offspring are in the labor market. Offspring's consumption takes place only when they join the labor market (at $\mathrm{t}=2$ or $\mathrm{t}=3$ ). Households cannot save or borrow.

Endowments: At t $=0$ parents have already worked and have wealth drawn from a distribution $H($. with lower support greater than $c_{c}$ (defined below). Offspring have initial ability drawn from a continuous distribution $G($.$) with support [\underline{a}, \bar{a}]$. (Note that by initial ability we mean anything correlated with the child-specific impact of education that is at least partially observable by parents we are thinking of something broader than just test scores going in to SHS.) Wealth and initial ability are assumed to be independent. 
Human capital production: Households, indexed by $i$, each have one child. Offspring's skill depends on initial ability $a_{i}$, the highest level of education completed $h_{i}$, and a random noise term $\varepsilon_{i}$ : $s_{i}=S\left(h_{i}, a_{i}\right)+\varepsilon_{i} \cdot \frac{\partial s}{\partial h}, \frac{\partial s}{\partial a}>0$ and initial ability and education are complements in the human capital production function, i.e. $\frac{\partial^{2} s}{\partial h \partial a}>0$ (see Heckman and Mosso, 2014; Abbott et al., 2019). The highest level of education can be primary $\left(h_{i}=1\right)$, secondary $\left(h_{i}=2\right)$ or tertiary $\left(h_{i}=3\right)$. Performance on the admissions test for tertiary education is increasing in initial ability, but subject to a stochastic element. All offspring who complete secondary education and qualify for tertiary automatically go on to tertiary education. $\varepsilon$, the error term in human capital production is mean zero, independently and identically drawn from a continuous distribution $E($.$) with lower support of \underline{\varepsilon}>$ $\frac{c_{C}}{A_{h}}-S(1, \underline{a})-\frac{\eta}{A_{h}}$. (Notation in this expression is defined below).

Parent perception of offspring ability: Parents do not observe the actual ability of their offspring, $a_{i}$, they only observe perceived ability, $\hat{a}_{i}$, which is a continuous and strictly increasing function of actual ability, $\hat{a}_{i}=b_{i}\left(a_{i}\right)$ that may vary across households.

Education cost: Denote the cost of secondary education as $c$. Since the treatment group $\left(\boldsymbol{T}_{i}=1\right)$ receives a scholarship its cost, $c_{T}$, is less than that of the control group $\left(\boldsymbol{T}_{i}=0\right), c_{C}$. (We assume that the subsidy is provided only to a small portion of the cohort so examine only partial equilibrium effects).

Production function: Once skill is realized, offspring enter a labor market with three different production technologies: self-employment, working for others in private firms, and the public sector. For self-employment, the production of a single worker is $Y_{h}=A_{h} s+e+\eta$, where $s$ represents worker's skill, $e$ effort, and $\eta$ is an idiosyncratic mean-zero time-varying shock term with lower support $\underline{\eta}$. In the private wage-sector, production is $Y_{p}=A_{p} s+e-f_{p}+\eta$, where $f_{p}$ represents a fixed cost of working in the private sector and $A_{p}>A_{h}$. Finally, in the public sector, production is $Y_{g}=A_{g} s+$ $e-f_{g}+\eta$, where $f_{g}$ represents a fixed cost of working in the public sector. We assume that $S(3, \underline{a})+\underline{\varepsilon}>\frac{f_{p}}{A_{p}-A_{h}}$, which ensures that all tertiary graduates are more productive in the competitive private sector than in the self-employment sector.

Labor market institutions: Self-employment and the private sector are perfectly competitive. Selfemployed workers receive their output and bear risk, while firms in the private sector can perfectly 
monitor workers, so pay a fixed wage (according to skill level) and insure workers. In the public sector, jobs pay rents and positions are rationed by tertiary education (this sector could also be thought of more broadly as a sector that pays a premium over the market wage, where jobs are rationed by education level). We will treat public sector jobs as allocated by a lottery among all those eligible who seek to work in this sector. We focus on the problem facing individual households, and since the scholarship program is small, we will assume that households can treat the probability of obtaining a public sector job as exogenous given their education and skill level.

Wages in the public sector are institutionally fixed at $w_{g}=A_{p} s+\phi-f_{p}$ where $\phi \geq 1 / 2$. Public sector workers thus face no effort incentives and bear no risk.

Utility function: Building on Becker et al. (2018) and Ferreira et al. (2009), we assume parents maximize expected utility:

$$
u_{i}=\ln x_{i o}^{1}+x_{i o}^{2}+\lambda_{i g} E\left[u_{c i}\right]-\frac{1}{2} e_{i}^{2}
$$

where $x_{i 0}^{1}$ denotes household $i$ 's consumption of good 1 at $t=0, x_{i 0}^{2}$ denotes the consumption of good $2, e_{i}$ denotes effort, and $u_{c i}$ denotes the offspring's welfare after they join the labor market. The parameter $0 \leq \lambda_{i g} \leq 1$ represents the household and offspring-gender specific weight parents put on their offspring's welfare. ${ }^{31}$ Gender is indexed by the subscript $g$, where $g=f$ denotes a female and $g=m$ denotes a male. Parents do not face a choice of effort, we use $e_{i}=0$ for simplicity. Moreover, we assume the price of good 1 and that of good 2 are exogenously given, both being 1 . The utility of the offspring follows a similar quasilinear form:

$$
u_{c i}=\ln x_{c i}^{1}+x_{c i}^{2}-\frac{1}{2} e_{c i}^{2}+\gamma_{g} h_{i}
$$

where the last term corresponds to the utility term derived by the offspring from non-labor market impacts of education. $h_{i}$ is the highest level of education completed as defined previously and the coefficient $\gamma_{g}$ is gender-specific and we assume that $\gamma_{f}>\gamma_{m}$ (this is consistent with our empirical results that scholarships reduced unwanted pregnancies and led to higher quality partners for women but had smaller effects for men)

\footnotetext{
${ }^{31}$ We take the possibility of gender differences in parental preference as exogenous for simplicity, but it could also endogenously arise from differences in parents' ability to recoup investments in children's education or gender.
} 


\subsection{Household choice of effort, sector, and human capital}

Given the education choices of all other households, and hence the chance of obtaining a public sector job conditional on obtaining tertiary education, it is possible to solve the optimization problem of individual households backwards, first solving for effort choice within each sector, then choice of sector given skill, and finally parental education choice as a function of wealth, offspring gender, perceived ability, and scholarship receipt. All proofs are presented in Online Appendix A.

Proposition 1: (i) Public sector workers will choose $e^{*}=0$ while self-employed workers and workers in the competitive private sector will choose $e^{*}=1$. (ii) Workers with skill $s>\frac{f_{p}}{A_{p}-A_{h}}$ and no tertiary education will prefer to work in the competitive private sector, while workers with $s>\frac{f_{p}}{A_{p}-A_{h}}$ and tertiary education will apply for jobs in the public sector, as illustrated in Figure 5 A.

\section{Characterizing education choices:}

Define the decision variable $D_{i}$ as equal to 1 if offspring are enrolled in secondary and 0 otherwise. Note that $\widehat{\Delta}_{i}$, parents' perception of the gain in utility to the offspring from enrolling in secondary education, is increasing in offspring's initial ability. The model implies that households have stronger reasons to invest in secondary education the higher their estimate of their offspring's ability.

Proposition 2: (i) Given the education choices of other households, for each household, there exists a gender-specific threshold of offspring's perceived ability, $a_{w}$, above which $D=1$ and below which $D=0$. (ii) $a_{w}$ decreases with the cost of education, all else equal, and thus subsidies weakly increase the share of offspring obtaining education.

\section{Probabilities of tertiary education and public sector employment among marginal and inframarginal students, by gender:}

While at the individual household level education subsidies induce offspring with lower initial ability to enroll in secondary school within each gender, heterogeneity across households could lead to aggregation effects that may make marginal girls, those that only get access to secondary education because of the scholarship, equal or higher ability than inframarginal girls. To see the intuition, recall that households may have gender-specific preferences and beliefs regarding education. Suppose that on one end of the distribution some households value the non-labor market benefits of education for girls, but that other households are so strongly biased against girls that in the absence of a scholarship they do not send any girls to SHS and that with a scholarship, they only send girls with very high initial 
ability. If this latter group of households is large enough, then average initial ability among girls could rise in response to the scholarship. At the same time, if enough households have relatively similar preferences and beliefs across genders and value the non-labor market benefits of education for girls, inframarginal girls may be less likely to go on to tertiary education or obtain public sector jobs than inframarginal boys.

Proposition 3: If households are identical in all aspects but offspring's ability, then marginal children getting education in response to a subsidy will have lower ability than inframarginal ones. However, if there is heterogeneity across bouseholds in (i) income, (ii) altruism levels, or (iii) in the difference between perceived and actual ability, then marginal children can have higher ability than the inframarginal ones.

Our empirical evidence suggests that a key form of heterogeneity is gender-specific. From a policy perspective, the results suggest that while the scholarship does not necessarily primarily help highability boys from credit-constrained families access secondary education, it does seem to improve access for high initial ability girls from families with lower altruism or more negative beliefs about girls.

\subsection{Labor market impacts of the scholarships}

Proposition 4: While receiving a scholarship weakly increase the recipient's welfare, households with scholarships may have greater, lesser, or equal average earnings in the wage-employment sector, as well as in the full population.

Scholarships may create a selection effect that reduces wage earnings in the private sector by causing low-skill workers to move to wage work from self-employment and high-skill workers to move from the private sector to the public sector. Movements into the public sector increase individual welfare but may reduce earnings since moving to the public sector leads individuals to reduce effort. This is illustrated in Figure 5 Panel B for $0.5<\phi<1$. In this case, while expected utility is always greater in the public sector (as shown in Figure 5 Panel A), wages are always greater in the private sector.

\section{Timing and wage gains versus welfare gains:}

Proposition 5. (i) The treatment effect on earnings in $t=2$ will be less than that in $t=3$. (ii) The treatment effect on earnings in $t=3$ will underestimate the treatment effect on welfare. (iii) Combining (i) and (ii), the treatment effect on earnings in $t=2$ will constitute a lower bound for the treatment effect on welfare in $t=3$.

Although this is not captured by our model, which treats households as risk-neutral over the relevant range of income levels, workers might also prefer public sector jobs over private sector jobs with 
greater mean earnings because public sector jobs offer much more secure income. Recall that females who won scholarships had higher earnings during the pandemic, largely because more held public sector jobs. $^{32}$

\section{Bounds on rate of return to education:}

Students in the treatment group were more likely to still be enrolled in tertiary education in 2019 and 2020 (Table A4). Under the model, we can construct bounds for the impact of senior high school on earnings in this situation. Table A9 presents our estimates for women. The lower bounds are simply the estimates of Table 5. The upper bounds assume, as per the model, that the most talented individuals attend tertiary education. They are therefore computed by removing the highest earners in the control sample until the fraction removed is equivalent to the difference in proportion still in tertiary education between the treatment group and the control group. In this analysis, all those in tertiary school are excluded from the regression.

The 95\% confidence interval for the upper bound of the impact on 2019 earnings runs from 5.4\% to $47.4 \%$. While this is still far from the return to secondary high school as perceived by parents, it encompasses ranges found in other studies in developing settings (e.g. Duflo, 2001).

\section{Effect of scholarships on total economic output:}

Since earnings, net of education costs, are perfectly linked to production in the self-employment and private sectors, any switches between these sectors induced by scholarships will necessarily be followed by an increase in production. However, for switches induced to the public sector, the impact on economic output is ambiguous.

\section{Proposition 6: Scholarships can potentially either increase or decrease economic output, net of education costs.}

It is intuitive that since public sector jobs command rents and are rationed, gains to scholarship winners from obtaining public sector jobs generate losses for others who no longer obtain those positions. This may generate socially excessive investment in education, potentially exacerbated by behavioral biases if households over-estimate the return to education. However other factors can work in the opposite direction. For example, if $A_{g} \gg A_{p}$ and education subsidies increase average skill among the set of people applying to public sector jobs, they could increase total output. On the other

\footnotetext{
32 Excluding women in the public sector, we find a very small and insignificant (50 GHX) impact of the treatment on female earnings in 2020. Thus the women in the public sector seem to account for the bulk, if not all the earnings gain of treatment women during COVID-19.
} 
hand, if $A_{p} \gg A_{g}$ and the subsidy decreases average skill among public sector applicants by making lower-skill workers eligible for public sector jobs, economic production could also increase as highskill workers who can no longer get public-sector positions switch to the private sector.

One last implication of the model is that Mincer-like regressions that do not control for child ability will be subject to bias. This highlights the importance of experimental measurements of the returns to education, as we provide in this paper. In Online Appendix B, we argue that non-educational channels of scholarship effects are likely to be small, and that while exclusion restrictions are probably not fully satisfied, instrumental variable estimates of the effect of education based on random assignment of scholarships are likely to be reasonable approximations of the causal effect of education for the inframarginal students (the compliers in our experiment). We show large differences between OLS and IV estimates of impact on cognitive skills. We then apply recent non-experimental machine learning techniques (Double Machine Learning, or DML) to very flexibly account for a large array of observable variables collected at baseline (Chernozukhov et al, 2018). This remains true in a weighted DML regression that produce estimates for individuals observationally similar to the compliers in our experiment. The fact that the DML estimate stays close to the OLS suggests that observable variables do not fully capture what parents know.

\section{Conclusion}

Using a randomized controlled trial in which a random subset of qualified but financially constrained students in rural Ghana were awarded secondary school scholarships, and detailed outcomes data was collected over 12 years, we identify the partial equilibrium impact of free education on those who obtain education in response to the scholarship. We find that scholarships increase secondary school completion rates by 27 percentage points. Furthermore, we find that secondary education does impart significant learning gains, enable healthier behaviors, and delays fertility and marriage. Those gains tend to be particularly strong for women who are otherwise less likely to access secondary school, perhaps reflecting unequal treatment by gender within the household in some families.

The scholarship led to an increase in the fraction of youth who ever enrolled in tertiary education by 2019 (after 11 years) from 15\% to 20\%. Even though female scholarship winners were more likely to still be enrolled in school at the time of the survey, they were also more likely to be formally employed, and more likely to have public sector jobs and jobs with benefits. Female scholarship winners' earnings were less negatively impacted by the COVID-19 lockdowns. 
While scholarships increased the probability of tertiary education and obtaining a public sector job for women, the overall fraction of secondary school graduates attending tertiary education remains fairly low in this sample. Few of these secondary school graduates will meet their ambition of becoming teachers or entering other occupations requiring tertiary education and commanding high rents. To the extent that government jobs are in fixed supply, there will likely be excessive entry into competing for these jobs since entry creates a negative externality for other applicants. A symptom of this competition is that, in 2013, 67\% of the treatment group (almost all of those who graduated from secondary school) had plans to attend tertiary, but as of 2020 only a third of them (24\%) have been able to carry those plans out. Those who did enroll often spent several years waiting for a place.

We do not find any evidence that the scholarship for free secondary education led to large improvements in earnings overall (except during the COVID-19 crisis, among women). These results may change over time as more of those who have gone to tertiary school graduate and enter the labor market. Employment rates will likely rise in the entire sample as well. This will both increase all wages and give us a larger and more representative sample to estimate any productivity impacts of education. Estimating the long-run returns to free secondary education will require surveying our study sample again in five or ten years, twenty years after they were first identified. This underscores the importance of very long-term longitudinal follow up.

Nevertheless, it appears plausible at this stage that any private labor market gains from education are to a significant extent at the expense of others (if education mainly help graduates get access to a rationed job). Moreover, the slow entry of secondary school graduates in the labor market may reflect in part their long wait for the opportunity to get one of these slots (they don't commit to an alternative occupation as long as they think they still have a chance to get a tertiary slot), which deprives them of some of the benefits of education and may lead to depreciation of human capital (Dinerstein et al., 2020). All told these results, and our model, suggest that if free education was generalized, while we can expect real gains on cognitive skills and health, the impact on overall welfare is unclear given the labor market in Ghana.

One possible response to the overestimation of the chance of obtaining government jobs would be a campaign to provide information to families on the chances of obtaining such jobs. This could also potentially lead families to better plan the types of education investment they make. Of course, it could also have unintended effects, such as discouraging student effort in school. 
A policy of universal free secondary school could be accompanied with a reform of public sector compensation and hiring policies, in order to reduce the distortions caused by the hope of getting access to scarce jobs with large rents. Entry in training programs could be restricted to one or two years after secondary school graduation.

If such a reform is not possible, one potential alternative to universal free education would be more targeted support which maximizes the human capital gains of secondary education while limiting the distortions driven by the competition for scarce jobs. For example, scholarships could be offered to students from disadvantaged background with high scores on the JHS exam. This would make it more likely that they succeed in secondary school and displace less talented richer children. Most obviously, scholarships could be given in priority to girls. Both the model and data suggest that many girls with the potential to succeed will not go to senior high school without scholarships and that scholarships for girls are likely to be particularly impactful on learning outcomes, tertiary education, political awareness, health, and fertility.

\section{References}

Abbott, Brant, Giovanni Gallipoli, Costas Meghir, and Giovanni L. Violante (2019). "Education Policy and Intergenerational Transfers in Equilibrium”. Journal of Political Economy, 127:6, 2569-2624 Ajayi, Kehinde F. (2013). "School Choice and Educational Mobility: Lessons from Secondary School Applications in Ghana". IED Discussion Paper 259.

Ajayi, Kehinde F., Willa H. Friedman, and Adrienne M. Lucas (2020). "When Information is Not Enough: Evidence from a Centralized School Choice System”. NBER Working Paper 27887.

Aryeetey, Ernest, and William Baah-Boateng (2016). “Understanding Ghana's growth success story and job creation challenge.” UNU-WIDER Working paper.

Angrist, Joshua, Eric Bettinger, and Michael Kremer. "Long-term educational consequences of secondary school vouchers: Evidence from administrative records in Colombia." The American Economic Review 96, no. 3 (2006): 847-862.

Banerjee, Abhijit, Esther Duflo and Garima Sharma (2020). "Long-term Effects of the Targeting the Ultra Poor Program”. MIT Working Paper.

Baird, Sarah, Joan Hamory Hicks, Edward Miguel and Michael Kremer (2017). "Worms at Work: Long-run Impacts of Child Health Gains". Quarterly Journal of Economics. 
Barrera-Osorio, Felipe, Leigh L. Linden, and Miguel Urquiola (2007). "The effects of user fee reductions on enrollment: Evidence from a quasi-experiment.” Columbia University.

Barrera-Osorio, Felipe, Marianne Bertrand, Leigh Linden and Francisco Perez (2011). "Improving the Design of Conditional Transfer Programs: Evidence from a Randomized Education Experiment in Colombia." American Economic Journal: Applied Economics. 3(2): 167-95.

Barton, Nicholas, Tessa Bold and Justin Sandefur. 2017. "Measuring the Rents from Public Employment: Regression Discontinuity Evidence from Kenya.” CGD Working Paper 457.

Becker, Gary S. (1991), "An economic analysis of fertility," Demographic and Economic Change in Developed Countries, Gary S. Becker, ed., Princeton: Princeton University Press.

Becker, Gary S., Scott Duke Kominers, Kevin M. Murphy, and Jörg L. Spenkuch (2018). “A Theory of Intergenerational Mobility”. Journal of Political Economy, 126:S1, S7-S25

Benhassine, Najy, Florencia Devoto, Esther Duflo, Pascaline Dupas, and Victor Pouliquen (2015). "Turning a Shove into a Nudge? A 'Labeled Cash Transfer' for Education." American Economic Journal: Economic Policy, 7 (3): 86-125

Benjamini, Yoav, Abba M. Krieger, and Daniel Yekutieli. 2006. “Adaptive Linear Step-Up Procedures That Control the False Discovery Rate.” Biometrika 93(3): 491-507.

Black, Sandra, Paul Devereux and Kjell Silvanes. (2008). "Staying in the classroom and out of the maternity ward? The effect of compulsory schooling laws on teenage births". Economic Journal 118 (539): 1025-1054.

Blattman, Christopher, Nathan Fiala, and Sebastian Martinez. 2020. "The Long-Term Impacts of Grants on Poverty: Nine-Year Evidence from Uganda's Youth Opportunities Program." American Economic Review: Insights, 2 (3): 287-304.

Blaydes, Lisa. (2006). "Who Votes in Authoritarian Elections and Why? Determinants of Voter Turnout in Contemporary Egypt", unpublished.

Blimpo, Moussa P., Ousman Gajigo, and Todd Pugatch. 2019. "Financial Constraints and Girls' Secondary Education: Evidence from School Fee Elimination in The Gambia." The World Bank Economic Review, Vol. 33 (1): 185-208.

Campante, Filipe R. and Davin Chor (2012). "Schooling, Political Participation, and the Economy," The Review of Economics and Statistics, MIT Press, vol. 94(4), pages 841-859, November.

Ministry of Education (MoE) Ghana (2008). "EMIS Basic Educational Data."

Chernozhukov, Victor, Denis Chetverikov, Mert Demirer, Esther Duflo, Christian Hansen, Whitney Newey, James Robins (2018). "Double/Debiased Machine Learning for Treatment and Structural Parameters." The Econometrics Journal 21(1): C1-C68. 
de Mel, Suresh, David J. McKenzie, and Christopher Woodruff (2009). "Measuring microenterprise profits: Must we ask how the sausage is made?" Journal of Development Economics, 88(1): 19-31.

Dinerstein, Michael, Megalokonomou, Rigissa, and Yannelis (2020). "Constantine, Human Capital Depreciation.” University of Chicago, BFI Working Paper No. 2020-146.

Duflo, Esther (2001). "Schooling and Labor Market Consequences of School Construction in Indonesia: Evidence from an Unusual Policy Experiment." American Economic Review 91(4): 795-813.

Duflo, Esther, Pascaline Dupas and Michael Kremer (2015). "Education, HIV, and Early Fertility: Experimental Evidence from Kenya”. American Economic Review, 105(9).

Evans, David; Ngatia, Irene Muthoni. (2020). "School costs, short-run participation, and long-run outcomes: evidence from Kenya". The World Bank Economic Review.

Ferreira, Francisco HG, Deon Filmer, and Norbert Schady (2009). "Own and sibling effects of conditional cash transfer programs: Theory and evidence from Cambodia." World Bank.

Filmer, Deon, and Norbert Schady (2014): “The Medium-Term Effects of Scholarships in a LowIncome Country," Journal of Human Resources, 49(3), pp. 663-694.

Finan, Frederico, Olken and Pande (2015): “The Personnel Economics of the Developing State.” In The Handbook of Field Experiments, Volume II (pp. 467-514).

Friedman, Willa, Edward Miguel, Michael Kremer and Rebecca Thornton (2016). "Education as Liberation?" Economica, 83(329): 1-30.

Gertler, Paul, James Heckman, Rodrigo Pinto, Arianna Zanolini, Christel Vermeersch, Susan Walker, Susan M. Chang, and Sally Grantham-Mcgregor (2014). "Labor market returns to an early childhood stimulation intervention in Jamaica”. Science: 998-1001.

Ghana Statistical Service (2010). "Population \& Housing Census”, accessed 01/12/20:

https://statsghana.gov.gh/gssmain/fileUpload/pressrelease/2010 PHC National Analytical Report.pdf.

Heckman, James J. and Stefano Mosso (2014). “The Economics of Human Development and Social Mobility". Annual Review of Economics, 6:1, 689-733

Hicks, Joan Hamory, Edward Miguel, Michael W. Walker, Michael R. Kremer, and Sarah Baird (2020). “Twenty Year Economic Impacts of Deworming” NBER Working Paper No. w27611.

Jensen, Robert (2010). "The (Perceived) Returns to Education and the Demand for Schooling." The Quarterly Journal of Economics, Volume 125, Issue 2, Pages 515-548.

Kaufmann, K.M. (2014), Understanding the income gradient in college attendance in Mexico: The role of heterogeneity in expected returns. Quantitative Economics, 5: 583-630.

Khandker, Shahidur, Mark Pitt and Nubuhiko Fuwa (2003). "Subsidy to Promote Girls' Education: The Female Stipend Program in Bangladesh.” MPRA Paper 23688 (2003). 
Kremer, Michael, Edward Miguel and Rebecca Thornton (2009) "Incentives to Learn". Review of Economics and Statistics (91)3: 437-456.

Krueger, Alan, and Jitka Maleckova (2003). "Education, Poverty, Political Violence, and Terrorism: Is There a Causal Connection?” Journal of Economic Perspectives, vol. 17, Fall 2003, no. 4, pp.119-144

Lajaaj, Rachid, Andrew Moya and Fabio Sanchez (2018). "Equality of Opportunity and Human Capital Accumulation: Motivational Effect of a Nationwide Scholarship in Colombia”. CEDE Doc 26.

Lam, David, Cally Ardington, and Murray Leibbrandt (2011). "Schooling as a lottery: Racial differences in school advancement in urban South Africa." Journal of Development Economics, 95(2).

LaLonde, Robert J. (1986). "Evaluating the Econometric Evaluations of Training Programs with Experimental Data”. The American Economic Review, 76(4): 604-620.

Lang, Kevin. (1993). “Ability Bias, Discount Rate Bias, and the Return to Education.” Manuscript. Boston: Boston University, Department of Economics.

Murphy, Kevin M., Andrei Shleifer, and Robert W. Vishny (1991). "The allocation of talent: Implications for growth." The quarterly journal of economics 106.2 503-530.

Nguyen, T. (2008). "Information, role models and perceived returns to education: Experimental evidence from Madagascar." Unpublished manuscript.

North, Douglass (1990). Institutions, Institutional Change and Economic Performance. Cambridge.

Ozier, Owen (2018). "The Impact of Secondary Schooling in Kenya: A Regression Discontinuity Analysis," Journal of Human Resources 53 (1): 157-188.

Pritchett, Lant (2001). Where has all the education gone? World Bank Economic Review, 15(3): 367-91.

Pritchett, Lant (2018). The Politics of Learning: Directions for Future Research. RISE working paper.

Rosenzweig, Mark, and T. Paul Schultz (1989). "Schooling, information and nonmarket productivity: contraceptive use and its effectiveness." International Economic Review 30:457-477.

Rosenzweig, Mark, and Christopher Udry (2020). "External Validity in a Stochastic World: Evidence from Low-Income Countries.” The Review of Economic Studies, 87:343-381.

Sondheimer, R. M. and Green, D. P. (2010), Using Experiments to Estimate the Effects of Education on Voter Turnout. American Journal of Political Science, 54: 174-189.

United Nations Girls Initiative (2010). "UNGEI at 10: A Journey to Gender Equality in Education."

Warner, A., A. Malhotra, and A. McGonagle (2012). "Girls education empowerment and transitions to adulthood: The case for a shared agenda." International Center for Research on Women

Yamauchi, Futoshi (2004). “Are experience and schooling complementary? Evidence from migrants' assimilation in the Bangkok labor market”, Journal of Development Economics, 74: 489-513 
Figure 1: Type of work, by education level: Baseline Expectations vs. Realizations

Panel A:

2008 baseline beliefs about likely type of work at age 25 , by hypothetical education

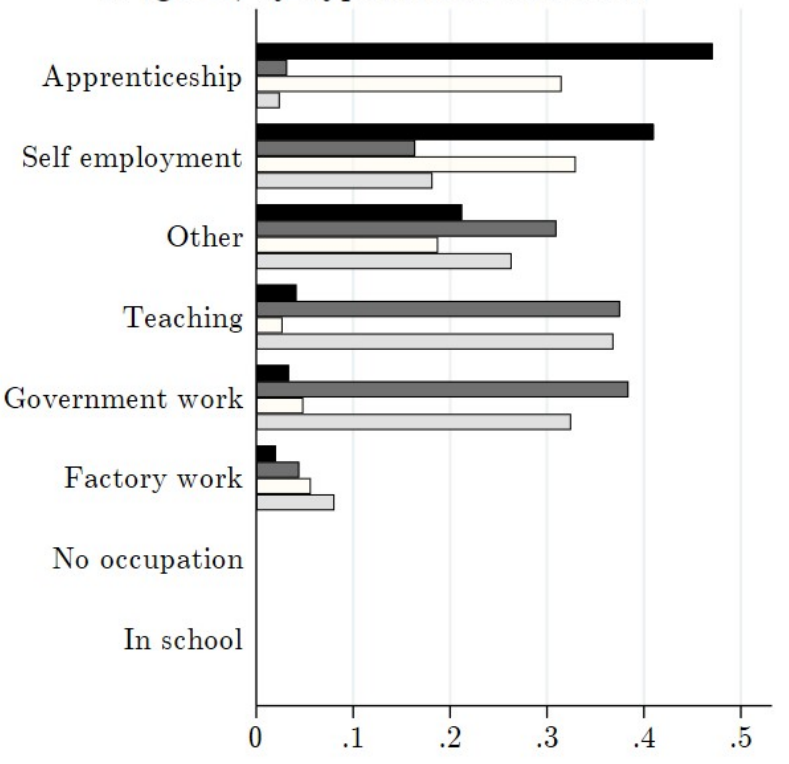

Panel B:

2017 realized career outcomes at age 26 , by realized education level

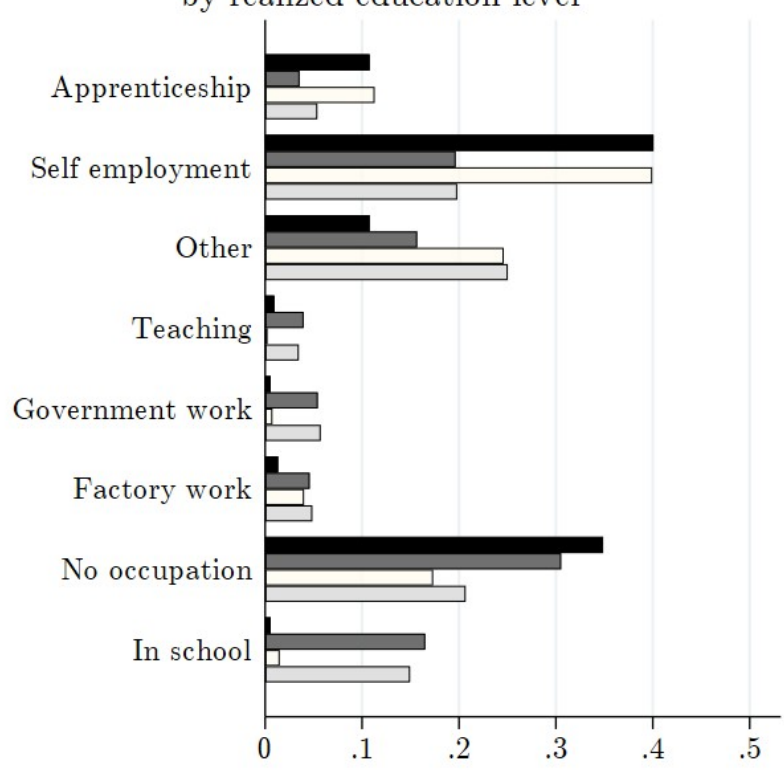

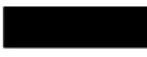

Females with no SHS education

Males with no SHS education
Females with completed SHS education

Males with completed SHS education

Notes: Data from 2008 in-person baseline survey of participants (Panel A) and 2017 phone survey (Panel B). SHS stands for Senior High School. In Panel A, respondents (aged 17 on average at the time) were asked in 2008: "If you never go to SHS or continue any other higher education in the future, what types of work do you think you would do when you are 25 years old?" and "Imagine that you complete Senior High School in the future, what types of work do you think you would do when you are 25 years old?" In Panel B, data from the 2017 phone survey on the realized career outcomes of students who did and did not complete SHS is shown. We plot answers separately by respondent gender, pooling treatment and control groups. 
Figure 2: Impact of Scholarship on SHS Enrollment over time

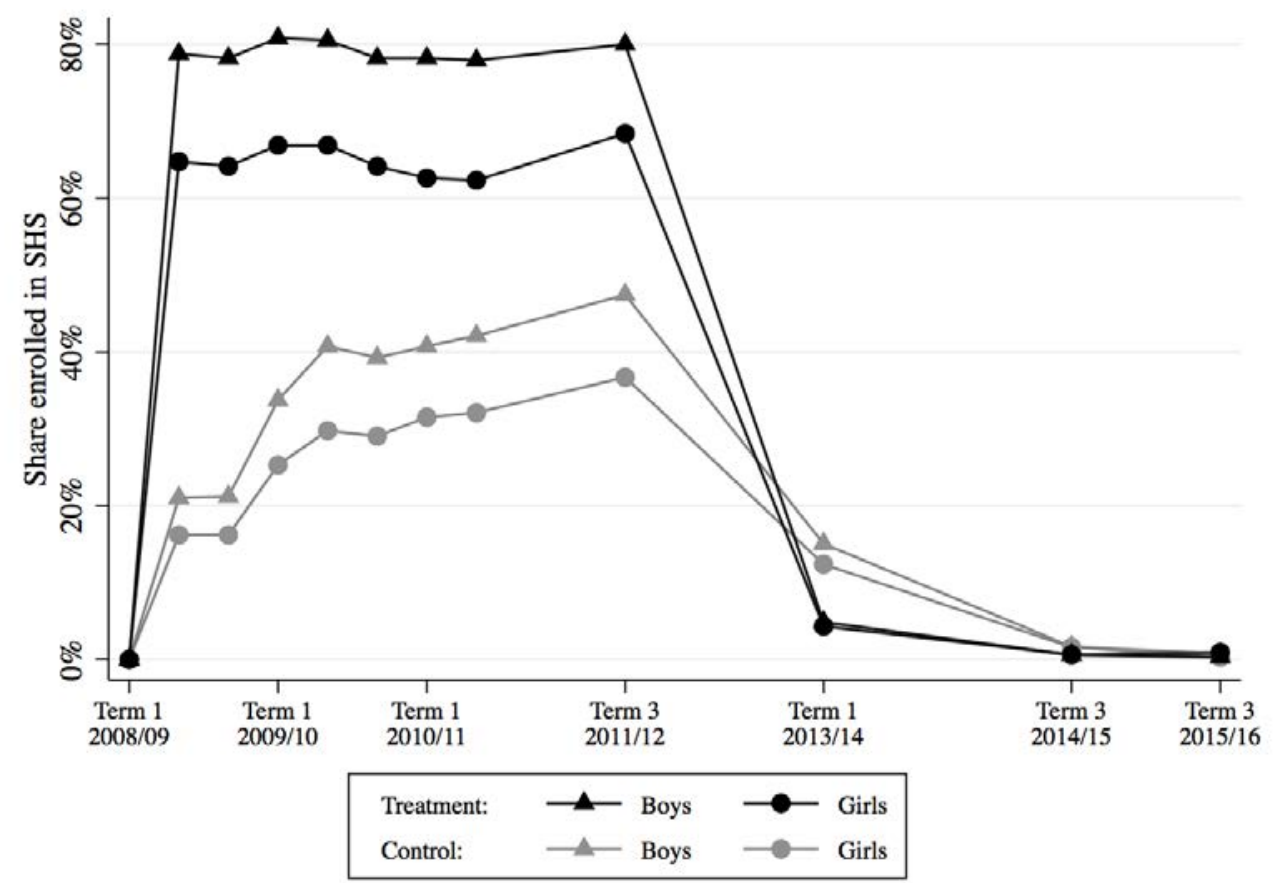

Notes: Data from yearly phone surveys. The scholarships were awarded at the beginning of Term 2 of the 2008/2009 academic year. We split the sample by gender.

Figure 3: Impact of Scholarship on Educational attainment, by entrance exam quartile
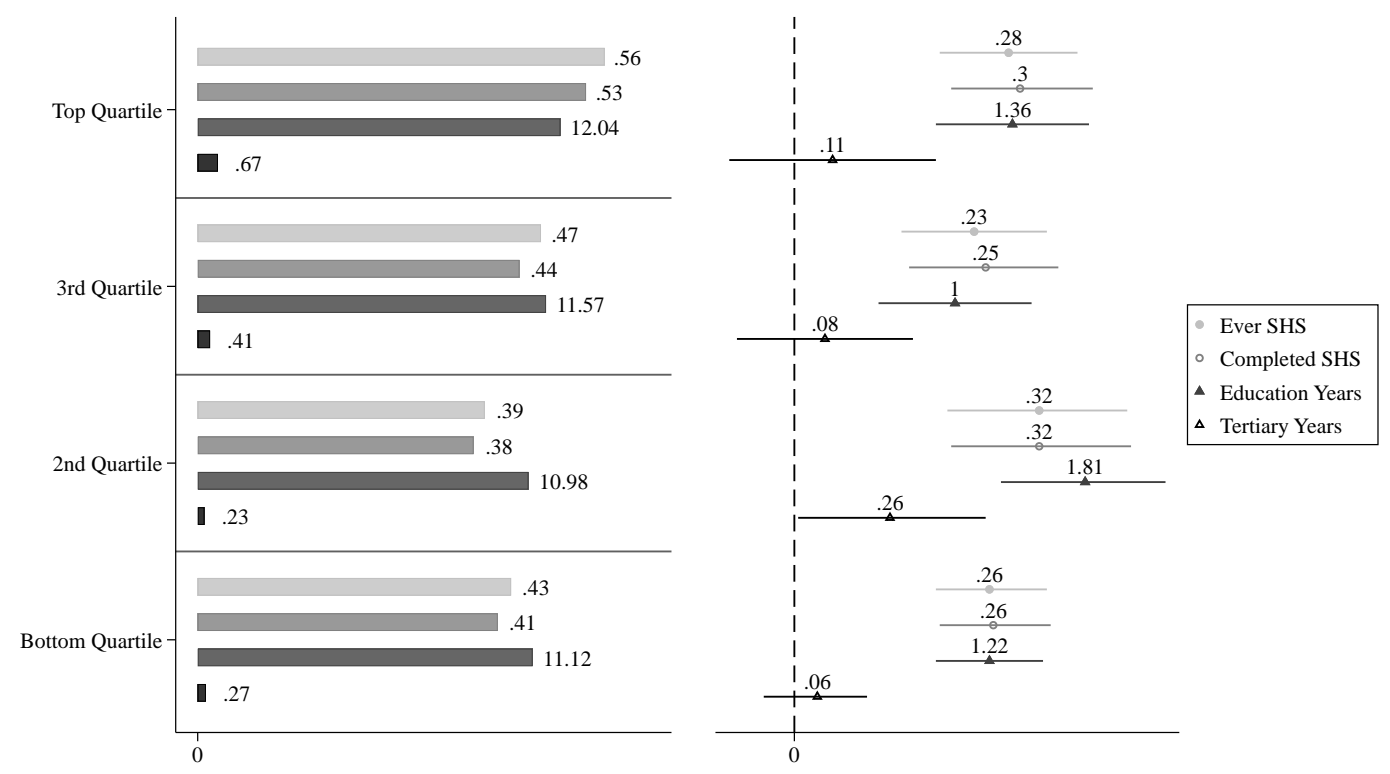

Notes: Educational attainment data from 2019 phone survey. Left half of graph shows means in comparison group; right half shows estimated treatment effects and $95 \%$ confidence intervals. See text for details. 
Figure 4: Impact of Scholarship on Childbearing Onset, by survey year
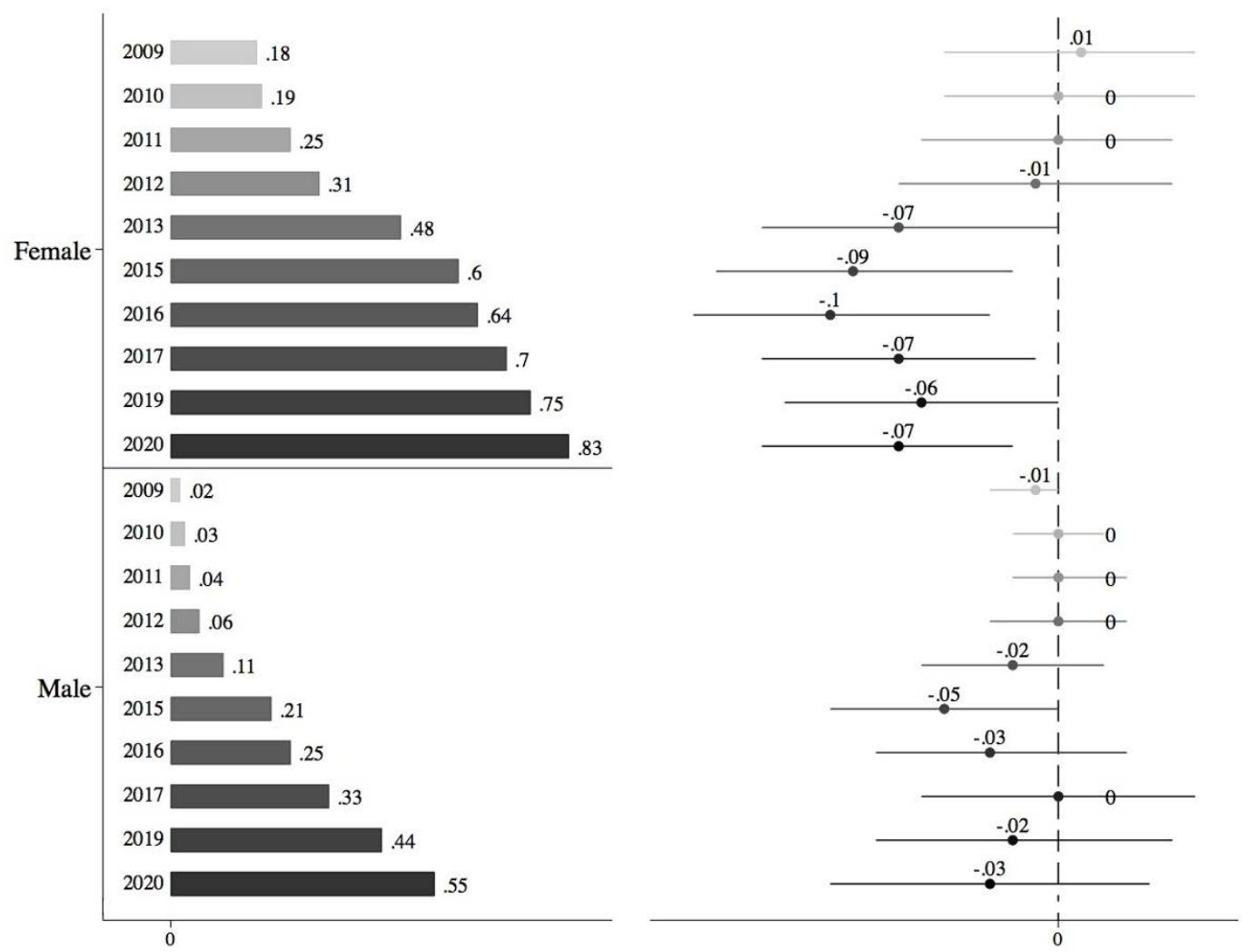

Notes: Data from 2013 in-person follow-up and 2009, 2010, 2011, 2012, 2015, 2016, 2017, 2019, and 2020 phone surveys. The outcome shown is "Ever pregnant", by survey year. "Ever pregnant" means respondent or respondent's partner has ever been pregnant at the time of the survey. Left half of graph shows means in comparison group; right half shows estimated treatment effects and $95 \%$ confidence intervals. 
Figure 5: Model: Expected Utility and Expected Earnings in each Labor Sector

\section{Panel A. Expected Utility}

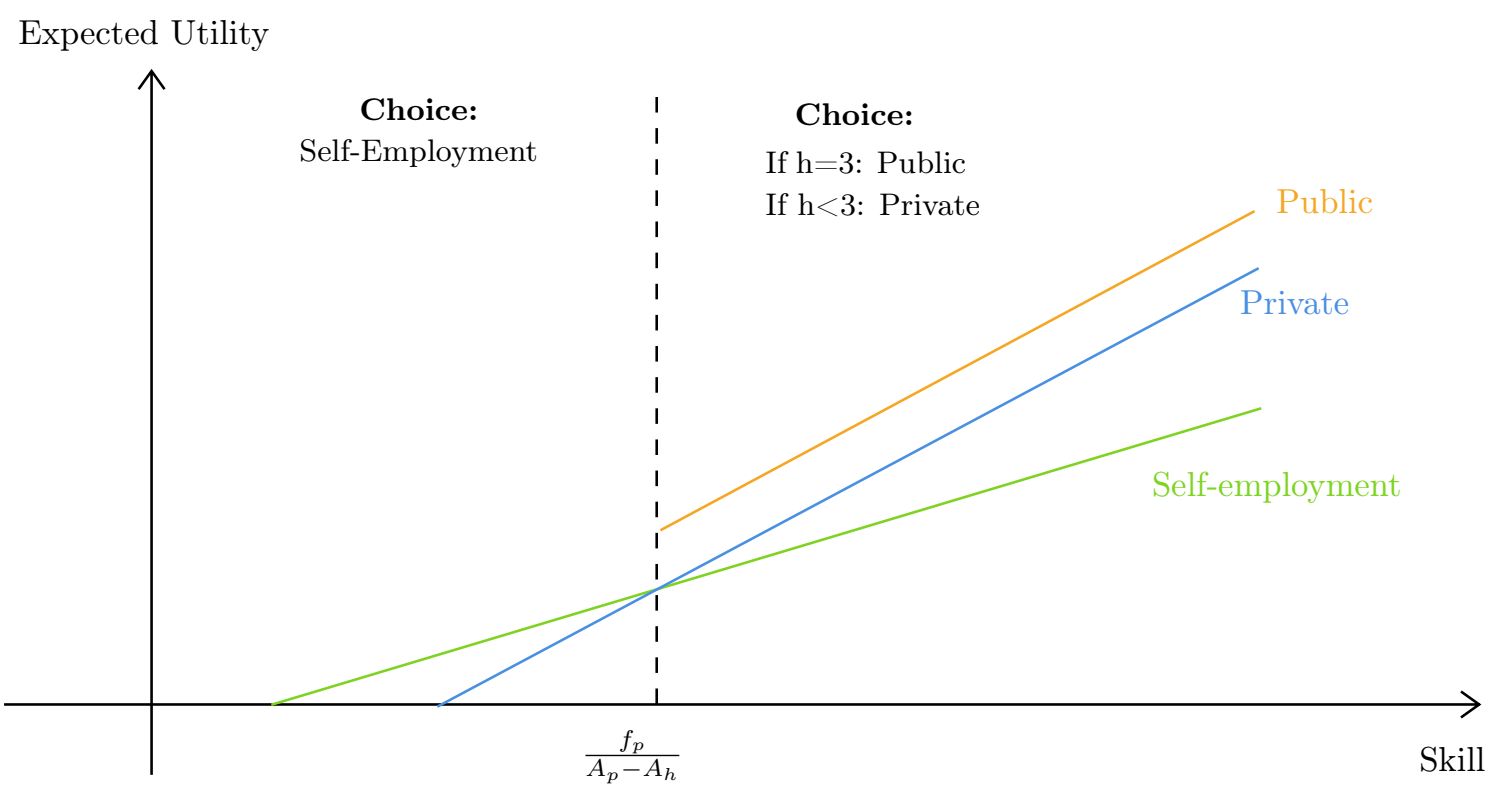

Panel B. Expected Income, assuming $0.5 \leq \phi \leq 1$

Expected Income

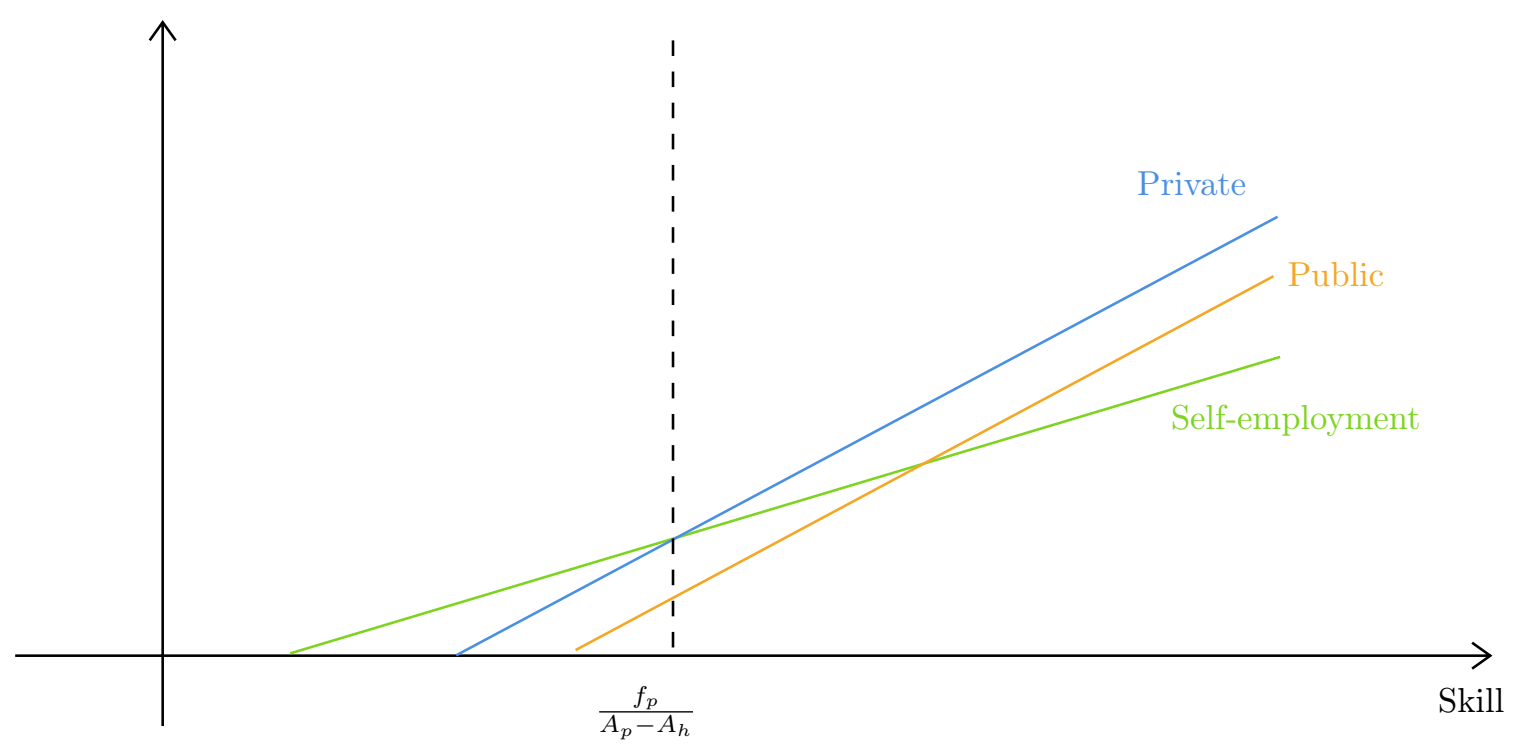


Table 1: Baseline Sample Characteristics and Balance

\begin{tabular}{|c|c|c|c|c|c|c|c|}
\hline & $\begin{array}{c}\text { Age } \\
\text { in } 2008\end{array}$ & $\begin{array}{c}\text { BECE } \\
\text { exam } \\
\text { performance }\end{array}$ & $\begin{array}{c}\text { No male } \\
\text { head } \\
\text { in the } \\
\text { household }\end{array}$ & $\begin{array}{c}\text { Number } \\
\text { of HH } \\
\text { members }\end{array}$ & $\begin{array}{c}(5) \\
\text { Highest } \\
\text { education of } \\
\text { HH head: } \\
\text { primary } \\
\text { or less }\end{array}$ & $\begin{array}{c}(6) \\
\text { Highest } \\
\text { education of } \\
\text { HH head: } \\
\text { SHS } \\
\text { or more }\end{array}$ & $\begin{array}{c}(7) \\
\text { Perceivec } \\
\text { returns } \\
\text { to SHS } \\
(\%) \\
\end{array}$ \\
\hline \multicolumn{8}{|l|}{ Panel A: All } \\
\hline Treatment & $\begin{array}{l}-0.064 \\
(0.073)\end{array}$ & $\begin{array}{c}0.002 \\
(0.004)\end{array}$ & $\begin{array}{c}0.009 \\
(0.023)\end{array}$ & $\begin{array}{l}-0.099 \\
(0.108)\end{array}$ & $\begin{array}{c}0.011 \\
(0.023)\end{array}$ & $\begin{array}{l}-0.001 \\
(0.018)\end{array}$ & $\begin{array}{c}14.639 \\
(28.106)\end{array}$ \\
\hline $\mathrm{P}$-value & 0.376 & 0.585 & 0.706 & 0.361 & 0.625 & 0.945 & 0.603 \\
\hline Comparison mean & 17.369 & 0.623 & 0.425 & 5.659 & 0.483 & 0.171 & 276.102 \\
\hline $\mathrm{N}$ & 2060 & 1924 & 2053 & 2054 & 2049 & 2049 & 1782 \\
\hline \multicolumn{8}{|l|}{ Panel B: Female } \\
\hline Treatment & $\begin{array}{l}-0.050 \\
(0.100)\end{array}$ & $\begin{array}{l}-0.001 \\
(0.005)\end{array}$ & $\begin{array}{l}-0.030 \\
(0.033)\end{array}$ & $\begin{array}{l}-0.144 \\
(0.145)\end{array}$ & $\begin{array}{c}0.024 \\
(0.033)\end{array}$ & $\begin{array}{l}-0.003 \\
(0.025)\end{array}$ & $\begin{array}{c}33.392 \\
(39.913)\end{array}$ \\
\hline $\mathrm{P}$-value & 0.620 & 0.833 & 0.370 & 0.323 & 0.463 & 0.909 & 0.403 \\
\hline Comparison mean & 17.314 & 0.618 & 0.455 & 5.617 & 0.478 & 0.172 & 272.429 \\
\hline $\mathrm{N}$ & 1033 & 961 & 1031 & 1032 & 1030 & 1030 & 874 \\
\hline \multicolumn{8}{|l|}{ Panel C: Male } \\
\hline Treatment & $\begin{array}{l}-0.085 \\
(0.106)\end{array}$ & $\begin{array}{c}0.005 \\
(0.005)\end{array}$ & $\begin{array}{c}0.047 \\
(0.033)\end{array}$ & $\begin{array}{l}-0.054 \\
(0.160)\end{array}$ & $\begin{array}{l}-0.002 \\
(0.033)\end{array}$ & $\begin{array}{c}0.001 \\
(0.025)\end{array}$ & $\begin{array}{c}-1.726 \\
(39.730)\end{array}$ \\
\hline $\mathrm{P}$-value & 0.421 & 0.361 & 0.150 & 0.738 & 0.944 & 0.971 & 0.965 \\
\hline Comparison mean & 17.426 & 0.628 & 0.395 & 5.703 & 0.487 & 0.170 & 279.719 \\
\hline $\mathrm{N}$ & 1027 & 963 & 1022 & 1022 & 1019 & 1019 & 908 \\
\hline
\end{tabular}

Notes: Data from baseline survey (2008). We document pre-intervention characteristics for the comparison group ("comparison mean") and differences between treatment and comparison ("Treatment" coefficient). Panel A shows the full sample, Panel B of females, Panel C of males. The estimated difference between the comparison and treatment groups are in each panel's first row; standard errors are in each panel's second row in parentheses; p-values from the test that the respective treatment-comparison difference is non-zero are reported in the third row; control group means are in each panel's fourth row; sample size for the estimation is in each panel's fifth row. Controls include region dummies. 
Table 2: Education Outcomes

\begin{tabular}{|c|c|c|c|c|c|c|c|c|}
\hline & $\begin{array}{c}(1) \\
\text { Total } \\
\text { years of } \\
\text { education } \\
\text { to date } \\
(2019)\end{array}$ & $\begin{array}{c}(2) \\
\text { Total } \\
\text { years of } \\
\text { SHS } \\
\text { to date } \\
(2019)\end{array}$ & $\begin{array}{c}\text { Completed } \\
\text { SHS } \\
(2019)\end{array}$ & $\begin{array}{c}\text { Completed } \\
\text { TVI } \\
(2019)\end{array}$ & $\begin{array}{c}\text { Completed } \\
\text { tertiary } \\
(2019)\end{array}$ & $\begin{array}{c}(6) \\
\text { Ever } \\
\text { enrolled } \\
\text { in tertiary } \\
\text { program } \\
(2019) \\
\end{array}$ & $\begin{array}{c}(7) \\
\text { Currently } \\
\text { enrolled } \\
\text { in tertiary } \\
\text { program } \\
(2019) \\
\end{array}$ & $\begin{array}{c}(8) \\
\text { Ever } \\
\text { enrolled } \\
\text { in tertiary } \\
\text { program } \\
(2020) \\
\end{array}$ \\
\hline \multicolumn{9}{|l|}{ Panel A: All } \\
\hline Treatment & $\begin{array}{c}1.241 \\
(0.104)\end{array}$ & $\begin{array}{c}1.251 \\
(0.079)\end{array}$ & $\begin{array}{c}0.272 \\
(0.022)\end{array}$ & $\begin{array}{l}-0.020 \\
(0.006)\end{array}$ & $\begin{array}{c}0.035 \\
(0.015)\end{array}$ & $\begin{array}{c}0.044 \\
(0.018)\end{array}$ & $\begin{array}{c}0.010 \\
(0.011)\end{array}$ & $\begin{array}{c}0.047 \\
(0.020)\end{array}$ \\
\hline $\mathrm{P}$-value & 0.000 & 0.000 & 0.000 & 0.001 & 0.019 & 0.016 & 0.346 & 0.019 \\
\hline Comparison mean & 11.387 & 1.842 & 0.436 & 0.029 & 0.087 & 0.154 & 0.049 & 0.179 \\
\hline $\mathrm{N}$ & 1924 & 1925 & 1952 & 1952 & 1952 & 1951 & 1951 & 1740 \\
\hline \multicolumn{9}{|l|}{ Panel B: Female } \\
\hline Treatment & $\begin{array}{c}1.313 \\
(0.155)\end{array}$ & $\begin{array}{c}1.208 \\
(0.119)\end{array}$ & $\begin{array}{c}0.258 \\
(0.032)\end{array}$ & $\begin{array}{l}-0.005 \\
(0.008)\end{array}$ & $\begin{array}{c}0.040 \\
(0.020)\end{array}$ & $\begin{array}{c}0.077 \\
(0.025)\end{array}$ & $\begin{array}{c}0.029 \\
(0.015)\end{array}$ & $\begin{array}{c}0.088 \\
(0.028)\end{array}$ \\
\hline P-value & 0.000 & 0.000 & 0.000 & 0.573 & 0.048 & 0.002 & 0.059 & 0.002 \\
\hline Comparison mean & 11.030 & 1.627 & 0.389 & 0.017 & 0.078 & 0.126 & 0.035 & 0.146 \\
\hline $\mathrm{N}$ & 968 & 968 & 986 & 986 & 986 & 986 & 986 & 856 \\
\hline \multicolumn{9}{|l|}{ Panel C: Male } \\
\hline Treatment & $\begin{array}{c}1.141 \\
(0.138)\end{array}$ & $\begin{array}{c}1.273 \\
(0.104)\end{array}$ & $\begin{array}{c}0.281 \\
(0.031)\end{array}$ & $\begin{array}{l}-0.035 \\
(0.009)\end{array}$ & $\begin{array}{c}0.030 \\
(0.022)\end{array}$ & $\begin{array}{c}0.010 \\
(0.026)\end{array}$ & $\begin{array}{l}-0.009 \\
(0.016)\end{array}$ & $\begin{array}{c}0.007 \\
(0.029)\end{array}$ \\
\hline P-value & 0.000 & 0.000 & 0.000 & 0.000 & 0.162 & 0.709 & 0.588 & 0.804 \\
\hline Comparison mean & 11.758 & 2.065 & 0.485 & 0.041 & 0.096 & 0.184 & 0.065 & 0.210 \\
\hline $\mathrm{N}$ & 956 & 957 & 966 & 966 & 966 & 965 & 965 & 884 \\
\hline$P$-val male $=$ fem & 0.467 & 0.580 & 0.529 & 0.009 & 0.734 & 0.069 & 0.098 & 0.045 \\
\hline
\end{tabular}

Notes: Year of survey in parentheses. Panel A shows results for the full sample, Panel B for females, Panel C for males. The last row shows the p-values for tests that the effects are identical between males and females. The estimated treatment effects are in each panel's first row; standard errors are in each panel's second row in parentheses; p-values from the test that a respective treatment effect is non-zero are reported in the third row; control group means are in each panel's fourth row; sample size for the estimation is in each panel's fifth row. Controls include baseline score on Ghana's exam for admission to secondary and vocational schools, an indicator for whether the student took the exam, and region dummies. 
Table 3: Skills and Technology Adoption

\begin{tabular}{|c|c|c|c|c|c|c|c|c|c|}
\hline & $\begin{array}{c}\text { Total } \\
\text { years of } \\
\text { education } \\
(2013)\end{array}$ & $\begin{array}{c}\text { Total } \\
\text { cognitive } \\
\text { score } \\
(2013)\end{array}$ & $\begin{array}{c}\text { Political } \\
\text { knowledge } \\
\text { score } \\
(2013)\end{array}$ & $\begin{array}{c}(4) \\
\text { Media } \\
\text { engagement } \\
\text { (radio, newspaper, } \\
\text { TV, internet) } \\
(2013)\end{array}$ & $\begin{array}{c}(5) \\
\text { Knows } \\
\text { how } \\
\text { to use } \\
\text { internet } \\
(2013)\end{array}$ & $\begin{array}{c}(6) \\
\text { Has a } \\
\text { bank } \\
\text { account } \\
(2013)\end{array}$ & $\begin{array}{c}(7) \\
\text { ICT } / \text { Social } \\
\text { media } \\
\text { adoption } \\
\text { index } \\
(2016)\end{array}$ & $\begin{array}{c}(8) \\
\text { Uses } \\
\text { fertilizer } \\
\quad \text { (if in } \\
\text { farming) } \\
(2017)\end{array}$ & $\begin{array}{c}(9) \\
\text { Used } \\
\text { internet } \\
\text { in the past } \\
\text { month } \\
(2019)\end{array}$ \\
\hline \multicolumn{10}{|l|}{ Panel A: All } \\
\hline Treatment & $\begin{array}{c}1.191 \\
(0.077)\end{array}$ & $\begin{array}{c}0.157 \\
(0.046)\end{array}$ & $\begin{array}{c}0.095 \\
(0.046)\end{array}$ & $\begin{array}{c}0.060 \\
(0.025)\end{array}$ & $\begin{array}{c}0.086 \\
(0.047)\end{array}$ & $\begin{array}{c}0.058 \\
(0.023)\end{array}$ & $\begin{array}{c}0.062 \\
(0.037)\end{array}$ & $\begin{array}{c}-0.024 \\
(0.037)\end{array}$ & $\begin{array}{c}0.059 \\
(0.024)\end{array}$ \\
\hline $\mathrm{P}$-value & 0.000 & 0.001 & 0.040 & 0.018 & 0.069 & 0.011 & 0.095 & 0.527 & 0.013 \\
\hline Comparison mean & 10.787 & -0.000 & 0.000 & -0.020 & 0.000 & 0.314 & -0.133 & 0.471 & 0.493 \\
\hline $\mathrm{N}$ & 2064 & 1983 & 1981 & 1981 & 1983 & 1984 & 1995 & 769 & 1950 \\
\hline \multicolumn{10}{|l|}{ Panel B: Female } \\
\hline Treatment & $\begin{array}{c}1.186 \\
(0.114)\end{array}$ & $\begin{array}{c}0.194 \\
(0.069)\end{array}$ & $\begin{array}{c}0.075 \\
(0.058)\end{array}$ & $\begin{array}{c}0.074 \\
(0.032)\end{array}$ & $\begin{array}{c}0.050 \\
(0.058)\end{array}$ & $\begin{array}{c}0.098 \\
(0.031)\end{array}$ & $\begin{array}{c}0.090 \\
(0.054)\end{array}$ & $\begin{array}{c}0.020 \\
(0.057)\end{array}$ & $\begin{array}{c}0.076 \\
(0.033)\end{array}$ \\
\hline P-value & 0.000 & 0.005 & 0.192 & 0.023 & 0.386 & 0.001 & 0.095 & 0.720 & 0.023 \\
\hline Comparison mean & 10.575 & -0.175 & -0.381 & -0.165 & -0.333 & 0.236 & -0.416 & 0.410 & 0.402 \\
\hline $\mathrm{N}$ & 1036 & 1002 & 1001 & 1001 & 1001 & 1002 & 1007 & 337 & 985 \\
\hline \multicolumn{10}{|l|}{ Panel C: Male } \\
\hline Treatment & $\begin{array}{c}1.183 \\
(0.101)\end{array}$ & $\begin{array}{c}0.113 \\
(0.059)\end{array}$ & $\begin{array}{c}0.094 \\
(0.061)\end{array}$ & $\begin{array}{c}0.035 \\
(0.037)\end{array}$ & $\begin{array}{c}0.101 \\
(0.067)\end{array}$ & $\begin{array}{c}0.016 \\
(0.033)\end{array}$ & $\begin{array}{c}0.016 \\
(0.045)\end{array}$ & $\begin{array}{c}-0.059 \\
(0.050)\end{array}$ & $\begin{array}{c}0.033 \\
(0.033)\end{array}$ \\
\hline P-value & 0.000 & 0.054 & 0.126 & 0.347 & 0.133 & 0.630 & 0.724 & 0.238 & 0.310 \\
\hline Comparison mean & 11.006 & 0.183 & 0.397 & 0.131 & 0.346 & 0.396 & 0.162 & 0.522 & 0.590 \\
\hline $\mathrm{N}$ & 1028 & 981 & 980 & 980 & 982 & 982 & 988 & 432 & 965 \\
\hline$P$-val male $=$ fem & 0.963 & 0.371 & 0.807 & 0.396 & 0.577 & 0.066 & 0.302 & 0.290 & 0.430 \\
\hline
\end{tabular}

Notes: See Table 2 notes. Total cognitive score refers to standardized score on combined reading and math test, administered at the 2013 survey. Political knowledge score is a standardized index of national and international political knowledge scores. The national political knowledge score is comprised of the following: could name President of Ghana, Vice President of Ghana, knew political party in power before 2012 election in Ghana, could name presidential running mate for the NPP, knew how many years someone could be legally elected President in Ghana, knew number of candidates that participated in presidential elections, knew number of new constituencies created in 2012 general elections. The international political knowledge index is comprised of the following: knows name of current U.S. President, knows name of UN Secretary General, knows countries that border Ghana, knows country with largest population in Africa, knows name of Venezuelan President who died in 2013, knows which country Muamar Qaddafi led, knows name of leader from Cote D'Ivoire that ICC tried. The media engagement index is comprised of: has a preferred newspaper, number of days in the last 7 that did each of the following: read newspaper, listened to radio, watched TV, used internet. ICT adoption index (2016) is comprised of the following variables: has Facebook account, knows how to use internet, and has internet on phone. 
Table 4: Civic and Media Engagement Outcomes

\begin{tabular}{|c|c|c|c|c|c|}
\hline & $\begin{array}{c}(1) \\
\text { Has voting } \\
\text { card } \\
(2013)\end{array}$ & $\begin{array}{c}(2) \\
\text { Voted in } \\
2012 \text { national } \\
\text { election (2013) }\end{array}$ & $\begin{array}{c}(3) \\
\text { Voted in last } \\
\text { District Assembly } \\
\text { election (2013) }\end{array}$ & $\begin{array}{c}(4) \\
\text { Voted in } \\
2016 \text { national } \\
\text { election }(2017)\end{array}$ & $\begin{array}{c}(5) \\
\text { Voted in last } \\
\text { District Assembly } \\
\text { election }(2017)\end{array}$ \\
\hline \multicolumn{6}{|l|}{ Panel A: All } \\
\hline Treatment & $\begin{array}{c}0.015 \\
(0.008)\end{array}$ & $\begin{array}{l}-0.025 \\
(0.018)\end{array}$ & $\begin{array}{l}-0.006 \\
(0.021)\end{array}$ & $\begin{array}{l}-0.016 \\
(0.021)\end{array}$ & $\begin{array}{l}-0.019 \\
(0.024)\end{array}$ \\
\hline P-value & 0.062 & 0.178 & 0.783 & 0.430 & 0.428 \\
\hline Comparison mean & 0.961 & 0.837 & 0.281 & 0.759 & 0.463 \\
\hline $\mathrm{N}$ & 1980 & 1977 & 1979 & 1965 & 1965 \\
\hline \multicolumn{6}{|l|}{ Panel B: Female } \\
\hline Treatment & $\begin{array}{c}0.016 \\
(0.011)\end{array}$ & $\begin{array}{l}-0.019 \\
(0.027)\end{array}$ & $\begin{array}{l}-0.032 \\
(0.029)\end{array}$ & $\begin{array}{l}-0.023 \\
(0.030)\end{array}$ & $\begin{array}{l}-0.054 \\
(0.033)\end{array}$ \\
\hline P-value & 0.128 & 0.476 & 0.272 & 0.446 & 0.105 \\
\hline Comparison mean & 0.962 & 0.817 & 0.269 & 0.739 & 0.461 \\
\hline $\mathrm{N}$ & 1000 & 999 & 999 & 995 & 995 \\
\hline \multicolumn{6}{|l|}{ Panel C: Male } \\
\hline Treatment & $\begin{array}{c}0.013 \\
(0.012)\end{array}$ & $\begin{array}{l}-0.032 \\
(0.025)\end{array}$ & $\begin{array}{c}0.020 \\
(0.031)\end{array}$ & $\begin{array}{l}-0.014 \\
(0.028)\end{array}$ & $\begin{array}{c}0.016 \\
(0.034)\end{array}$ \\
\hline $\mathrm{P}$-value & 0.268 & 0.199 & 0.505 & 0.631 & 0.626 \\
\hline Comparison mean & 0.960 & 0.858 & 0.294 & 0.780 & 0.465 \\
\hline $\mathrm{N}$ & 980 & 978 & 980 & 970 & 970 \\
\hline $\mathrm{P}$-val male $=\mathrm{fem}$ & 0.833 & 0.734 & 0.247 & 0.786 & 0.129 \\
\hline
\end{tabular}

Notes: See Table 2 notes. 
Table 5: Fertility and Partners

\begin{tabular}{|c|c|c|c|c|c|c|c|c|}
\hline & $\begin{array}{c}(1) \\
\text { Ever } \\
\text { pregnant/ } \\
\text { had a } \\
\text { pregnant } \\
\text { partner } \\
(2013)\end{array}$ & $\begin{array}{c}(2) \\
\text { Had } \\
\text { unwanted } \\
\text { first } \\
\text { pregnancy } \\
\text { (full sample) } \\
(2013)\end{array}$ & $\begin{array}{c}\text { Number } \\
\text { of } \\
\text { children } \\
\text { ever had } \\
(2019)\end{array}$ & $\begin{array}{c}\text { Ever } \\
\text { lived } \\
\text { with } \\
\text { partner } \\
(2016)\end{array}$ & $\begin{array}{c}\text { Currently } \\
\text { married } \\
\text { or } \\
\text { cohabitating } \\
\text { (2019) }\end{array}$ & $\begin{array}{c}\text { (6) } \\
\text { Still } \\
\text { living } \\
\text { with } \\
\text { parents } \\
(2019)\end{array}$ & $\begin{array}{c}(7) \\
\text { Most } \\
\text { recent } \\
\text { partner has } \\
\text { tertiary } \\
\text { education } \\
(2019)\end{array}$ & $\begin{array}{c}(8) \\
\text { Any } \\
\text { child } \\
\text { deceased } \\
\text { before } \\
\text { age } 3 \\
(2019)\end{array}$ \\
\hline \multicolumn{9}{|l|}{ Panel A: All } \\
\hline Treatment & $\begin{array}{l}-0.048 \\
(0.021)\end{array}$ & $\begin{array}{l}-0.044 \\
(0.019)\end{array}$ & $\begin{array}{l}-0.104 \\
(0.053)\end{array}$ & $\begin{array}{l}-0.093 \\
(0.022)\end{array}$ & $\begin{array}{l}-0.058 \\
(0.023)\end{array}$ & $\begin{array}{c}0.039 \\
(0.022)\end{array}$ & $\begin{array}{c}0.019 \\
(0.026)\end{array}$ & $\begin{array}{l}-0.025 \\
(0.021)\end{array}$ \\
\hline P-value & 0.021 & 0.024 & 0.052 & 0.000 & 0.011 & 0.085 & 0.462 & 0.227 \\
\hline Comparison mean & 0.299 & 0.235 & 0.960 & 0.366 & 0.386 & 0.300 & 0.148 & 0.092 \\
\hline $\mathrm{N}$ & 1981 & 1965 & 1951 & 1995 & 1951 & 1952 & 946 & 789 \\
\hline \multicolumn{9}{|l|}{ Panel B: Female } \\
\hline Treatment & $\begin{array}{l}-0.070 \\
(0.033)\end{array}$ & $\begin{array}{l}-0.067 \\
(0.032)\end{array}$ & $\begin{array}{l}-0.152 \\
(0.082)\end{array}$ & $\begin{array}{l}-0.121 \\
(0.033)\end{array}$ & $\begin{array}{l}-0.062 \\
(0.034)\end{array}$ & $\begin{array}{c}0.003 \\
(0.033)\end{array}$ & $\begin{array}{c}0.071 \\
(0.039)\end{array}$ & $\begin{array}{l}-0.036 \\
(0.025)\end{array}$ \\
\hline P-value & 0.037 & 0.038 & 0.065 & 0.000 & 0.067 & 0.933 & 0.071 & 0.143 \\
\hline Comparison mean & 0.479 & 0.390 & 1.332 & 0.498 & 0.475 & 0.355 & 0.195 & 0.099 \\
\hline $\mathrm{N}$ & 1001 & 985 & 986 & 1007 & 986 & 986 & 575 & 556 \\
\hline \multicolumn{9}{|l|}{ Panel C: Male } \\
\hline Treatment & $\begin{array}{c}-0.020 \\
(0.020)\end{array}$ & $\begin{array}{l}-0.012 \\
(0.017)\end{array}$ & $\begin{array}{c}-0.026 \\
(0.060)\end{array}$ & $\begin{array}{c}-0.058 \\
(0.026)\end{array}$ & $\begin{array}{l}-0.047 \\
(0.030)\end{array}$ & $\begin{array}{c}0.078 \\
(0.031)\end{array}$ & $\begin{array}{c}-0.051 \\
(0.022)\end{array}$ & $\begin{array}{c}0.001 \\
(0.036)\end{array}$ \\
\hline P-value & 0.325 & 0.475 & 0.671 & 0.027 & 0.117 & 0.011 & 0.022 & 0.987 \\
\hline Comparison mean & 0.111 & 0.075 & 0.568 & 0.229 & 0.291 & 0.242 & 0.072 & 0.076 \\
\hline $\mathrm{N}$ & 980 & 980 & 965 & 988 & 965 & 966 & 371 & 233 \\
\hline$P$-val male $=$ fem & 0.211 & 0.136 & 0.246 & 0.138 & 0.703 & 0.097 & 0.008 & 0.419 \\
\hline
\end{tabular}

Notes: See Table 2 notes. 
Table 6: Labor Market Outcomes

\begin{tabular}{|c|c|c|c|c|c|c|c|c|}
\hline & (1) & $(2)$ & (3) & (4) & $(5)$ & (6) & $(7)$ & $(8)$ \\
\hline & $\begin{array}{c}\text { Worked for } \\
\text { pay in past } \\
6 \text { months } \\
(2019)\end{array}$ & $\begin{array}{c}\text { Has wage } \\
\text { contract with } \\
\text { employer } \\
(2019)\end{array}$ & $\begin{array}{c}\text { Job } \\
\text { with } \\
\text { benefits } \\
(2019)\end{array}$ & $\begin{array}{c}\text { Public } \\
\text { sector } \\
\text { employee } \\
(2019)\end{array}$ & $\begin{array}{c}\text { Lives } \\
\text { in urban } \\
\text { area } \\
(2019)\end{array}$ & $\begin{array}{c}\text { Self- } \\
\text { employed } \\
(2019)\end{array}$ & $\begin{array}{c}\text { Total } \\
\text { earnings in } \\
\text { past } 6 \\
\text { months } \\
(2019)\end{array}$ & $\begin{array}{c}\text { Could not } \\
\text { cope with } \\
200 \text { GHX } \\
\text { emergency } \\
(2019)\end{array}$ \\
\hline \multicolumn{9}{|l|}{ Panel A: All } \\
\hline \multirow[t]{2}{*}{ Treatment } & 0.011 & 0.039 & 0.030 & 0.019 & -0.015 & -0.029 & 37.123 & -0.027 \\
\hline & $(0.021)$ & $(0.015)$ & $(0.015)$ & $(0.013)$ & $(0.015)$ & $(0.020)$ & $(93.450)$ & $(0.017)$ \\
\hline$P$-value & 0.589 & 0.008 & 0.052 & 0.157 & 0.330 & 0.153 & 0.691 & 0.117 \\
\hline Comparison mean & 0.730 & 0.084 & 0.099 & 0.077 & 0.123 & 0.245 & 1456.217 & 0.161 \\
\hline $\mathrm{N}$ & 1952 & 1951 & 1951 & 1952 & 1921 & 1952 & 1915 & 1951 \\
\hline \multicolumn{9}{|l|}{ Panel B: Female } \\
\hline \multirow[t]{2}{*}{ Treatment } & 0.033 & 0.041 & 0.020 & 0.041 & -0.029 & -0.012 & 35.794 & -0.044 \\
\hline & $(0.033)$ & $(0.019)$ & $(0.019)$ & $(0.019)$ & $(0.021)$ & $(0.031)$ & $(108.464)$ & $(0.024)$ \\
\hline P-value & 0.314 & 0.032 & 0.283 & 0.031 & 0.152 & 0.683 & 0.741 & 0.070 \\
\hline Comparison mean & 0.602 & 0.063 & 0.075 & 0.063 & 0.119 & 0.287 & 951.456 & 0.176 \\
\hline $\mathrm{N}$ & 986 & 986 & 986 & 986 & 973 & 986 & 972 & 986 \\
\hline \multicolumn{9}{|l|}{ Panel C: Male } \\
\hline \multirow[t]{2}{*}{ Treatment } & -0.020 & 0.035 & 0.037 & -0.003 & -0.001 & -0.042 & -12.740 & -0.009 \\
\hline & $(0.024)$ & $(0.023)$ & $(0.024)$ & $(0.019)$ & $(0.023)$ & $(0.026)$ & $(145.790)$ & $(0.024)$ \\
\hline $\mathrm{P}$-value & 0.405 & 0.119 & 0.126 & 0.874 & 0.959 & 0.106 & 0.930 & 0.718 \\
\hline Comparison mean & 0.864 & 0.106 & 0.125 & 0.092 & 0.128 & 0.201 & 1993.862 & 0.146 \\
\hline $\mathrm{N}$ & 966 & 965 & 965 & 966 & 948 & 966 & 943 & 965 \\
\hline $\mathrm{P}$-val male $=$ fem & 0.207 & 0.856 & 0.572 & 0.092 & 0.421 & 0.536 & 0.838 & 0.319 \\
\hline
\end{tabular}

Notes: See Table 2 notes. Total earnings in last 6 months winsorized at the $99 \%$ level. Labor market outcomes for 2017 shown in Table A8, those for 2020 shown in Table 7. 
Table 7: Labor Market Outcomes during COVID Crisis

\begin{tabular}{|c|c|c|c|c|c|c|c|c|c|}
\hline & $\begin{array}{c}(1) \\
\text { Worked } \\
\text { for pay } \\
\text { in past } \\
6 \text { months } \\
(2020) \\
\end{array}$ & $\begin{array}{c}(2) \\
\text { Has wage } \\
\text { contract } \\
\text { with } \\
\text { employer } \\
(2020) \\
\end{array}$ & $\begin{array}{c}(3) \\
\text { Job } \\
\text { with } \\
\text { benefits } \\
(2020) \\
\end{array}$ & $\begin{array}{c}\text { Public } \\
\text { sector } \\
\text { employee } \\
(2020) \\
\end{array}$ & $\begin{array}{c}\text { Lives } \\
\text { in urban } \\
\text { area } \\
(2020)\end{array}$ & $\begin{array}{c}\text { Self- } \\
\text { employed } \\
(2020) \\
\end{array}$ & $\begin{array}{c}(7) \\
\text { Total } \\
\text { earnings } \\
\text { in past } \\
6 \text { months } \\
(2020) \\
\end{array}$ & $\begin{array}{c}\text { Total } \\
\text { earnings } \\
\text { April } \\
(2020)\end{array}$ & $\begin{array}{c}(9) \\
\text { Coeff. of } \\
\text { variation } \\
\text { of monthly } \\
\text { earnings (if }>0) \\
(\mathrm{GHX})(2020)\end{array}$ \\
\hline \multicolumn{10}{|l|}{ Panel A: All } \\
\hline Treatment & $\begin{array}{c}0.045 \\
(0.020)\end{array}$ & $\begin{array}{c}0.047 \\
(0.016)\end{array}$ & $\begin{array}{c}0.005 \\
(0.015)\end{array}$ & $\begin{array}{c}0.015 \\
(0.014)\end{array}$ & $\begin{array}{l}-0.019 \\
(0.016)\end{array}$ & $\begin{array}{l}-0.066 \\
(0.023)\end{array}$ & $\begin{array}{c}62.606 \\
(125.938)\end{array}$ & $\begin{array}{c}30.743 \\
(25.424)\end{array}$ & $\begin{array}{l}-0.776 \\
(3.910)\end{array}$ \\
\hline P-value & 0.027 & 0.003 & 0.732 & 0.303 & 0.238 & 0.004 & 0.619 & 0.227 & 0.843 \\
\hline Comparison mean & 0.760 & 0.081 & 0.102 & 0.082 & 0.124 & 0.342 & 1808.426 & 252.299 & 76.538 \\
\hline $\mathrm{N}$ & 1737 & 1730 & 1730 & 1735 & 1714 & 1733 & 1672 & 1713 & 1251 \\
\hline \multicolumn{10}{|l|}{ Panel B: Female } \\
\hline Treatment & $\begin{array}{c}0.057 \\
(0.034)\end{array}$ & $\begin{array}{c}0.067 \\
(0.021)\end{array}$ & $\begin{array}{c}0.031 \\
(0.019)\end{array}$ & $\begin{array}{c}0.039 \\
(0.020)\end{array}$ & $\begin{array}{l}-0.039 \\
(0.022)\end{array}$ & $\begin{array}{l}-0.068 \\
(0.034)\end{array}$ & $\begin{array}{c}262.979 \\
(149.376)\end{array}$ & $\begin{array}{c}67.620 \\
(24.744)\end{array}$ & $\begin{array}{r}-10.473 \\
(6.201)\end{array}$ \\
\hline $\mathrm{P}$-value & 0.092 & 0.001 & 0.107 & 0.046 & 0.074 & 0.048 & 0.079 & 0.006 & 0.092 \\
\hline Comparison mean & 0.632 & 0.050 & 0.058 & 0.056 & 0.125 & 0.386 & 1008.077 & 115.131 & 89.819 \\
\hline $\mathrm{N}$ & 856 & 853 & 853 & 855 & 846 & 853 & 826 & 843 & 513 \\
\hline \multicolumn{10}{|l|}{ Panel C: Male } \\
\hline Treatment & $\begin{array}{c}0.028 \\
(0.021)\end{array}$ & $\begin{array}{c}0.027 \\
(0.024)\end{array}$ & $\begin{array}{l}-0.022 \\
(0.024)\end{array}$ & $\begin{array}{l}-0.009 \\
(0.021)\end{array}$ & $\begin{array}{c}0.001 \\
(0.024)\end{array}$ & $\begin{array}{l}-0.063 \\
(0.031)\end{array}$ & $\begin{array}{l}-167.123 \\
(191.467)\end{array}$ & $\begin{array}{l}-10.776 \\
(42.674)\end{array}$ & $\begin{array}{c}5.911 \\
(5.024)\end{array}$ \\
\hline $\mathrm{P}$-value & 0.179 & 0.252 & 0.359 & 0.660 & 0.964 & 0.042 & 0.383 & 0.801 & 0.240 \\
\hline Comparison mean & 0.887 & 0.112 & 0.146 & 0.108 & 0.124 & 0.298 & 2607.316 & 388.009 & 67.376 \\
\hline $\mathrm{N}$ & 881 & 877 & 877 & 880 & 868 & 880 & 846 & 870 & 738 \\
\hline $\mathrm{P}$-val male $=$ fem & 0.463 & 0.234 & 0.097 & 0.097 & 0.256 & 0.849 & 0.089 & 0.128 & 0.037 \\
\hline
\end{tabular}

Notes: See Table 2 notes. 2020 survey was administered over the phone (no in-person tracking) between May 19 and September 25 2020 . 
Figure A1: Impact of Scholarship on Cognitive skills by school category and entrance exam quartile
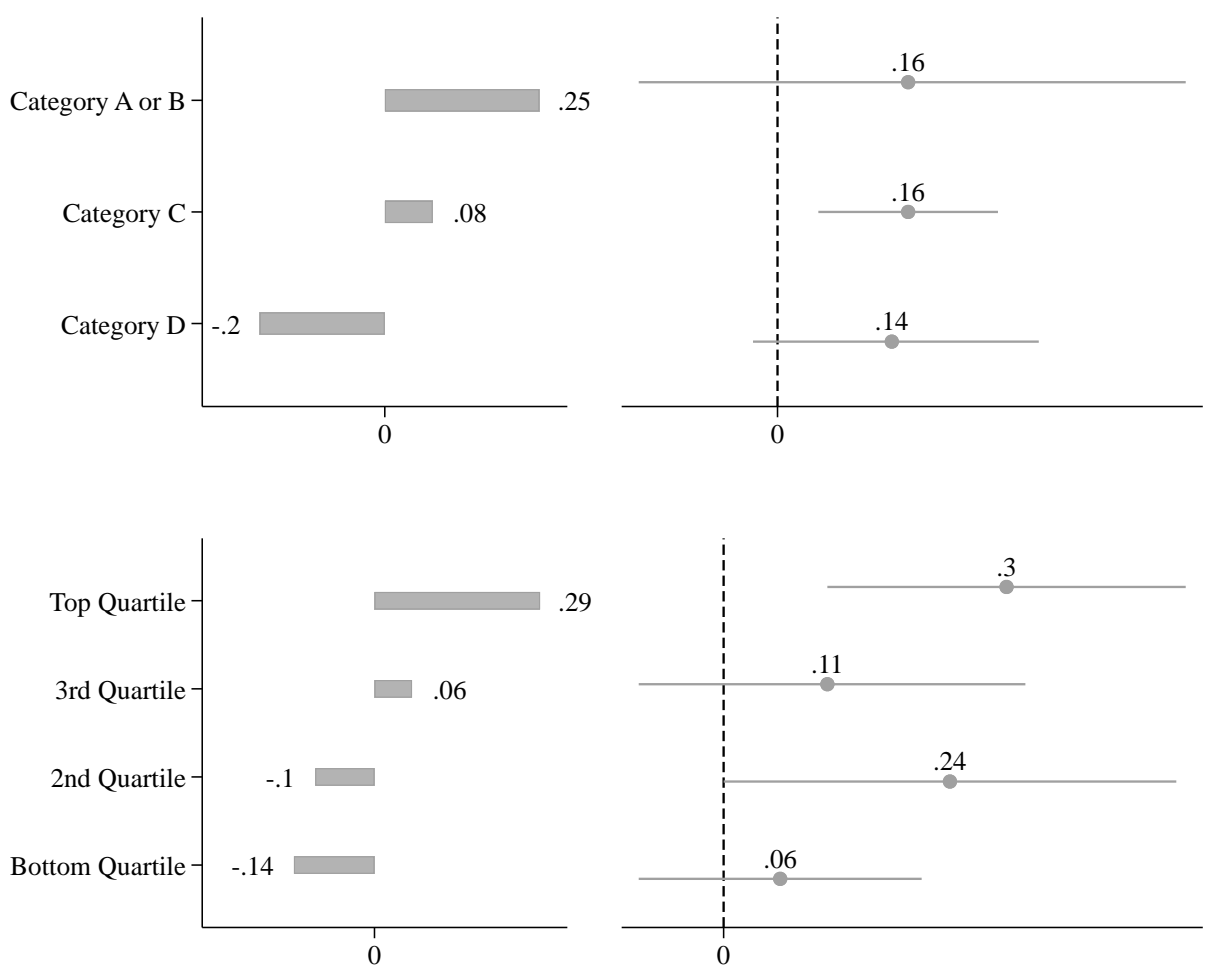

Notes: Cognitive skills data from test administered at 2013 survey. Left half of graph shows control means; right half shows treatment effect. Top panel shows results by how selective schools are. We have few A and B schools (most selective) in our sample since we sampled rural day schools. Bottom panel shows results by quartile of performance on the BECE exam. 
Figure A2: Effort Level on Cognitive Test "Games" by treatment status and gender, as assessed by surveyor (2013)

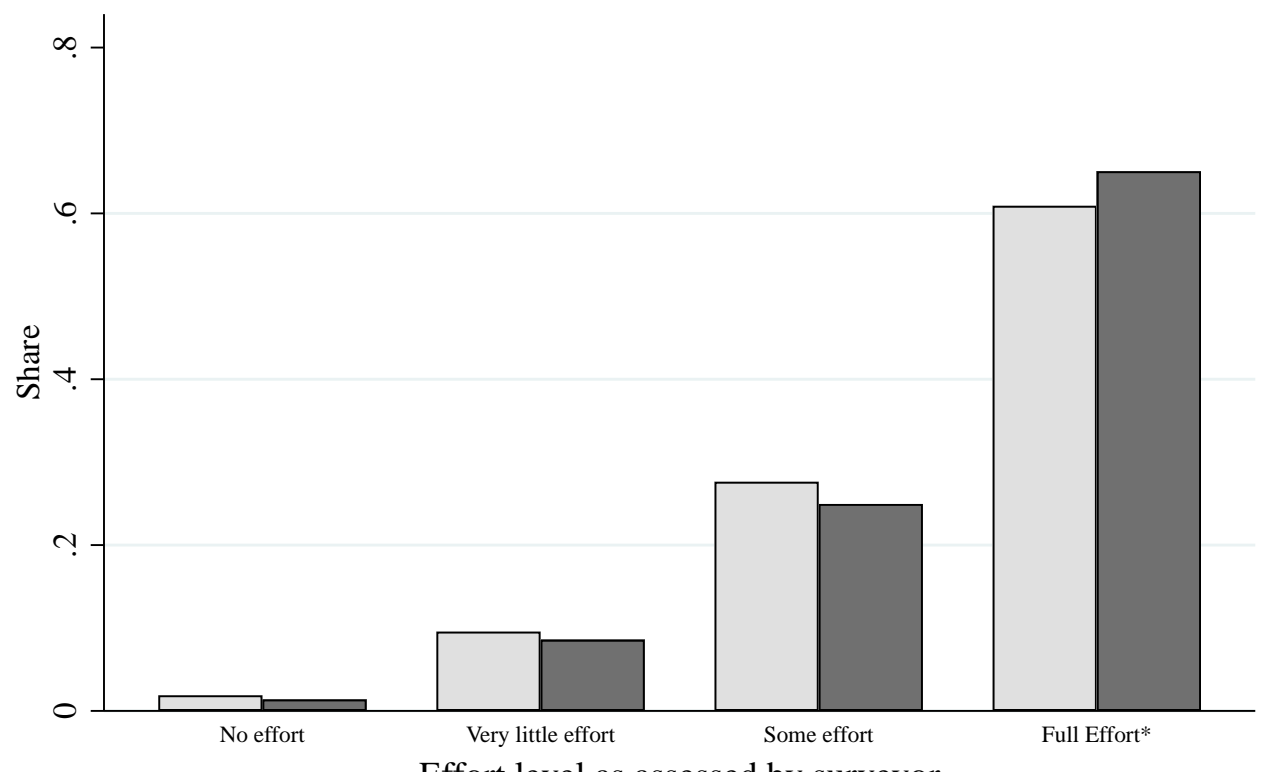

Effort level as assessed by surveyor
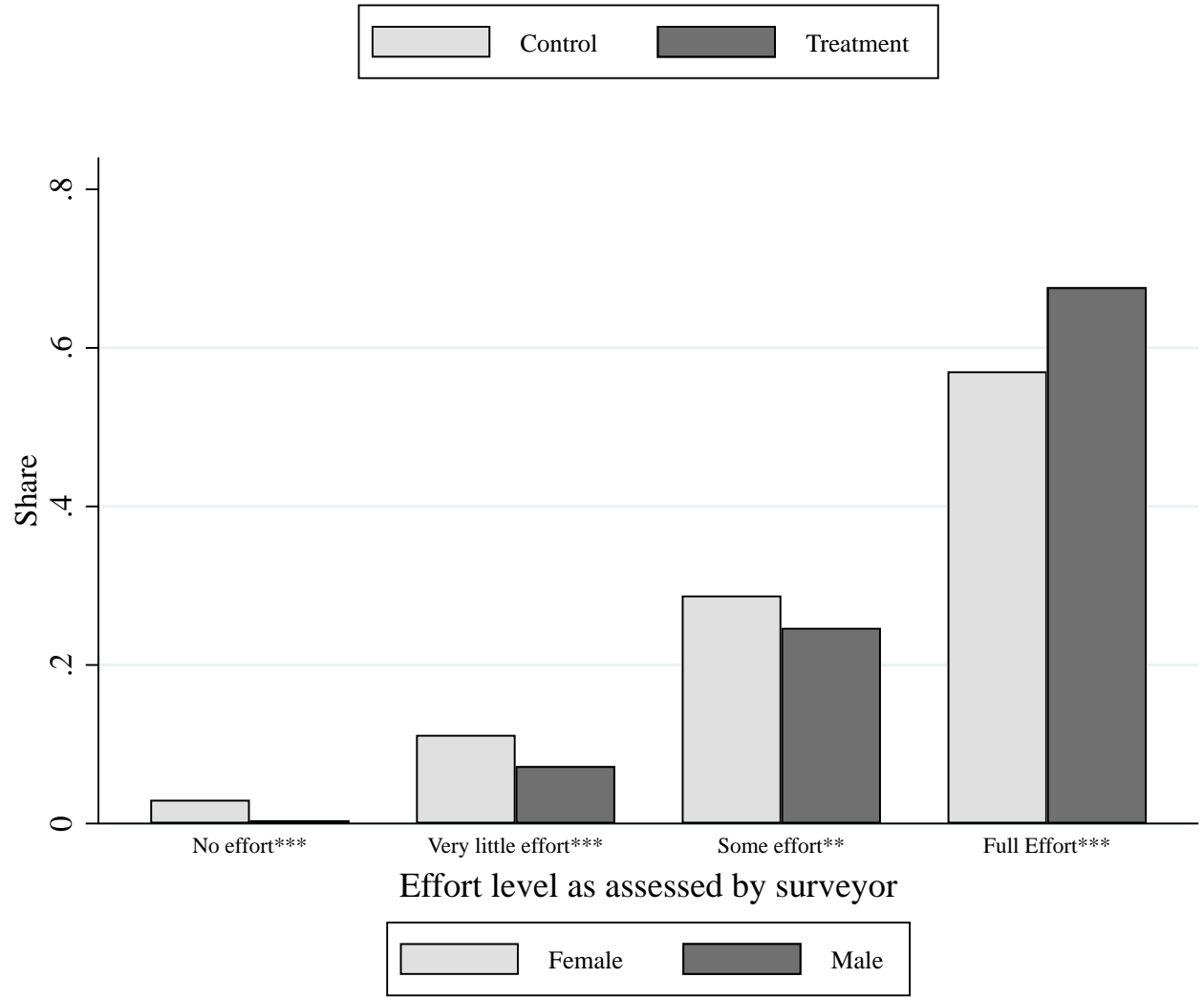

Notes: Data from 2013 in-person follow-up survey. The ${ }^{* * *}$ and $*$ on axis category labels reflect the p-values from the test of whether the group means of the given item are identical for treatment/control or male/female. ${ }^{* * *}$ signifies a p-value less than 0.01 and $*$ signifies a p-value less than 0.1 . 
Table A1: Attrition

\begin{tabular}{lccccccc}
\hline \hline & $(1)$ & $(2)$ & $(3)$ & $(4)$ & $(5)$ & $(6)$ & $(7)$ \\
& $\begin{array}{c}\text { Surveyed } \\
(2013)\end{array}$ & $\begin{array}{c}\text { Surveyed } \\
(2016)\end{array}$ & $\begin{array}{c}\text { Surveyed } \\
(2017)\end{array}$ & $\begin{array}{c}\text { Surveyed } \\
(2019)\end{array}$ & $\begin{array}{c}\text { Surveyed } \\
(2020)\end{array}$ & $\begin{array}{c}\text { Refused } \\
(2019)\end{array}$ & $\begin{array}{c}\text { Deceased } \\
(2019)\end{array}$ \\
\hline Panel $\boldsymbol{A}$ : $\boldsymbol{A l l}$ & & & & & & & \\
Treatment & -0.005 & 0.009 & 0.001 & 0.020 & 0.049 & -0.017 & 0.004 \\
& $(0.009)$ & $(0.008)$ & $(0.010)$ & $(0.010)$ & $(0.016)$ & $(0.005)$ & $(0.006)$ \\
P-value & 0.608 & 0.263 & 0.882 & 0.045 & 0.003 & 0.001 & 0.537 \\
Comparison mean & 0.963 & 0.964 & 0.954 & 0.939 & 0.826 & 0.025 & 0.014 \\
N & 2064 & 2064 & 2064 & 2064 & 2064 & 2064 & 2064 \\
& & & & & & & \\
Panel B: Female & & & & & & & \\
Treatment & 0.001 & 0.007 & -0.013 & 0.014 & 0.056 & -0.017 & 0.006 \\
& $(0.012)$ & $(0.011)$ & $(0.013)$ & $(0.013)$ & $(0.024)$ & $(0.008)$ & $(0.006)$ \\
P-value & 0.926 & 0.487 & 0.325 & 0.301 & 0.020 & 0.032 & 0.346 \\
Comparison mean & 0.967 & 0.970 & 0.967 & 0.947 & 0.809 & 0.027 & 0.006 \\
N & 1036 & 1036 & 1036 & 1036 & 1036 & 1036 & 1036 \\
& & & & & & & \\
Panel C: Male & & & & & & & \\
Treatment & -0.011 & 0.011 & 0.016 & 0.025 & 0.040 & -0.016 & 0.001 \\
P-value & $(0.014)$ & $(0.012)$ & $(0.014)$ & $(0.015)$ & $(0.022)$ & $(0.007)$ & $(0.010)$ \\
Comparison mean & 0.440 & 0.379 & 0.275 & 0.087 & 0.074 & 0.020 & 0.913 \\
N & 0.959 & 0.957 & 0.941 & 0.931 & 0.843 & 0.022 & 0.022 \\
P-val male=fem & 1028 & 1028 & 1028 & 1028 & 1028 & 1028 & 1028 \\
\hline \hline Notes: See Table 2 notes. There were no new deaths between 2019 and 2020. & & & \\
& 0.558 & 0.773 & 0.127 & 0.557 & 0.722 & 0.887 & 0.677 \\
\hline
\end{tabular}

Notes: See Table 2 notes. There were no new deaths between 2019 and 2020. 
Table A2: P-values and Sharpened q-values

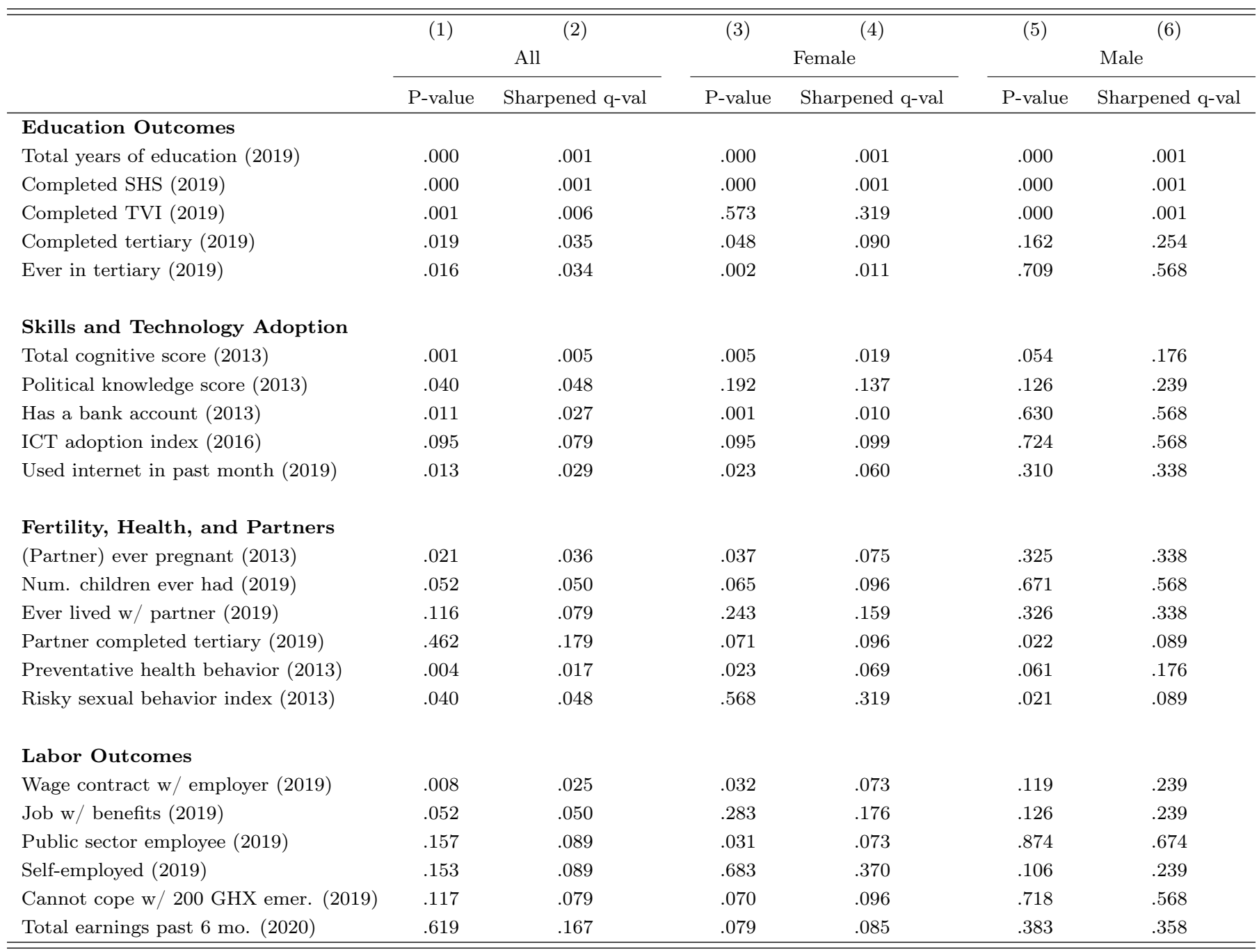

Notes: Year of survey in parentheses. See Table 2 notes for description of controls. Columns 1, 3, and 5 show the p-value for the sharpened form estimate of the treatment effect; columns 2, 4, and 6 show the sharpened q values, which account for false discovery rate given that there are 22 outcome variables in use (Benjamini, Krieger, and Yekutieli, 2006). See Table 2 for description of education outcomes, Table 3 for description of skills and technology adoption outcomes, Tables 5 and A7 for description of fertility, health behavior, and partner outcomes, and Table 6 for labor outcomes. 
Table A3: Additional Sample Characteristics at Baseline

\begin{tabular}{|c|c|c|c|c|}
\hline & $\begin{array}{c}(1) \\
\text { Completed } \\
\text { BECE } \\
\text { in } 2007\end{array}$ & $\begin{array}{c}(2) \\
\text { Perceived } \\
\text { returns } \\
\text { to SHS } \\
>100 \%\end{array}$ & $\begin{array}{c}\text { Ever } \\
\text { had sex }\end{array}$ & $\begin{array}{c}(4) \\
\text { Self-reported } \\
\text { financial } \\
\text { situation, } 1-5 \\
(5=\text { very poor })\end{array}$ \\
\hline \multicolumn{5}{|l|}{ Panel A: All } \\
\hline Treatment & $\begin{array}{c}0.005 \\
(0.016)\end{array}$ & $\begin{array}{c}0.008 \\
(0.025)\end{array}$ & $\begin{array}{l}-0.027 \\
(0.022)\end{array}$ & $\begin{array}{c}0.044 \\
(0.032)\end{array}$ \\
\hline P-value & 0.767 & 0.740 & 0.218 & 0.168 \\
\hline Comparison mean & 0.139 & 0.463 & 0.328 & 3.890 \\
\hline $\mathrm{N}$ & 2064 & 1782 & 2061 & 2046 \\
\hline \multicolumn{5}{|l|}{ Panel B: Female } \\
\hline Treatment & $\begin{array}{c}0.020 \\
(0.030)\end{array}$ & $\begin{array}{c}0.000 \\
(0.036)\end{array}$ & $\begin{array}{l}-0.001 \\
(0.033)\end{array}$ & $\begin{array}{c}0.019 \\
(0.044)\end{array}$ \\
\hline $\mathrm{P}$-value & 0.514 & 0.990 & 0.981 & 0.668 \\
\hline Comparison mean & 0.274 & 0.478 & 0.454 & 3.845 \\
\hline $\mathrm{N}$ & 1036 & 874 & 1034 & 1031 \\
\hline \multicolumn{5}{|l|}{ Panel C: Male } \\
\hline Treatment & $\begin{array}{c}0.000 \\
(.)\end{array}$ & $\begin{array}{c}0.017 \\
(0.035)\end{array}$ & $\begin{array}{l}-0.044 \\
(0.025)\end{array}$ & $\begin{array}{c}0.064 \\
(0.045)\end{array}$ \\
\hline P-value & . & 0.619 & 0.072 & 0.156 \\
\hline Comparison mean & 0.000 & 0.448 & 0.199 & 3.936 \\
\hline $\mathrm{N}$ & 1028 & 908 & 1027 & 1015 \\
\hline
\end{tabular}

Notes: See Table 1 notes. 
Table A4: Additional Education Outcomes

\begin{tabular}{|c|c|c|c|c|c|c|c|}
\hline & $\begin{array}{c}(1) \\
\text { Ever an } \\
\text { apprentice } \\
(2017)\end{array}$ & $\begin{array}{c}(2) \\
\text { Completed } \\
\text { apprenticeship } \\
(2017)\end{array}$ & $\begin{array}{c}(3) \\
\text { Ever } \\
\text { enrolled } \\
\text { in SHS } \\
(2019)\end{array}$ & $\begin{array}{c}\text { Currently } \\
\text { an apprentice } \\
(2019)\end{array}$ & $\begin{array}{c}(5) \\
\text { Currently } \\
\text { enrolled in } \\
\text { tertiary } \\
(2020)\end{array}$ & $\begin{array}{c}\text { (6) } \\
\text { Completed } \\
\text { tertiary } \\
(2020)\end{array}$ & $\begin{array}{c}(7) \\
\text { Enrolled } \\
\text { in formal } \\
\text { study/training } \\
(2019)\end{array}$ \\
\hline \multicolumn{8}{|l|}{ Panel A: All } \\
\hline Treatment & $\begin{array}{l}-0.141 \\
(0.023)\end{array}$ & $\begin{array}{l}-0.080 \\
(0.018)\end{array}$ & $\begin{array}{c}0.260 \\
(0.022)\end{array}$ & $\begin{array}{l}-0.011 \\
(0.012)\end{array}$ & $\begin{array}{c}0.019 \\
(0.012)\end{array}$ & $\begin{array}{c}0.049 \\
(0.018)\end{array}$ & $\begin{array}{c}0.015 \\
(0.012)\end{array}$ \\
\hline P-value & 0.000 & 0.000 & 0.000 & 0.399 & 0.099 & 0.006 & 0.203 \\
\hline Comparison mean & 0.440 & 0.222 & 0.459 & 0.080 & 0.044 & 0.117 & 0.054 \\
\hline $\mathrm{N}$ & 1967 & 1967 & 1952 & 1951 & 1734 & 1742 & 1951 \\
\hline \multicolumn{8}{|l|}{ Panel B: Female } \\
\hline Treatment & $\begin{array}{l}-0.143 \\
(0.031)\end{array}$ & $\begin{array}{l}-0.070 \\
(0.023)\end{array}$ & $\begin{array}{c}0.257 \\
(0.032)\end{array}$ & $\begin{array}{l}-0.032 \\
(0.017)\end{array}$ & $\begin{array}{c}0.021 \\
(0.016)\end{array}$ & $\begin{array}{c}0.077 \\
(0.025)\end{array}$ & $\begin{array}{c}0.032 \\
(0.016)\end{array}$ \\
\hline P-value & 0.000 & 0.003 & 0.000 & 0.062 & 0.191 & 0.002 & 0.048 \\
\hline Comparison mean & 0.409 & 0.184 & 0.403 & 0.087 & 0.037 & 0.100 & 0.041 \\
\hline $\mathrm{N}$ & 996 & 996 & 986 & 986 & 854 & 857 & 986 \\
\hline \multicolumn{8}{|l|}{ Panel C: Male } \\
\hline Treatment & $\begin{array}{c}-0.142 \\
(0.032)\end{array}$ & $\begin{array}{c}-0.092 \\
(0.027)\end{array}$ & $\begin{array}{c}0.257 \\
(0.030)\end{array}$ & $\begin{array}{c}0.011 \\
(0.018)\end{array}$ & $\begin{array}{c}0.018 \\
(0.017)\end{array}$ & $\begin{array}{c}0.022 \\
(0.025)\end{array}$ & $\begin{array}{l}-0.003 \\
(0.017)\end{array}$ \\
\hline P-value & 0.000 & 0.001 & 0.000 & 0.550 & 0.285 & 0.385 & 0.875 \\
\hline Comparison mean & 0.473 & 0.262 & 0.518 & 0.073 & 0.051 & 0.134 & 0.068 \\
\hline $\mathrm{N}$ & 971 & 971 & 966 & 965 & 880 & 885 & 965 \\
\hline P-val male $=$ fem & 0.959 & 0.519 & 0.917 & 0.085 & 0.827 & 0.136 & 0.145 \\
\hline
\end{tabular}

Notes: See Table 2 notes. 
Table A5: Education Plan Outcomes

\begin{tabular}{|c|c|c|c|c|c|c|}
\hline & $\begin{array}{c}\quad(1) \\
\text { Plans to } \\
\text { apply to } \\
\text { tertiary } \\
(2013) \\
\end{array}$ & $\begin{array}{c}(2) \\
\text { Plans to } \\
\text { apply to } \\
\text { tertiary } \\
(2017) \\
\end{array}$ & $\begin{array}{c}(3) \\
\text { Plans to apply } \\
\text { as Mature } \\
\text { Applicant } \\
(2017) \\
\end{array}$ & $\begin{array}{c}(4) \\
\text { Sat for } \\
\text { WASSCE } \\
\text { exam } \\
(2019) \\
\end{array}$ & $\begin{array}{c}(5) \\
\text { Applied } \\
\text { as Mature } \\
\text { Applicant } \\
(2019) \\
\end{array}$ & $\begin{array}{l}(6) \\
\text { Plans to } \\
\text { apply to } \\
\text { tertiary } \\
(2019)\end{array}$ \\
\hline \multicolumn{7}{|l|}{ Panel A: All } \\
\hline Treatment & $\begin{array}{c}0.241 \\
(0.023)\end{array}$ & $\begin{array}{c}0.150 \\
(0.023)\end{array}$ & $\begin{array}{c}0.098 \\
(0.024)\end{array}$ & $\begin{array}{c}0.263 \\
(0.022)\end{array}$ & $\begin{array}{c}0.012 \\
(0.008)\end{array}$ & $\begin{array}{c}0.149 \\
(0.024)\end{array}$ \\
\hline $\mathrm{P}$-value & 0.000 & 0.000 & 0.000 & 0.000 & 0.124 & 0.000 \\
\hline Comparison mean & 0.430 & 0.489 & 0.384 & 0.464 & 0.020 & 0.366 \\
\hline $\mathrm{N}$ & 1979 & 1970 & 1970 & 1952 & 1952 & 1952 \\
\hline \multicolumn{7}{|l|}{ Panel B: Female } \\
\hline Treatment & $\begin{array}{c}0.268 \\
(0.032)\end{array}$ & $\begin{array}{c}0.150 \\
(0.033)\end{array}$ & $\begin{array}{c}0.122 \\
(0.033)\end{array}$ & $\begin{array}{c}0.261 \\
(0.032)\end{array}$ & $\begin{array}{c}0.014 \\
(0.011)\end{array}$ & $\begin{array}{c}0.179 \\
(0.033)\end{array}$ \\
\hline $\mathrm{P}$-value & 0.000 & 0.000 & 0.000 & 0.000 & 0.221 & 0.000 \\
\hline Comparison mean & 0.363 & 0.427 & 0.337 & 0.403 & 0.018 & 0.286 \\
\hline $\mathrm{N}$ & 1001 & 997 & 997 & 986 & 986 & 986 \\
\hline \multicolumn{7}{|l|}{ Panel C: Male } \\
\hline Treatment & $\begin{array}{c}0.211 \\
(0.032)\end{array}$ & $\begin{array}{c}0.144 \\
(0.032)\end{array}$ & $\begin{array}{c}0.073 \\
(0.034)\end{array}$ & $\begin{array}{c}0.259 \\
(0.030)\end{array}$ & $\begin{array}{c}0.011 \\
(0.012)\end{array}$ & $\begin{array}{c}0.114 \\
(0.034)\end{array}$ \\
\hline P-value & 0.000 & 0.000 & 0.032 & 0.000 & 0.356 & 0.001 \\
\hline Comparison mean & 0.500 & 0.555 & 0.434 & 0.528 & 0.022 & 0.450 \\
\hline $\mathrm{N}$ & 978 & 973 & 973 & 966 & 966 & 966 \\
\hline P-val male $=$ fem & 0.240 & 0.879 & 0.294 & 0.935 & 0.883 & 0.169 \\
\hline
\end{tabular}

Notes: See Table 2 notes. 
Table A6: Additional Cognition Outcomes

\begin{tabular}{|c|c|c|c|c|c|}
\hline & $\begin{array}{c}(1) \\
\text { Reading } \\
\text { test } \\
\text { score } \\
(2013)\end{array}$ & $\begin{array}{c}(2) \\
\text { Math } \\
\text { test } \\
\text { score } \\
(2013)\end{array}$ & $\begin{array}{c}(3) \\
\text { Memory for } \\
\text { digit span } \\
\text { (forward) } \\
(2013)\end{array}$ & $\begin{array}{c}(4) \\
\text { Memory for } \\
\text { digit span } \\
\text { (backward) } \\
(2013)\end{array}$ & $\begin{array}{c}(5) \\
\text { Raven's } \\
\text { progressive } \\
\text { matrices } \\
(2013)\end{array}$ \\
\hline \multicolumn{6}{|l|}{ Panel A: All } \\
\hline Treatment & $\begin{array}{c}0.143 \\
(0.044)\end{array}$ & $\begin{array}{c}0.125 \\
(0.046)\end{array}$ & $\begin{array}{c}0.009 \\
(0.120)\end{array}$ & $\begin{array}{c}0.109 \\
(0.086)\end{array}$ & $\begin{array}{l}-0.001 \\
(0.119)\end{array}$ \\
\hline P-value & 0.001 & 0.007 & 0.942 & 0.207 & 0.993 \\
\hline Comparison mean & -0.000 & -0.000 & 7.544 & 4.541 & 6.954 \\
\hline $\mathrm{N}$ & 1983 & 1983 & 1983 & 1983 & 1981 \\
\hline \multicolumn{6}{|l|}{ Panel B: Female } \\
\hline Treatment & $\begin{array}{c}0.159 \\
(0.066)\end{array}$ & $\begin{array}{c}0.170 \\
(0.067)\end{array}$ & $\begin{array}{l}-0.025 \\
(0.170)\end{array}$ & $\begin{array}{c}0.045 \\
(0.118)\end{array}$ & $\begin{array}{l}-0.041 \\
(0.168)\end{array}$ \\
\hline P-value & 0.017 & 0.012 & 0.882 & 0.703 & 0.808 \\
\hline Comparison mean & -0.096 & -0.191 & 7.381 & 4.374 & 6.558 \\
\hline N & 1002 & 1002 & 1002 & 1002 & 1001 \\
\hline \multicolumn{6}{|l|}{ Panel C: Male } \\
\hline Treatment & $\begin{array}{c}0.129 \\
(0.058)\end{array}$ & $\begin{array}{c}0.069 \\
(0.060)\end{array}$ & $\begin{array}{c}0.037 \\
(0.170)\end{array}$ & $\begin{array}{c}0.158 \\
(0.125)\end{array}$ & $\begin{array}{c}0.019 \\
(0.165)\end{array}$ \\
\hline P-value & 0.026 & 0.254 & 0.826 & 0.207 & 0.907 \\
\hline Comparison mean & 0.100 & 0.199 & 7.714 & 4.714 & 7.368 \\
\hline $\mathrm{N}$ & 981 & 981 & 981 & 981 & 980 \\
\hline$P$-val male $=$ fem & 0.789 & 0.246 & 0.801 & 0.518 & 0.940 \\
\hline
\end{tabular}

Notes: See Table 2 notes. Reading test score consists of: can read sentence aloud, can read paragraph well (as rated by surveyor), each of: basic, intermediate, and advanced comprehension, and fact identification. Math test score consists of: two basic computations, basic calculator computation, numeracy, two levels of profit calculation questions, identifying mode, calculating sums without help, calculating sums with explanation, calculating percentage, and an exchange rate calculation. Both reading and math test scores are standardized. 
Table A7: Additional Fertility, Partners and Health Behavior Outcomes

\begin{tabular}{|c|c|c|c|c|c|c|c|c|}
\hline & (1) & (2) & $(3)$ & $(4)$ & $(5)$ & $(6)$ & $(7)$ & (8) \\
\hline & $\begin{array}{c}\text { Desired } \\
\text { fertility: } \\
\# \text { of } \\
\text { children } \\
\text { by age } 50 \\
(2013)\end{array}$ & $\begin{array}{l}\text { Preventive } \\
\text { health } \\
\text { behavior } \\
\text { Index } \\
(2013)\end{array}$ & $\begin{array}{c}\text { Risky sexual } \\
\text { behavior/STI } \\
\text { exposure } \\
\text { index } \\
\text { safe }->\text { risky } \\
(2013)\end{array}$ & $\begin{array}{c}\text { Used } \\
\text { prenatal } \\
\text { care for } \\
\text { last } \\
\text { pregnancy } \\
(2019)\end{array}$ & $\begin{array}{l}\text { Knowledge } \\
\text { about } \\
\text { COVID-19 } \\
\text { Index } \\
(2020)\end{array}$ & $\begin{array}{l}\text { Self-reported } \\
\text { COVID-19 } \\
\text { social } \\
\text { distancing } \\
\text { Index } \\
(2020)\end{array}$ & $\begin{array}{c}\text { Still } \\
\text { living } \\
\text { with } \\
\text { parents } \\
(2020)\end{array}$ & $\begin{array}{c}\text { Currently } \\
\text { married } \\
\text { or } \\
\text { cohabitating } \\
(2020)\end{array}$ \\
\hline \multicolumn{9}{|l|}{ Panel A: All } \\
\hline Treatment & $\begin{array}{l}-0.025 \\
(0.048)\end{array}$ & $\begin{array}{c}0.105 \\
(0.037)\end{array}$ & $\begin{array}{l}-0.047 \\
(0.023)\end{array}$ & $\begin{array}{c}0.009 \\
(0.007)\end{array}$ & $\begin{array}{l}-0.023 \\
(0.023)\end{array}$ & $\begin{array}{c}0.009 \\
(0.026)\end{array}$ & $\begin{array}{c}0.052 \\
(0.021)\end{array}$ & $\begin{array}{l}-0.053 \\
(0.025)\end{array}$ \\
\hline P-value & 0.609 & 0.004 & 0.040 & 0.234 & 0.330 & 0.738 & 0.013 & 0.033 \\
\hline Comparison mean & 3.629 & 1.624 & 0.001 & 0.982 & -0.006 & -0.002 & 0.190 & 0.432 \\
\hline $\mathrm{N}$ & 1978 & 1984 & 1980 & 970 & 1737 & 1737 & 1737 & 1731 \\
\hline \multicolumn{9}{|l|}{ Panel B: Female } \\
\hline Treatment & $\begin{array}{l}-0.045 \\
(0.064)\end{array}$ & $\begin{array}{c}0.119 \\
(0.052)\end{array}$ & $\begin{array}{l}-0.017 \\
(0.030)\end{array}$ & $\begin{array}{c}0.011 \\
(0.005)\end{array}$ & $\begin{array}{l}-0.006 \\
(0.034)\end{array}$ & $\begin{array}{l}-0.044 \\
(0.036)\end{array}$ & $\begin{array}{c}0.061 \\
(0.032)\end{array}$ & $\begin{array}{l}-0.096 \\
(0.036)\end{array}$ \\
\hline P-value & 0.486 & 0.023 & 0.568 & 0.027 & 0.867 & 0.222 & 0.056 & 0.008 \\
\hline Comparison mean & 3.639 & 1.691 & 0.095 & 0.989 & -0.061 & 0.060 & 0.220 & 0.533 \\
\hline $\mathrm{N}$ & 999 & 1002 & 1000 & 642 & 856 & 856 & 856 & 853 \\
\hline \multicolumn{9}{|l|}{ Panel C: Male } \\
\hline Treatment & $\begin{array}{l}-0.006 \\
(0.072)\end{array}$ & $\begin{array}{c}0.096 \\
(0.051)\end{array}$ & $\begin{array}{l}-0.076 \\
(0.033)\end{array}$ & $\begin{array}{c}0.010 \\
(0.019)\end{array}$ & $\begin{array}{l}-0.041 \\
(0.032)\end{array}$ & $\begin{array}{c}0.061 \\
(0.037)\end{array}$ & $\begin{array}{c}0.046 \\
(0.027)\end{array}$ & $\begin{array}{l}-0.008 \\
(0.033)\end{array}$ \\
\hline P-value & 0.937 & 0.061 & 0.021 & 0.595 & 0.198 & 0.097 & 0.097 & 0.805 \\
\hline Comparison mean & 3.619 & 1.555 & -0.098 & 0.967 & 0.049 & -0.063 & 0.161 & 0.333 \\
\hline $\mathrm{N}$ & 979 & 982 & 980 & 328 & 881 & 881 & 881 & 878 \\
\hline $\mathrm{P}$-val male $=$ fem & 0.751 & 0.848 & 0.172 & 0.830 & 0.502 & 0.039 & 0.675 & 0.078 \\
\hline
\end{tabular}

Notes: See Table 2 notes. Preventive health behavior index is comprised of the following questions: do you sleep under an insecticidetreated net, do you use other mosquito protection, and did you use water and soap the last time you washed your hands. Index of risky sexual behavior and STI exposure (2013) is comprised of the following variables: have you ever had sex, age when first had sex, number of sexual partners in past 6 months, number of lifetime sexual partners, were you ever in a relationship with someone more than 20 years older, were you ever in a relationship for gifts or money, have you ever had sex with a commercial sex worker, did you use contraception the last time you had sex, have you ever used contraception when having sex, do you ever do anything to protect yourself from getting infected with HIV/AIDs, have you had a sexually transmitted infection in the past 12 months, has partner ever told you that they had a sexually transmitted infection, did you change how often you had sex after learning that partner was infected with STI. The COVID knowledge index is composed of: number of each COVID facts, symptoms, precautions, and modes of spread could identify, whether knows number of COVID deaths in Ghana, whether knows country of COVID origin, and whether knew especially COVID-vulnerable groups. The COVID social distancing index is comprised of: number of precautions taken, whether going to crowded places, whether did not leave house, number of people met in last 2 days, and whether used public transport. For COVID knowledge index and social distancing index, controls also include week of survey. 
Table A8: 2017 Labor Market Outcomes

\begin{tabular}{|c|c|c|c|c|c|}
\hline & (1) & (2) & (3) & (4) & (5) \\
\hline & $\begin{array}{c}\text { Worked } \\
\text { for pay } \\
\text { in past } \\
6 \text { months } \\
(2017)\end{array}$ & $\begin{array}{c}\text { Public } \\
\text { sector } \\
\text { employee } \\
(2017)\end{array}$ & $\begin{array}{c}\text { Has wage } \\
\text { contract } \\
\text { with } \\
\text { employer } \\
(2017)\end{array}$ & $\begin{array}{c}\text { Job } \\
\text { with } \\
\text { benefits } \\
(2017)\end{array}$ & $\begin{array}{c}\text { Self- } \\
\text { employed } \\
(2017)\end{array}$ \\
\hline \multicolumn{6}{|l|}{ Panel A: All } \\
\hline Treatment & $\begin{array}{c}0.031 \\
(0.021)\end{array}$ & $\begin{array}{c}0.032 \\
(0.010)\end{array}$ & $\begin{array}{c}0.033 \\
(0.013)\end{array}$ & $\begin{array}{c}0.045 \\
(0.015)\end{array}$ & $\begin{array}{l}-0.050 \\
(0.020)\end{array}$ \\
\hline P-value & 0.131 & 0.002 & 0.013 & 0.003 & 0.012 \\
\hline Comparison mean & 0.733 & 0.026 & 0.061 & 0.084 & 0.255 \\
\hline $\mathrm{N}$ & 1970 & 1968 & 1968 & 1968 & 1968 \\
\hline \multicolumn{6}{|l|}{ Panel B: Female } \\
\hline Treatment & $\begin{array}{c}0.021 \\
(0.033)\end{array}$ & $\begin{array}{c}0.041 \\
(0.015)\end{array}$ & $\begin{array}{c}0.025 \\
(0.018)\end{array}$ & $\begin{array}{c}0.042 \\
(0.020)\end{array}$ & $\begin{array}{l}-0.076 \\
(0.030)\end{array}$ \\
\hline P-value & 0.516 & 0.005 & 0.166 & 0.035 & 0.010 \\
\hline Comparison mean & 0.629 & 0.021 & 0.058 & 0.066 & 0.305 \\
\hline $\mathrm{N}$ & 997 & 996 & 996 & 996 & 996 \\
\hline \multicolumn{6}{|l|}{ Panel C: Male } \\
\hline Treatment & $\begin{array}{c}0.031 \\
(0.023)\end{array}$ & $\begin{array}{c}0.023 \\
(0.014)\end{array}$ & $\begin{array}{c}0.040 \\
(0.020)\end{array}$ & $\begin{array}{c}0.046 \\
(0.023)\end{array}$ & $\begin{array}{l}-0.020 \\
(0.027)\end{array}$ \\
\hline P-value & 0.188 & 0.108 & 0.043 & 0.048 & 0.452 \\
\hline Comparison mean & 0.844 & 0.031 & 0.064 & 0.103 & 0.202 \\
\hline $\mathrm{N}$ & 973 & 972 & 972 & 972 & 972 \\
\hline $\mathrm{P}$-val male $=\mathrm{fem}$ & 0.835 & 0.385 & 0.566 & 0.894 & 0.146 \\
\hline
\end{tabular}

Notes: See Table 2 notes. 
Table A9: Earnings Bounds for females not induced by the program to still be in tertiary

\begin{tabular}{lcc}
\hline \hline & \multicolumn{2}{c}{ Total earnings last 6 mo. (GHX) } \\
\cline { 2 - 3 } & $(1)$ & $(2)$ \\
& Lower bound & Upper bound \\
\hline Panel A: 2017 & & \\
Treatment & 80.19 & 249.87 \\
& $(78.69)$ & $(72.66)$ \\
P-value & 0.308 & 0.001 \\
Comparison mean & 647.49 & 647.49 \\
N & 969 & 866 \\
& & \\
Panel B: 2019 & & \\
Treatment & 35.79 & 251.52 \\
& $(108.46)$ & $(101.78)$ \\
P-value & 0.741 & 0.014 \\
Comparison mean & 951.46 & 951.46 \\
N & 972 & 916 \\
& & \\
Panel C: 2020 & & \\
Treatment & 262.98 & 377.81 \\
P-value & $(149.38)$ & $(130.41)$ \\
Comparison mean & 0.079 & 0.004 \\
N & 1008.08 & 1008.08 \\
\hline \hline
\end{tabular}

Notes: See Table 2 notes for controls. Panel A shows results for 2019; Panel B for 2019; Panel C for 2020. We only compute bounds for females since there is no differential tertiary enrollment for males. Bounds are calculated in the following way: Let $\mathrm{X}$ be the treatment effect on currently attending tertiary school. For upper bounds, top X\% of control earners removed. All respondents currently enrolled in tertiary removed for bounds calculations. Lower bounds are the treatment effects shown in Table 6 . 
Table A10: Impact of Scholarship on Mental Health and Satisfaction

\begin{tabular}{|c|c|c|c|c|c|c|c|}
\hline & (1) & (2) & $(3)$ & (4) & (5) & (6) & $(7)$ \\
\hline & $\begin{array}{c}\text { Mental } \\
\text { health } \\
\text { index } \\
1-5 \\
(1=\text { depressed }) \\
(2013)\end{array}$ & $\begin{array}{c}\text { Satisfaction } \\
\text { index } \\
1-5 \\
(1=\text { very } \\
\text { unsatisfied }) \\
(2013)\end{array}$ & $\begin{array}{c}\text { If employed: } \\
\text { job } \\
\text { satisfaction } \\
1-5 \\
(1=\text { very } \\
\text { unsatisfied }) \\
(2017)\end{array}$ & $\begin{array}{c}\text { Confident } \\
\text { can get } \\
\text { better job } \\
1-5 \text { ( } 5=\text { very } \\
\text { confident) } \\
(2017)\end{array}$ & $\begin{array}{c}\text { If employed: } \\
\text { job } \\
\text { satisfaction } \\
1-5 \text { (1=very } \\
\text { unsatisfied) } \\
(2019)\end{array}$ & $\begin{array}{c}\text { Actively } \\
\text { searching } \\
\text { for } \\
\text { job } \\
(2019)\end{array}$ & $\begin{array}{c}\text { If has } \\
\text { earnings: } \\
\text { actively } \\
\text { searching } \\
\text { for } \\
\text { a job } \\
(2019)\end{array}$ \\
\hline \multicolumn{8}{|l|}{ Panel A: All } \\
\hline Treatment & $\begin{array}{l}-0.002 \\
(0.048)\end{array}$ & $\begin{array}{l}-0.001 \\
(0.038)\end{array}$ & $\begin{array}{l}-0.196 \\
(0.084)\end{array}$ & $\begin{array}{c}0.071 \\
(0.030)\end{array}$ & $\begin{array}{l}-0.195 \\
(0.077)\end{array}$ & $\begin{array}{c}0.075 \\
(0.022)\end{array}$ & $\begin{array}{c}0.092 \\
(0.027)\end{array}$ \\
\hline P-value & 0.968 & 0.972 & 0.020 & 0.018 & 0.011 & 0.001 & 0.001 \\
\hline Comparison mean & -0.000 & 3.318 & 3.773 & 4.811 & 3.750 & 0.242 & 0.197 \\
\hline $\mathrm{N}$ & 1981 & 1981 & 1218 & 1221 & 1286 & 1952 & 1172 \\
\hline \multicolumn{8}{|l|}{ Panel B: Female } \\
\hline Treatment & $\begin{array}{l}-0.019 \\
(0.065)\end{array}$ & $\begin{array}{c}0.097 \\
(0.052)\end{array}$ & $\begin{array}{l}-0.085 \\
(0.127)\end{array}$ & $\begin{array}{c}0.077 \\
(0.044)\end{array}$ & $\begin{array}{l}-0.143 \\
(0.120)\end{array}$ & $\begin{array}{c}0.085 \\
(0.030)\end{array}$ & $\begin{array}{c}0.144 \\
(0.039)\end{array}$ \\
\hline P-value & 0.775 & 0.062 & 0.501 & 0.080 & 0.234 & 0.004 & 0.000 \\
\hline Comparison mean & -0.037 & 3.310 & 3.819 & 4.814 & 3.761 & 0.198 & 0.115 \\
\hline $\mathrm{N}$ & 1001 & 1001 & 542 & 543 & 541 & 986 & 482 \\
\hline \multicolumn{8}{|l|}{ Panel C: Male } \\
\hline Treatment & $\begin{array}{c}0.013 \\
(0.069)\end{array}$ & $\begin{array}{l}-0.095 \\
(0.054)\end{array}$ & $\begin{array}{l}-0.266 \\
(0.113)\end{array}$ & $\begin{array}{c}0.066 \\
(0.040)\end{array}$ & $\begin{array}{l}-0.240 \\
(0.100)\end{array}$ & $\begin{array}{c}0.062 \\
(0.032)\end{array}$ & $\begin{array}{c}0.054 \\
(0.037)\end{array}$ \\
\hline P-value & 0.849 & 0.082 & 0.018 & 0.102 & 0.016 & 0.051 & 0.140 \\
\hline Comparison mean & 0.038 & 3.327 & 3.734 & 4.808 & 3.742 & 0.288 & 0.254 \\
\hline $\mathrm{N}$ & 980 & 980 & 676 & 678 & 745 & 966 & 690 \\
\hline$P$-val male $=$ fem & 0.828 & 0.012 & 0.291 & 0.868 & 0.531 & 0.619 & 0.083 \\
\hline
\end{tabular}

Notes: See Table 2 Notes. The mental health index consists of asking whether the respondent was each of the following in the past few days: bothered by usually unbothersome things, having trouble focusing, depressed, feeling that everything they did was an effort, hopeful about the future, fearful, and sleeping restlessly. The satisfaction index consists of the following: life satisfaction, financial satisfaction, and satisfaction of life compared to that of others. 


\section{Appendix A: Model Proofs}

\section{Proof of Proposition 1:}

(i) Given that the lower support of the shock in the skill production function is $\underline{\varepsilon}>\frac{1}{A_{h}}-S(1, \underline{a})-$ $\frac{\eta}{A_{h}}$, offspring's skill level will be at least $\frac{1-\underline{\eta}}{A_{h}}$. With effort of 1 , they can therefore have income higher than 1 in self-employment sector. This ensures that they equalize the marginal utility from consuming good 1 to 1 and consume positive quantity of good 2. They will therefore behave as if they are risk neutral.

The utility maximization problem faced by the offspring is:

$$
\begin{gathered}
\max _{\left\{e_{i}, x_{i}^{1}, x_{i}^{2}\right\}} \ln x_{i}^{1}+x_{i}^{2}-\frac{1}{2} e_{i}^{2}+\gamma_{g} h_{i} \\
\text { s.t. } x^{1}+x^{2} \leq E[w]
\end{gathered}
$$

Since this labor market is competitive, fixed costs in the competitive private sector are borne by the worker and hence expected wages in the competitive sectors are $E\left[w_{h}\right]=A_{h} S+e$ in selfemployment and $E\left[w_{p}\right]=A_{p} s+e-f_{p}$ in the private competitive sector. In the public sector, wage is fixed at $w_{g}=A_{p} s+\phi-f_{p}$. Solving the UMP gives rise to $e^{*}=1$ in the self-employment and competitive private sectors and $e^{*}=0$ in the public sector, as (i) states.

(ii) Moreover, optimum consumption of good 1 is 1 for all three sectors and maximum expected utilities are $E\left[u_{h}\right]^{*}=A_{h} s-\frac{1}{2}+\gamma_{g} h_{i}, E\left[u_{p}\right]^{*}=A_{p} s-f_{p}-\frac{1}{2}+\gamma_{g} h_{i}$ and $E\left[u_{g}\right]^{*}=A_{p} s+\phi-$ $f_{p}-1+\gamma_{g} h_{i}$, respectively.

A worker will therefore be indifferent between working in the self-employment and the competitive private sector if maximal expected utility is equalized, that is, $A_{h} s-\frac{1}{2}=A_{p} s-f_{p}-\frac{1}{2}$. So, highly skilled workers with skill $\mathrm{s}>\frac{f_{p}}{A_{p}-A_{h}}$ will prefer to work and be paid their marginal product in the competitive private sector to working in the self-employment sector while those with skill s $<\frac{f_{p}}{A_{p}-A_{h}}$ will choose self-employment. 
Highly skilled workers with skill $\mathrm{s}>\frac{f_{p}}{A_{p}-A_{h}}$ and tertiary education will prefer to work in the public sector. $\phi \geq \frac{1}{2}$ implies workers will always have higher utility in the public sector than in the private competitive sector, regardless of their skill level. This gives the result in (ii).

Proof of Proposition 2: (i) Let $\widehat{\Delta}_{i}\left(\hat{a}_{i}\right)=E\left[u_{i} \mid D_{i}=1\right]-E\left[u_{i} \mid D_{i}=0\right]$ denote the gain in perceived expected utility of the offspring if the household chooses to enroll them in secondary school.

Substituting the budget constraints in the objective function, we have that the household with a wealth level $y_{i} \geq 1+c$ will solve the following problem:

$$
\max _{\left\{D_{i}, x_{i 0}^{1}\right\}} \ln x_{i 0}^{1}+y_{i}-c_{i} D_{i}-x_{i o}^{1}+\lambda_{i g}\left(E\left[w_{i} \mid D_{i}=0\right]-\frac{3}{2}+\widehat{\Delta}_{i} D_{i}\right)
$$

As explained in the proof for Proposition 1, offspring will earn at least $w_{i}>1$ and hence will be consuming on the linear portion of their utility function. Their income therefore enters linearly in the parents' utility function. This condition seems reasonable since all the children in the sample completed primary education and scored well enough to pass the BECE exam and gain admission to secondary school, and since Ghana has experienced robust economic growth since 2017.

The first order conditions with respect to $x_{i o}^{1}$ is $x_{i o}^{1 *}=1$. This implies that the household with a wealth level $y_{i}>1+c_{i}$ will choose secondary education $D_{i}=1$ if and only if

$$
\begin{aligned}
\ln x_{i o}^{1 *}+y_{i}-c_{i}-x_{i o}^{1 *}+\lambda_{i g}\left(E\left[w_{i} \mid D_{i}=0\right]-\frac{3}{2}+\widehat{\Delta}_{i}\right) \\
\geq \ln x_{i o}^{1 *}+y_{i}-x_{i o}^{1 *}+\lambda_{i g}\left(E\left[w_{i} \mid D_{i}=0\right]-\frac{3}{2}\right)
\end{aligned}
$$

This simplifies to $\lambda_{i g} \widehat{\Delta}_{i} \geq c_{i}$.

Households with wealth level $1<y_{i}<1+c_{i}$ will have to choose between buying $x_{i o}^{1 *}=1$ and spending the rest on $x_{i o}^{2}$ or buying education and spending the rest on $x_{i o}^{1}$. Hence, $D_{i}=1$ if and only if

$$
\ln \left(y_{i}-c_{i}\right)+\lambda_{i g}\left(E\left[w_{i} \mid D_{i}=0\right]-\frac{3}{2}+\widehat{\Delta}_{i}\right) \geq \ln 1+y_{i}-1+\lambda_{i g}\left(E\left[w_{i} \mid D_{i}=0\right]-\frac{3}{2}\right)
$$


This simplifies to $\lambda_{i g} \widehat{\Delta}_{i} \geq y_{i}-1-\ln \left(y_{i}-c_{i}\right)$.

Households with $y_{i} \leq 1$ will be unable to consume in the region where their utility increases linearly, that is, they will be unable to consume any good 2. They will invest in secondary education if and only if:

$$
\ln \left(y_{i}-c_{i}\right)+\lambda_{i g}\left(E\left[w_{i} \mid D_{i}=0\right]-\frac{3}{2}+\widehat{\Delta}_{i}\right) \geq \ln y_{i}+\lambda_{i g}\left(E\left[w_{i} \mid D_{i}=0\right]-\frac{3}{2}\right)
$$

Rearranging this gives $\lambda_{i g} \widehat{\Delta}_{i} \geq \ln y_{i}-\ln \left(y_{i}-c_{i}\right)$.

Therefore, the thresholds for choosing $D_{i}=1$ by households with different wealth levels are:

$$
\begin{aligned}
& \text { (a) } \lambda_{i g} \widehat{\Delta}_{i} \geq c_{i} \text { if } y_{i} \geq 1+c_{i} \\
& \text { (b) } \lambda_{i g} \widehat{\Delta}_{i} \geq y_{i}-1-\ln \left(y_{i}-c_{i}\right) \text { if } 1<y_{i}<1+c_{i} \\
& \text { (c) } \lambda_{i g} \widehat{\Delta}_{i} \geq \ln y_{i}-\ln \left(y_{i}-c_{i}\right) \text { if } y_{i} \leq 1
\end{aligned}
$$

Noting that $c_{i}=c_{C}$ if $T_{i}=0$ and $c_{T}$ if $T_{i}=1$ with $c_{C} \geq c_{T}$ and the thresholds for $\lambda_{i g} \widehat{\Delta}_{i}$ are increasing in the cost of education, it is clear that households with $y_{i} \leq 1$ will face a lower threshold for choosing $D_{i}=1$ in the treatment group compared to that in the comparison group. For the other two possibilities, we need to account for the factor that a change in the cost of education might change the classification of the household. For example, households with wealth level $1<y_{i}<1+c_{C}$ would have either $1+c_{C}>y_{i} \geq 1+c_{T}$ or $1<y_{i}<1+c_{T}$. If they were chosen for the treatment group, in the first case, the corresponding threshold would change from $y_{i}-1-\ln \left(y_{i}-c_{C}\right)$ to $y_{i}-1-\ln \left(y_{i}-c_{T}\right)$, and in the second to $c_{T}$. It is easy to see that in the first case the threshold decreases if the household receives the treatment. In the second case, there is also a decrease since $y_{i}<c_{C}+1$ and therefore $y_{i}-1-\ln \left(y_{i}-c_{C}\right)>c_{C}>c_{T}$. Hence, for any wealth level $y$, households in the treatment group will face a lower threshold for weighted utility gain $\lambda_{i g} \widehat{\Delta}_{i}$ from choosing $D_{i}=1$ than households in the comparison group (we refer to this result as I).

We have that the reward from enrollment in secondary education for the offspring is:

$$
\widehat{\Delta}_{i}\left(\hat{a}_{i}\right)=E\left[u_{i} \mid D_{i}=1\right]-E\left[u_{i} \mid D_{i}=0\right]
$$


Taking the derivative of $\widehat{\Delta}_{i}$ with respect to perceived ability, we get:

$$
\begin{gathered}
\frac{\partial \widehat{\Delta}_{i}}{\partial \hat{a}_{i}}=\frac{\partial E\left[u_{i} \mid D_{i}=1\right]}{\partial \hat{a}_{i}}-\frac{\partial E\left[u_{i} \mid D_{i}=1\right]}{\partial \hat{a}_{i}}= \\
\frac{\partial E\left[u_{i} \mid D_{i}=1\right]}{\partial \hat{s}_{i_{\mid D_{i}=1}}} \frac{\partial \hat{s}_{i_{\mid D_{i}=1}}}{\partial \hat{a}_{i}}-\frac{\partial E\left[u_{i} \mid D_{i}=0\right]}{\partial \hat{s}_{i_{\mid D_{i}=0}}} \frac{\partial \hat{s}_{i_{\mid D_{i}=0}}}{\partial \hat{a}_{i}}
\end{gathered}
$$

We know that $\frac{\partial E\left[u_{i} \mid D_{i}=1\right]}{\partial \hat{s}_{i \mid D_{i}=1}}, \frac{\partial E\left[u_{i} \mid D_{i}=0\right]}{\partial \hat{s}_{i_{\mid D_{i}}=0}}>0$ and $\frac{\partial E\left[u_{i} \mid D_{i}=1\right]}{\partial \hat{s}_{i_{\mid D_{i}}=1}} \geq \frac{\partial E\left[u_{i} \mid D_{i}=0\right]}{\partial \hat{s}_{i_{\mid D_{i}}=0}}$. The derivatives will be identical if secondary school does not lead the offspring to choose a different sector in the labor market while the strict inequality will hold otherwise. Note from the results in Proposition 1 that an increase in skill will never lead the offspring to choose another sector with lower return to skill than the original one.

We also know that $\frac{\partial \hat{s}_{i \mid D_{i}=1}}{\partial \hat{a}_{i}}, \frac{\partial \hat{s}_{i \mid D_{i}=0}}{\partial \hat{a}_{i}}>0$ and due to the complementarity between education and ability in the skill technology, and since an investment in secondary education increases the education level of the offspring, $\frac{\partial \hat{s}_{i \mid D_{i}=1}}{\partial \hat{a}_{i}}>\frac{\partial \hat{s}_{i \mid D_{i}=0}}{\partial \hat{a}_{i}}$. Hence $\frac{\partial \widehat{\Delta}_{i}}{\partial \hat{a}_{i}}>0$ and by continuity there exists a threshold level of the estimate of child ability above which all households will invest in education which gives the result in (i).

(ii) All else equal, this threshold level of ability will be greater for households in the comparison group than the treatment group given the derivation in (i) above. This yields the result in (ii).

Proof of Proposition 3: (i) If all households are identical in wealth and if all households weigh boys' and girls' utility equally, all households will face the same ability threshold $a^{*}$. Scholarships lowering the cost of education from $c_{C}$ to $c_{T}$ will lead all households to lower this threshold for ability given Proposition 2. Therefore, the marginal children getting education in response to this scholarship will have lower ability. This gives the result in (i).

(ii) On the other hand, if there is heterogeneity in wealth and thus thresholds, it is possible that marginal secondary school students could have higher initial ability than inframarginal secondary school students. To see this, consider an extreme case in which there are two types of household with the same $\lambda_{i g}$ : rich with $y_{i}>1+c_{C}$ and poor with $y_{i}<1$. Suppose that $\lambda_{i g} \widehat{\Delta}_{i}=c_{C}$ for the rich households so that they send their children to secondary school whereas $\lambda_{i g} \widehat{\Delta}_{i}<\ln y_{i}-$ $\ln \left(y_{i}-c_{C}\right)$ for the poor households so that they do not send their children to school. For $y_{i}<1$, 
$\ln y_{i}-\ln \left(y_{i}-c_{C}\right)>c_{C}$, so we can further assume $\lambda_{i g} \widehat{\Delta}_{i}>c_{C}$, for the poor households. Then a scholarship of $\frac{y_{i}-\left(y_{i}-c_{C}\right) \exp \left(\lambda_{i g} \widehat{\Delta}_{i}\right)}{\exp \left(\lambda_{i g} \widehat{\Delta}_{i}\right)}$ which ensures that $\lambda_{i g} \widehat{\Delta}_{i}=\ln y_{i}-\ln \left(y_{i}-c_{T}\right)$ for the poor households will induce them to send their children to school while leaving the decisions of the rich households unchanged. These marginal children will have a higher ability than the inframarginal children since $\widehat{\Delta}_{i}$ faced by the poor households is greater than that faced by the rich households and $\widehat{\Delta}_{i}$ is increasing in ability as shown in Proposition 2 . This proves the result in (ii).

(iii) Similarly, if households are heterogenous in their level of altruism for the child's welfare, with some caring more about their children, for example, because of preferences for boys, then the marginal children induced to secondary education may have higher ability than inframarginal children.

To see this, assume there are two types of households, household $h$ with higher level of parental altruism for their child's welfare $\lambda_{h}, l$ with lower level $\lambda_{l}$ and a child with higher ability, all other parameters are equal. Neither faces credit constraint, i.e., $y_{h}=y_{l}>1+c_{C}$. As $\lambda_{h}>\lambda_{l}$, it can be that $\lambda_{h} \widehat{\Delta}_{l}>\lambda_{h} \widehat{\Delta}_{h} \geq c_{C}>\lambda_{l} \widehat{\Delta}_{l}$, in other words household $h$ send their children to secondary education, while household $l$ whose child has higher ability does not. A scholarship such that $\lambda_{l} \widehat{\Delta}_{l}>c_{T}$ will mean that marginal children induced to enroll in secondary education due to the scholarship will have higher ability than the marginal children. This proves (iii). This also implies that if there is heterogeneity in gender bias, then the marginal girls induced into school by free secondary education may have higher ability than inframarginal girls.

(iv) Finally, if there is heterogeneity in ability perception, it is also possible that marginal students have higher initial ability than inframarginal ones. Consider again two households where one perceives the offspring's ability following function $b_{l}(a)$ and the other following a function $b_{h}(a)$, where $b_{h}(a)>b_{l}(a)$ over the entire support of $a$, we also know that $a_{l}>a_{h}$. The income levels are such that $y_{h}=y_{l}>1+c_{C}$ and all other parameters are the same. Under this scenario, it could be the case that $\lambda_{h} \widehat{\Delta}_{h} \geq c_{C}>\lambda_{l} \widehat{\Delta}_{l}$. Once again, scholarship that guarantees $\lambda_{l} \widehat{\Delta}_{l}>c_{T}$ would lead the pessimistic household (l) to invest in secondary education and the marginal offspring would have higher ability than the inframarginal. This proves (iv).

Proof of Proposition 4: (i) Since $\frac{\partial s}{\partial h}>0$ and wages increase with skill in all sectors, marginal students are guaranteed to improve their utility either through a transfer or through changes in 
wages with a scholarship. Inframarginal students, however, will not change their education level with the scholarship and therefore will remain with the same skill level and wages. So, for them, the scholarship represents only a transfer. This proves (i).

(ii) Suppose initially a population where no household chooses $D=1$ and all offspring choose the private wage-employment sector regardless of the scholarship. A scholarship induces $D=1$ for the entire population and some manage to graduate from secondary school, although no one completes tertiary education even with the scholarship. In this case, a scholarship would increase the skill distribution of the population and their wages in the private competitive sector, consequentially increasing average earnings.

Alternatively, consider that the entire population completes secondary education regardless of the scholarship (all inframarginal students). In this case, a scholarship would have no impact on average earnings.

Finally, suppose that the population includes one high skilled worker with skill $s 1$ such that $s 1_{D_{i}=0}>\frac{f_{p}}{A_{p}-A_{h}}$ and one low skilled worker with skill $s 2$, such that $s 2_{D_{i}=0}<\frac{f_{p}}{A_{p}-A_{h}}$, in the absence of the scholarship, no one completes secondary education and worker 2 chooses self-employment. The average earnings without the scholarship is simply $0.5 \times\left[w_{p}(s 1)+w_{h}(s 2)\right]$. Now consider that with the scholarship, both offspring complete secondary education and the high skilled worker completes tertiary education, becoming eligible for the public sector. The skill levels increase to $s 1_{D_{i}=1}$ and $s 2_{D_{i}=1}$ where $s 1_{D_{i}=0}+\frac{1-\phi}{A_{p}}>s 1_{D_{i}=1}>s 1_{D_{i}=0}$ and $s 2_{D_{i}=1}=\frac{f_{p}}{A_{p}-A_{h}}>s 2_{D_{i}=0}$. Note that since $w_{p}=A_{p} s+e-f_{p}$ and $w_{g}=A_{p} s+\phi-f_{p}$ we will have $w_{g}\left(s 1_{D_{i}=1}\right)<w_{p}\left(s 1_{D_{i}=0}\right)$. Therefore, the high skilled worker will experience an increase in utility but a decrease in wage with the transfer. Additionally, the low skilled worker will be able to join the competitive private sector with the scholarship but earning a lower wage than $w_{p}(s 1)$ since $s 2_{D_{i}=1}<s 1_{D_{i}=0}$. Both changes lead the average earnings in the wage sectors to decrease. It can also lead to a decrease in overall average earnings if $w_{p}\left(s 1_{D_{i}=0}\right)-w_{g}\left(s 1_{D_{i}=1}\right)>w_{p}\left(s 2_{D_{i}=1}\right)-w_{h}\left(s 2_{D_{i}=0}\right)$. These three examples prove (ii).

Proof of Proposition 5: (i) The argument for the proof is as follows. At $t=2$, secondary graduates who do well enough in school continue to tertiary education while the rest joins the labor market. Those who are in tertiary education at $\mathrm{t}=2$ might earn more at $\mathrm{t}=3$ than those that were already in the labor market. However, at $\mathrm{t}=2$, those in tertiary education certainly do not have any earnings (foregone due to education), therefore earning less than those in the labor market. With a 
scholarship for secondary education, there will be marginal students who will go to secondary education, of which some will eventually end up progressing to tertiary education, only joining the labor market at $\mathrm{t}=3$. Hence the difference of earnings between the treatment group and the comparison group will be larger at $\mathrm{t}=3$. This gives (i).

(ii) At $t=3$, high ability agents who secure public sector jobs will reduce their effort and take part of their rents as increased utility. In the treatment group, a share of the marginal tertiary graduates will be able to get premium jobs and simultaneously increase their utility beyond an increase in wage. Therefore, comparing the difference in earnings conditional on employment between the treatment and control group will underestimate the welfare effect. This gives (ii).

Proof of Proposition 6: We know that production in the public sector is given by $Y_{g}=A_{g} s+$ $e-f_{g}$. Let $E\left[u_{g}^{*}\right]$ denote the maximum expected utility of public sector workers. Solving the utility maximization problem as before gives $E\left[u_{g}^{*}\right]=A_{p} s+\phi-f_{p}-1+\gamma_{g} h$, which is the case for $e=0$, which leads to $E\left[Y_{g}^{*}\right]=A_{g} s-f_{g}$. Consider a scenario where a single offspring received the scholarship, experiencing an increase in skill level from $S_{D_{i}=0}$ to $S_{D_{i}=1}$, where $\frac{f_{p}}{A_{p}-A_{h}}<s_{D_{i}=0}<$ $S_{D_{i}=1}$. The expected variation in net economic output caused by this cross-sectoral switch is:

$$
\Delta_{\mathrm{i}}^{\text {out }}=A_{g} S_{D_{i}=1}-f_{g}-A_{p} S_{D_{i}=0}-1+f_{p}-c_{c}
$$

We use $c_{c}$ to capture the cost to society of the extra individual in secondary education. If $A_{g}$ is sufficiently greater than $A_{p}$ and/or $S_{D_{i}=1}$ sufficiently greater than $S_{D_{i}=0}$ such that $A_{g} S_{D_{i}=1}-$ $A_{p} S_{D_{i}=0}>f_{g}+1-f_{p}+c_{c}$ then there will be an expected production gain from the cross-sectoral switch. In this case, if the household decides to invest on education, we can also expect a positive gain in terms of net economic output. This scenario could also motivate a scholarship program to capture the incentives of production gain, which are not reflected in the institutionalized wage. In the opposite case, where $A_{g} s_{D_{i}=1}-A_{p} S_{D_{i}=0}<f_{g}+1-f_{p}+c_{c}$, the household would have private gains from having the offspring migrating from the private wage-employment sector to public, all else equal, while the net economic output would decrease. In this scenario, it could even make sense to tax education to reduce entry in the public sector.

We can easily build an analogous case where the migration happens from self-employment to the public sector, in this case the left-hand side would be $A_{g} S_{D_{i}=1}-A_{h} S_{D_{i}=0}$ and the right-hand side would be $f_{g}+1$. Once again, if $A_{g} s_{D_{i}=1}-A_{h} s_{D_{i}=0}>f_{g}+1+c_{c}$, the scholarship would lead to 
net economic production gains, and if $A_{g} S_{D_{i}=1}-A_{h} S_{D_{i}=0}<f_{g}+1+c_{C}$ the scholarship will lead to losses.

Consider now that there are 2 workers in the economy, one with skill $\frac{f_{p}}{A_{p}-A_{h}}<s_{1}$ and $h=1$ in the absence of the scholarship and skill $s^{\prime}{ }_{1}=s(3, \underline{a})>s_{1}$ and $h=3$ with the scholarship. Worker 2 is an inframarginal secondary school student and has skill that follows $s_{2}=s_{2}^{\prime}>s(3, \underline{a})$ and $h=3$ regardless of the scholarship. Worker 1 chooses the private sector in the absence of the scholarship and the public sector in the counterfactual scenario. Worker 2 always chooses the public sector. We assume that there is only one position in the public sector. In the absence of the scholarship, economic production is given by:

$$
\left.Y_{t}\right|_{D_{i=0}}=A_{g} s_{2}-f_{g}+A_{p} s_{1}+1-f_{p}
$$

Where we assume $\eta=0$. In the scenario with the scholarship there are two possibilities of outcomes since both workers prefer the public sector. In the first case, worker 2 is selected to the public sector and the total economic production is:

$$
\left.Y_{t}\right|_{D_{i=1}}=A_{g} s_{2}-f_{g}+A_{p} s_{1}^{\prime}+1-f_{p}>\left.Y_{t}\right|_{D_{i=0}}
$$

We abstract away the education cost in this example to focus on the impact of the lottery selection, which does not change our conclusions. In the second case, if worker 1 is selected to work in the public sector, the total economic production is:

$$
\left.Y_{t}\right|_{D_{i=1}}=A_{g} s^{\prime}{ }_{1}-f_{g}+A_{p} s_{2}+1-f_{p}>\left.Y_{t}\right|_{D_{i=0}}
$$

In the latter case, there is certain loss of production in the public sector and certain gain in productivity in the competitive private sector. So, it could be the case that:

$$
A_{g} s_{2}+A_{p} s_{1}>A_{g} s^{\prime}{ }_{1}+A_{p} s_{2}
$$

This could be the case even if we have:

$$
A_{g} s_{1}^{\prime}-A_{p} s_{1}>f_{g}+1-f_{p}
$$

Implying that $\left.Y_{t}\right|_{D_{i=0}}>\left.Y_{t}\right|_{D_{i=1}}$ despite the individual improvement in productivity for the worker that migrated to the public sector. A simple example is enough to prove this such as: $A_{g}=2, A_{p}=$ $1, s_{1}=3, s^{\prime}{ }_{1}=4, s_{2}=6, f_{p}=0.5, f_{g}=\phi=1.5$. 


\section{Appendix B: Comparison between OLS, IV and DML estimate}

This section computes instrumental variable (IV) estimates of the effect of an extra year of education, compares them to the OLS, and tests whether the IV estimates can be recovered through recent new non-experimental machine learning techniques.

For the IV, we assume that net non-educational effects and effects on infra-marginal applicants can be neglected, and estimate:

$$
y_{i}=a_{i}+\beta S_{i}+\varepsilon_{i}
$$

where $S_{\mathrm{i}}$ is the number of years of education for individual $i$ and $y_{i}$ is the outcome of interest. We use winning the scholarship as an instrument for years of education. This estimates the local treatment effect of education on compliers. It is therefore of interest to know how compliers compare to alwaystakers in background characteristics. Tables B1 and B2 show the difference in background characteristics between treatment and control groups, among those who completed senior high school. Interestingly, we find no difference in the junior high school exit exam score, suggesting that compliers and always takers were performing equally, and confirming the premise that ability to pay fees is the key barrier to enrollment for compliers.

Before using the scholarship as an instrument, however, we need to discuss its validity. We now argue that non-educational channels of scholarship effects are likely to be small, and that while exclusion restrictions are probably not literally satisfied, instrumental variable estimates of the effect of education based on using random assignment of scholarship receipt are likely to be reasonable approximations of the causal effect of education.

A first concern with using the scholarship assignment as an instrument is that the scholarship represented a wealth transfer to infra-marginal families who would have paid for senior high school in the absence of the scholarship. But it also reduced earnings by children induced to attend senior high school by the scholarship during the period of senior high school enrollment. We estimate that these effects roughly offset each other in our context.

To see this, note that for those who would have paid for senior high school themselves in the absence of a scholarship ("always takers"), the scholarship is akin to $\mathrm{GHX}^{33} 2,328$ cash transfer to the family

33 All numbers reported in 2017 GHX. 
of the student. As they make up about $50 \%$ of the scholarship winners (based on the control group, $58 \%$ would have enrolled anyway and 54.3\% would have completed all four years absent the scholarship), this makes the wealth transfer GHX 1,164 on average for the treatment group as a whole.

In contrast, those who go to secondary school due to the scholarship ("compliers"), forego labor market earnings while in school and incur extra expenditure on school materials. Based on our estimates of foregone earnings while in senior high school and extra schooling expenditure over the lifetime of the scholarship (Table B3), we calculate a total cost in 2017 GHX of 1,294. Reductions in unpaid household labor by students induced to attend senior high school by the scholarship presumably increase this amount, but we do not have the data to put a GHX value on this. Overall, the positive and negative effects on household income are comparable in size and seem to offset each other (though obviously the gains and losses are experienced by different households - the always takers for the reduction in school fees and the compliers for the reduction in earnings-- and at different time periods). We also find no impact of the scholarship on the educational attainment of siblings, consistent with the hypothesis that wealth effects on household investments due to the scholarship are small.

There could also be psychological effects of winning a lottery that are different from the effects of a scholarship per se. We collected data to check for this channel. As shown in Table B3, we do not see large effects on risk or time preferences. We also see no evidence that the scholarship affected confidence levels (see Figure B1).

Overall the non-education impacts of the scholarship appear modest, suggesting that using the scholarship as an instrument for years of education may provide a reasonable approximation of the true effect.

One other potential channel through which the exclusion restriction could be violated is if the scholarships affected later outcomes such as tertiary education, fertility, or labor market outcomes, not only by increasing the chance that marginal students ("compliers") would attend secondary school, but also by affecting effort in school, or other determinants of academic success, by infra-marginal students ("always takers"). Hypothetically, scholarships could have increased effort for these inframarginal students by making them less likely to have been temporarily kicked out of school for failure to pay school fees, or to have experienced stress around this possibility, or by making them more certain that they would be able to afford to complete school. Of course, it is also possible that 
scholarships reduced effort among these students because they no longer had to fear withdrawal of financial support if they did not maintain high academic performance.

Table B4 reports OLS and IV estimates of the returns to education for our key outcomes: test scores, fertility, health behavior, type of employment, earnings. The OLS estimates are based on the control group only. The IV estimates use the full sample and instrument years of education with the randomized scholarship treatment assignment. We present the OLS results without any controls, the OLS results controlling for BECE score, and the IV. The OLS estimates are at times higher (educational attainment, learning) and at times lower (earnings, preventative health behavior) than the IV estimates of the returns.

We perform a Lalonde (AER 1986)-type exercise to test whether we can recover the IV estimates from the control group with recent Machine Learning (ML) techniques. Specifically, we ask: can causal effects be recovered by controlling for the very rich set of control variables (over 1,000) that we collected at baseline?

To select from among the many available observables that can be used as control, we apply the Double Machine Learning method proposed in Chernozhukov et al. (2018). In a nutshell, the estimate works by using a random forest to flexibly partial out the effect of the baseline control variables from both the outcome variables and the education variable, to recover the causal effect of education, under the assumption that assignment is as good as random, once these sets of variables is controlled for.

The results suggest that, despite the wealth of control variables available, the machine learning estimates are generally quite close to OLS estimates, suggesting that the observed covariates do very little to account for the selection bias into education. For most outcomes, the weighted DoubleML estimate is closer to the IV estimate than the raw OLS estimate, but in most cases less than half of the gap is closed. For example, the OLS estimates of the effect of education on test scores (0.25 for females and 0.16 for males) is larger than the IV estimate ( 0.15 for females and 0.09 for males), perhaps reflecting a standard ability bias. The DoubleML estimate is 0.22 for females and 0.16 for males-a little lower than the OLS, but not by much.

One possible reason why the IV and the DoubleML estimates are different even if both are causal estimates is that the OLS and IV estimate effects for different subgroups: the IV estimates the local average treatment effect on compliers (those who can only attend secondary education if they get a 
scholarship) while the OLS estimates effects for always takers. To account for this, we developed a weighted DoubleML estimate, which uses DoubleML to estimate the average treatment effect for those who share the observable characteristics of the compliers. In practice, we first use a random forest to obtain an estimate of conditional average treatment effect (CATE) as a function of the baseline variable. This allows us to predict, as a function of the observable variable, the probability that each person is a complier. These estimates are then used to weight the observation in the second stage to obtain the estimates for a sample that is observationally equivalent to the complier group. A finding that the "weighted DoubleML" estimate is close to the IV estimate would imply that any difference between the regular DoubleML and the IV are due to the fact that the IV recovers a different estimate, suggesting that the (unweighted) DoubleML may be a good estimate of the ATE on education. As it turns out, the weighted DoubleML does get closer to the IV for most outcomes, though not always.

Overall, these results suggest that despite the challenges and costs associated with longitudinal datasets, identifying other sources of experimental or quasi-experimental variation in educational attainment coupled with long-run follow up-data is going to be key to accurately measure the effect of secondary education. On a side note, it also suggests that continuing to stress-test the DoubleML approach by comparing experimental and non-experimental variation would be very valuable. 
Figure B1: Effects of Scholarship on accuracy of beliefs about relative performance

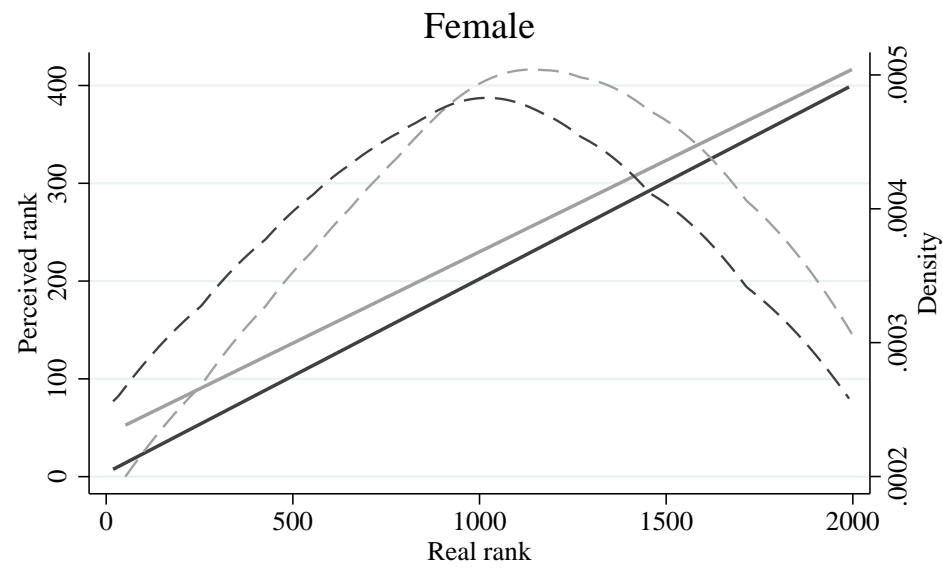

\begin{tabular}{|llll|}
\hline Linear fits: & & Control & Treatment \\
Densities: & $-\ldots--$ Control & $-\ldots--$ & Treatment \\
\hline
\end{tabular}

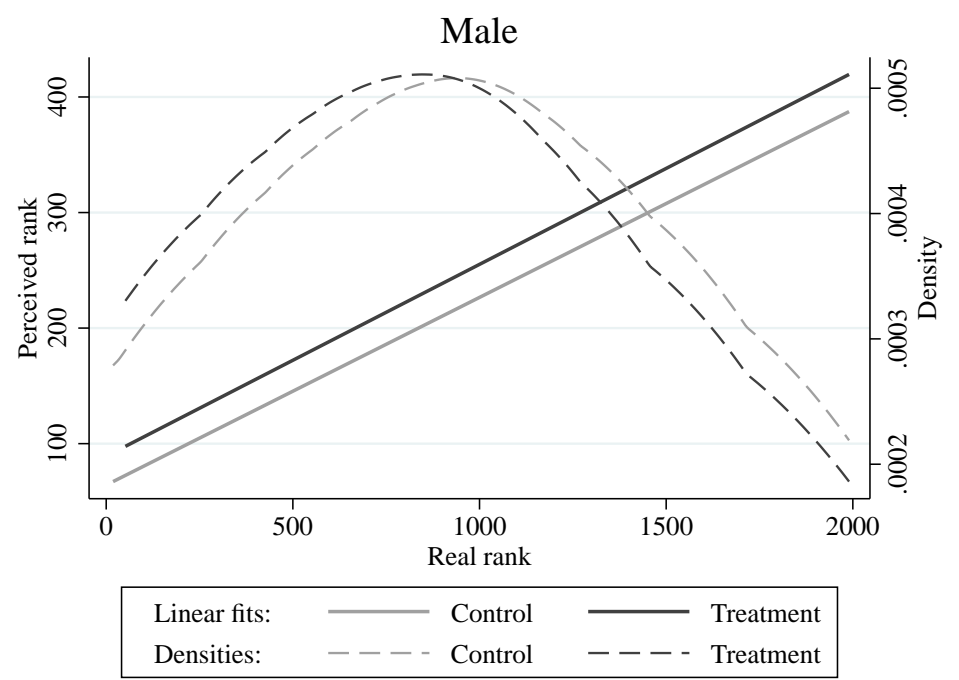

Notes: "Real rank" is the rank on the math and reading comprehension test administered during the 2013 follow-up survey. "Perceived rank" is the rank that the respondent reported when asked, immediately after the test: "We are administering this survey to around 2,000 youths your age (1,000 boys and 1,000 girls). All of those we are interviewing completed JHS around the same time as you, in 2007 or 2008. Overall, how do you think your performance on the games will compare to that of the others? Try to guess your rank between 1 and 2,000, with 1 being the person with the highest/top score and 2,000 being the person with the lowest score." The density (right-hand y-axis) shows the distribution of the real rank, by treatment group. The linear fits show the relationship between the real rank (x-axis) and the perceived rank (left-hand y-axis), by treatment group. 
Table B1: Comparing Compliers and Always-Takers: Education

\begin{tabular}{|c|c|c|c|c|c|c|c|c|c|c|c|c|}
\hline & $\begin{array}{c}(1) \\
\text { Completed } \\
\text { BECE } \\
\text { in } 2007 \\
(2008) \\
\end{array}$ & $\begin{array}{c}\text { BECE } \\
\text { exam } \\
\text { performance } \\
(2008) \\
\end{array}$ & $\begin{array}{c}(3) \\
\text { BECE } \\
\text { performance } \\
\text { data } \\
\text { missing } \\
(2008) \\
\end{array}$ & $\begin{array}{l}\text { Admitted } \\
\text { to } \\
\text { academic } \\
\text { major } \\
\end{array}$ & $\begin{array}{c}(5) \\
\text { Years of } \\
\text { education } \\
\text { of HH } \\
\text { head } \\
(2008) \\
\end{array}$ & $\begin{array}{c}(6) \\
\text { Highest } \\
\text { education } \\
\text { of HH head: } \\
\text { tertiary } \\
(2008) \\
\end{array}$ & $\begin{array}{c}(7) \\
\text { Perceived } \\
\text { returns } \\
\text { to SHS } \\
(\%) \\
(2008) \\
\end{array}$ & $\begin{array}{c}(8) \\
\text { Perceived } \\
\text { returns } \\
\text { to SHS } \\
>100 \% \\
(2008) \\
\end{array}$ & $\begin{array}{c}\text { Reading } \\
\text { test } \\
\text { score } \\
(2013) \\
\end{array}$ & $\begin{array}{l}\text { Math } \\
\text { test } \\
\text { score } \\
(2013) \\
\end{array}$ & $\begin{array}{c}(11) \\
\text { Total } \\
\text { cognitive } \\
\text { score } \\
(2013) \\
\end{array}$ & $\begin{array}{c}(12) \\
\text { Ever } \\
\text { enrolled } \\
\text { in } \\
\text { tertiary } \\
(2019) \\
\end{array}$ \\
\hline \multicolumn{13}{|l|}{ Panel A: All } \\
\hline Treatment & $\begin{array}{c}0.035 \\
(0.018)\end{array}$ & $\begin{array}{l}-0.002 \\
(0.005)\end{array}$ & $\begin{array}{c}0.014 \\
(0.015)\end{array}$ & $\begin{array}{c}0.022 \\
(0.029)\end{array}$ & $\begin{array}{l}-0.456 \\
(0.316)\end{array}$ & $\begin{array}{l}-0.021 \\
(0.013)\end{array}$ & $\begin{array}{c}25.959 \\
(35.790)\end{array}$ & $\begin{array}{c}0.017 \\
(0.031)\end{array}$ & $\begin{array}{l}-0.018 \\
(0.042)\end{array}$ & $\begin{array}{c}0.024 \\
(0.052)\end{array}$ & $\begin{array}{c}0.006 \\
(0.047)\end{array}$ & $\begin{array}{l}-0.029 \\
(0.026)\end{array}$ \\
\hline P-value & 0.047 & 0.603 & 0.356 & 0.462 & 0.149 & 0.113 & 0.468 & 0.592 & 0.669 & 0.642 & 0.892 & 0.270 \\
\hline Comparison mean & 0.080 & 0.632 & 0.064 & 0.410 & 6.127 & 0.066 & 281.445 & 0.468 & 0.391 & 0.302 & 0.403 & 0.289 \\
\hline $\mathrm{N}$ & 1193 & 1110 & 1193 & 1166 & 1188 & 1188 & 1036 & 1036 & 1164 & 1164 & 1164 & 1152 \\
\hline \multicolumn{13}{|l|}{ Panel B: Female } \\
\hline Treatment & $\begin{array}{c}0.079 \\
(0.037)\end{array}$ & $\begin{array}{l}-0.009 \\
(0.007)\end{array}$ & $\begin{array}{c}0.004 \\
(0.022)\end{array}$ & $\begin{array}{l}-0.014 \\
(0.044)\end{array}$ & $\begin{array}{l}-0.713 \\
(0.471)\end{array}$ & $\begin{array}{l}-0.036 \\
(0.020)\end{array}$ & $\begin{array}{c}38.254 \\
(52.827)\end{array}$ & $\begin{array}{c}0.007 \\
(0.048)\end{array}$ & $\begin{array}{l}-0.059 \\
(0.065)\end{array}$ & $\begin{array}{c}0.071 \\
(0.081)\end{array}$ & $\begin{array}{c}0.016 \\
(0.074)\end{array}$ & $\begin{array}{c}0.024 \\
(0.040)\end{array}$ \\
\hline $\mathrm{P}$-value & 0.033 & 0.175 & 0.843 & 0.752 & 0.130 & 0.066 & 0.469 & 0.878 & 0.367 & 0.381 & 0.832 & 0.552 \\
\hline Comparison mean & 0.180 & 0.631 & 0.065 & 0.450 & 6.377 & 0.079 & 293.682 & 0.490 & 0.427 & 0.182 & 0.344 & 0.276 \\
\hline $\mathrm{N}$ & 530 & 495 & 530 & 514 & 529 & 529 & 450 & 450 & 517 & 517 & 517 & 510 \\
\hline \multicolumn{13}{|l|}{ Panel C: Male } \\
\hline Treatment & $\begin{array}{c}0.000 \\
(.)\end{array}$ & $\begin{array}{c}0.003 \\
(0.006)\end{array}$ & $\begin{array}{c}0.020 \\
(0.020)\end{array}$ & $\begin{array}{c}0.047 \\
(0.039)\end{array}$ & $\begin{array}{l}-0.200 \\
(0.426)\end{array}$ & $\begin{array}{l}-0.009 \\
(0.017)\end{array}$ & $\begin{array}{c}21.456 \\
(48.026)\end{array}$ & $\begin{array}{c}0.026 \\
(0.042)\end{array}$ & $\begin{array}{c}0.016 \\
(0.056)\end{array}$ & $\begin{array}{l}-0.010 \\
(0.068)\end{array}$ & $\begin{array}{c}0.002 \\
(0.060)\end{array}$ & $\begin{array}{l}-0.066 \\
(0.035)\end{array}$ \\
\hline P-value & . & 0.647 & 0.329 & 0.226 & 0.639 & 0.619 & 0.655 & 0.529 & 0.770 & 0.882 & 0.973 & 0.061 \\
\hline Comparison mean & 0.000 & 0.633 & 0.063 & 0.379 & 5.926 & 0.055 & 271.895 & 0.451 & 0.363 & 0.396 & 0.450 & 0.299 \\
\hline $\mathrm{N}$ & 663 & 615 & 663 & 652 & 659 & 659 & 586 & 586 & 647 & 647 & 647 & 642 \\
\hline P-val male $=$ fem & 0.032 & 0.194 & 0.616 & 0.284 & 0.372 & 0.294 & 0.862 & 0.760 & 0.396 & 0.454 & 0.887 & 0.106 \\
\hline
\end{tabular}

Notes: See Table 1 notes. Controls include region dummies. Compliers and always-takers are determined by those who had completed SHS as of 2020 (or any year prior). 
Table B2: Comparing Compliers and Always-Takers: Descriptive Characteristics

\begin{tabular}{|c|c|c|c|c|c|c|c|c|c|c|c|c|}
\hline & $\begin{array}{l}\text { Age in } \\
2008\end{array}$ & Female & $\begin{array}{c}(3) \\
\text { No male } \\
\text { head in } \\
\text { household } \\
(2008)\end{array}$ & $\begin{array}{l}\text { Number } \\
\text { of HH } \\
\text { members } \\
(2008)\end{array}$ & $\begin{array}{c}\text { Ever } \\
\text { had sex } \\
(2008)\end{array}$ & $\begin{array}{c}\text { Yearly } \\
\text { HH } \\
\text { expenditure } \\
\text { (2008) }\end{array}$ & $\begin{array}{c}(7) \\
\text { House walls } \\
\text { made of: } \\
\text { mud, wood, } \\
\text { plastic, } \\
\text { iron (2008) }\end{array}$ & $\begin{array}{c}(8) \\
\text { Number } \\
\text { of rooms } \\
\text { in house } \\
(2008)\end{array}$ & $\begin{array}{c}\text { Toilet } \\
\text { in house } \\
(2008)\end{array}$ & $\begin{array}{c}\text { (10) } \\
\text { HH member } \\
\text { went to } \\
\text { bed hungry } \\
\text { in last mo. } \\
(2008)\end{array}$ & $\begin{array}{c}\text { (11) } \\
\text { Meal w/o } \\
\text { meat/fish } \\
\text { because no } \\
\text { money in last } \\
\text { mo. (2008) }\end{array}$ & $\begin{array}{c}(12) \\
\text { Self-reported } \\
\text { financial } \\
\text { situation, } 1-5 \\
(5=\text { very poor }) \\
2008\end{array}$ \\
\hline \multicolumn{13}{|l|}{ Panel A: All } \\
\hline Treatment & $\begin{array}{c}0.154 \\
(0.087)\end{array}$ & $\begin{array}{l}-0.001 \\
(0.029)\end{array}$ & $\begin{array}{c}0.027 \\
(0.029)\end{array}$ & $\begin{array}{l}-0.103 \\
(0.139)\end{array}$ & $\begin{array}{l}-0.004 \\
(0.025)\end{array}$ & $\begin{array}{c}127.902 \\
(129.240)\end{array}$ & $\begin{array}{l}-0.012 \\
(0.028)\end{array}$ & $\begin{array}{c}0.055 \\
(0.144)\end{array}$ & $\begin{array}{l}-0.027 \\
(0.029)\end{array}$ & $\begin{array}{c}0.055 \\
(0.019)\end{array}$ & $\begin{array}{c}0.014 \\
(0.023)\end{array}$ & $\begin{array}{c}0.071 \\
(0.040)\end{array}$ \\
\hline P-value & 0.078 & 0.978 & 0.350 & 0.461 & 0.886 & 0.323 & 0.673 & 0.704 & 0.366 & 0.005 & 0.539 & 0.077 \\
\hline Comparison mean & 17.048 & 0.445 & 0.410 & 5.715 & 0.239 & 2603.802 & 0.438 & 3.016 & 0.413 & 0.095 & 0.182 & 3.853 \\
\hline $\mathrm{N}$ & 1191 & 1193 & 1192 & 1192 & 1192 & 1190 & 1190 & 1169 & 1120 & 1189 & 1182 & 1185 \\
\hline \multicolumn{13}{|l|}{ Panel B: Female } \\
\hline Treatment & $\begin{array}{c}0.299 \\
(0.128)\end{array}$ & $\begin{array}{c}0.000 \\
(.)\end{array}$ & $\begin{array}{l}-0.006 \\
(0.044)\end{array}$ & $\begin{array}{l}-0.055 \\
(0.196)\end{array}$ & $\begin{array}{c}0.002 \\
(0.042)\end{array}$ & $\begin{array}{c}159.277 \\
(185.400)\end{array}$ & $\begin{array}{c}0.003 \\
(0.042)\end{array}$ & $\begin{array}{c}0.106 \\
(0.229)\end{array}$ & $\begin{array}{l}-0.010 \\
(0.044)\end{array}$ & $\begin{array}{c}0.021 \\
(0.027)\end{array}$ & $\begin{array}{c}0.036 \\
(0.033)\end{array}$ & $\begin{array}{c}0.060 \\
(0.059)\end{array}$ \\
\hline $\mathrm{P}$-value & 0.019 & . & 0.896 & 0.779 & 0.958 & 0.391 & 0.937 & 0.644 & 0.813 & 0.436 & 0.274 & 0.315 \\
\hline Comparison mean & 16.852 & 1.000 & 0.435 & 5.663 & 0.340 & 2565.644 & 0.392 & 3.043 & 0.413 & 0.098 & 0.142 & 3.797 \\
\hline $\mathrm{N}$ & 528 & 530 & 530 & 530 & 529 & 528 & 529 & 522 & 502 & 530 & 525 & 529 \\
\hline \multicolumn{13}{|l|}{ Panel C: Male } \\
\hline Treatment & $\begin{array}{c}0.031 \\
(0.118)\end{array}$ & $\begin{array}{c}0.000 \\
(.)\end{array}$ & $\begin{array}{c}0.053 \\
(0.039)\end{array}$ & $\begin{array}{l}-0.122 \\
(0.197)\end{array}$ & $\begin{array}{l}-0.012 \\
(0.028)\end{array}$ & $\begin{array}{c}101.079 \\
(181.954)\end{array}$ & $\begin{array}{l}-0.027 \\
(0.039)\end{array}$ & $\begin{array}{c}0.006 \\
(0.183)\end{array}$ & $\begin{array}{l}-0.042 \\
(0.040)\end{array}$ & $\begin{array}{c}0.080 \\
(0.027)\end{array}$ & $\begin{array}{l}-0.003 \\
(0.032)\end{array}$ & $\begin{array}{c}0.080 \\
(0.054)\end{array}$ \\
\hline P-value & 0.795 & . & 0.173 & 0.536 & 0.665 & 0.579 & 0.490 & 0.976 & 0.294 & 0.003 & 0.926 & 0.139 \\
\hline Comparison mean & 17.205 & 0.000 & 0.391 & 5.756 & 0.157 & 2634.349 & 0.475 & 2.995 & 0.414 & 0.092 & 0.213 & 3.899 \\
\hline $\mathrm{N}$ & 663 & 663 & 662 & 662 & 663 & 662 & 661 & 647 & 618 & 659 & 657 & 656 \\
\hline $\mathrm{P}$-val male $=\mathrm{fem}$ & 0.114 & . & 0.306 & 0.865 & 0.718 & 0.805 & 0.567 & 0.711 & 0.568 & 0.137 & 0.399 & 0.799 \\
\hline
\end{tabular}

Notes: See Table 1 notes. Controls include region dummies. Compliers and always-takers are determined by those who had completed SHS as of 2020 (or any year prior). 
Table B3: Impact of Scholarship on Foregone earnings, Preferences

\begin{tabular}{|c|c|c|c|c|c|c|c|}
\hline & $(1)$ & $(2)$ & $(3)$ & (4) & $(5)$ & (6) & (7) \\
\hline & $\begin{array}{c}\text { Avg. mo. } \\
\text { earnings } \\
\text { btw. } \\
\text { Jan } 2009 \\
\text { and } \\
\text { July } 2012 \\
(2013)\end{array}$ & $\begin{array}{l}\text { Trust } \\
\text { in } \\
\text { general } \\
(2013)\end{array}$ & $\begin{array}{l}\text { Amt. willing } \\
\text { to invest in } \\
\text { high-payoff } \\
\text { but risky } \\
\text { business } \\
(2013)\end{array}$ & $\begin{array}{l}\text { Amt. needed } \\
\text { in two } \\
\text { days to } \\
\text { forgo } 40 \\
\text { GHS today } \\
(2013)\end{array}$ & $\begin{array}{c}\text { Time } \\
\text { consistent } \\
(2013)\end{array}$ & $\begin{array}{c}\text { Present } \\
\text { bias } \\
(2013)\end{array}$ & $\begin{array}{c}\text { Extremely } \\
\text { impatient } \\
\text { in both } \\
\text { present } \\
\text { and future } \\
(2013)\end{array}$ \\
\hline \multicolumn{8}{|l|}{ Panel A: All } \\
\hline Treatment & $\begin{array}{l}-7.581 \\
(1.162)\end{array}$ & $\begin{array}{c}0.083 \\
(0.035)\end{array}$ & $\begin{array}{c}1.011 \\
(1.365)\end{array}$ & $\begin{array}{l}-0.993 \\
(5.917)\end{array}$ & $\begin{array}{c}0.014 \\
(0.024)\end{array}$ & $\begin{array}{c}0.001 \\
(0.021)\end{array}$ & $\begin{array}{c}-0.002 \\
(0.013)\end{array}$ \\
\hline $\mathrm{P}$-value & 0.000 & 0.018 & 0.459 & 0.867 & 0.541 & 0.964 & 0.857 \\
\hline Comparison mean & 12.249 & 0.000 & 51.077 & 100.783 & 0.409 & 0.258 & 0.087 \\
\hline $\mathrm{N}$ & 1939 & 1981 & 1981 & 1981 & 1981 & 1981 & 1984 \\
\hline \multicolumn{8}{|l|}{ Panel B: Female } \\
\hline Treatment & $\begin{array}{l}-5.564 \\
(1.214)\end{array}$ & $\begin{array}{c}0.150 \\
(0.048)\end{array}$ & $\begin{array}{c}0.374 \\
(1.970)\end{array}$ & $\begin{array}{l}-2.128 \\
(8.110)\end{array}$ & $\begin{array}{c}0.009 \\
(0.033)\end{array}$ & $\begin{array}{c}0.003 \\
(0.030)\end{array}$ & $\begin{array}{l}-0.008 \\
(0.018)\end{array}$ \\
\hline P-value & 0.000 & 0.002 & 0.850 & 0.793 & 0.787 & 0.912 & 0.646 \\
\hline Comparison mean & 8.996 & -0.044 & 51.136 & 99.727 & 0.400 & 0.270 & 0.085 \\
\hline $\mathrm{N}$ & 978 & 1001 & 1001 & 1001 & 1001 & 1001 & 1002 \\
\hline \multicolumn{8}{|l|}{ Panel C: Male } \\
\hline Treatment & $\begin{array}{l}-9.796 \\
(1.982)\end{array}$ & $\begin{array}{c}0.012 \\
(0.050)\end{array}$ & $\begin{array}{c}1.838 \\
(1.889)\end{array}$ & $\begin{array}{c}0.285 \\
(8.644)\end{array}$ & $\begin{array}{c}0.018 \\
(0.034)\end{array}$ & $\begin{array}{l}-0.001 \\
(0.029)\end{array}$ & $\begin{array}{c}0.004 \\
(0.019)\end{array}$ \\
\hline P-value & 0.000 & 0.814 & 0.331 & 0.974 & 0.595 & 0.982 & 0.845 \\
\hline Comparison mean & 15.640 & 0.047 & 51.015 & 101.885 & 0.418 & 0.245 & 0.089 \\
\hline $\mathrm{N}$ & 961 & 980 & 980 & 980 & 980 & 980 & 982 \\
\hline P-val male $=$ fem & 0.062 & 0.060 & 0.634 & 0.859 & 0.819 & 0.964 & 0.670 \\
\hline
\end{tabular}

Notes: See Table 2 Notes. 
Table B4: Can IV estimates be recovered with ML?

\begin{tabular}{|c|c|c|c|c|c|c|c|}
\hline & $\begin{array}{c}(1) \\
\text { Total } \\
\text { standardized } \\
\text { score } \\
(2013) \\
\end{array}$ & $\begin{array}{c}(2) \\
\text { Number } \\
\text { children } \\
\text { ever had } \\
(2017)\end{array}$ & $\begin{array}{c}(3) \\
\text { Preventive } \\
\text { health } \\
\text { index } \\
(2013) \\
\end{array}$ & $\begin{array}{c}(4) \\
\text { Ever } \\
\text { enrolled } \\
\text { in tertiary } \\
(2019)\end{array}$ & $\begin{array}{c}(5) \\
\text { Wage } \\
\text { contract w/ } \\
\text { employer } \\
(2019)\end{array}$ & $\begin{array}{c}(6) \\
\text { Earnings } \\
\text { in last } \\
6 \text { mos. } \\
(2019)\end{array}$ & $\begin{array}{c}(7) \\
\text { Earnings } \\
\text { in last } \\
6 \text { mos. } \\
(2020)\end{array}$ \\
\hline \multicolumn{8}{|l|}{ Panel A: Female } \\
\hline OLS with no controls & $\begin{array}{c}0.263 \\
(0.018)\end{array}$ & $\begin{array}{l}-0.205 \\
(0.015)\end{array}$ & $\begin{array}{c}0.003 \\
(0.016)\end{array}$ & $\begin{array}{c}0.092 \\
(0.005)\end{array}$ & $\begin{array}{c}0.026 \\
(0.005)\end{array}$ & $\begin{array}{l}137.936 \\
(31.230)\end{array}$ & $\begin{array}{l}206.999 \\
(45.730)\end{array}$ \\
\hline OLS with controls & $\begin{array}{c}0.254 \\
(0.018)\end{array}$ & $\begin{array}{l}-0.205 \\
(0.015)\end{array}$ & $\begin{array}{l}-0.007 \\
(0.017)\end{array}$ & $\begin{array}{c}0.091 \\
(0.005)\end{array}$ & $\begin{array}{c}0.025 \\
(0.005)\end{array}$ & $\begin{array}{l}139.457 \\
(32.452)\end{array}$ & $\begin{array}{l}200.938 \\
(44.864)\end{array}$ \\
\hline DoubleML & $\begin{array}{c}0.217 \\
(0.021)\end{array}$ & $\begin{array}{l}-0.160 \\
(0.018)\end{array}$ & $\begin{array}{c}-0.009 \\
(0.016)\end{array}$ & $\begin{array}{c}0.084 \\
(0.005)\end{array}$ & $\begin{array}{c}0.021 \\
(0.004)\end{array}$ & $\begin{array}{l}129.643 \\
(26.564)\end{array}$ & $\begin{array}{l}158.062 \\
(32.445)\end{array}$ \\
\hline Weighted DML & $\begin{array}{c}0.205 \\
(0.020)\end{array}$ & $\begin{array}{l}-0.127 \\
(0.018)\end{array}$ & $\begin{array}{c}-0.001 \\
(0.017)\end{array}$ & $\begin{array}{c}0.095 \\
(0.005)\end{array}$ & $\begin{array}{c}0.023 \\
(0.004)\end{array}$ & $\begin{array}{l}148.526 \\
(27.902)\end{array}$ & $\begin{array}{l}207.576 \\
(35.928)\end{array}$ \\
\hline IV & $\begin{array}{c}0.154 \\
(0.049)\end{array}$ & $\begin{array}{l}-0.149 \\
(0.052)\end{array}$ & $\begin{array}{c}0.095 \\
(0.041)\end{array}$ & $\begin{array}{c}0.061 \\
(0.015)\end{array}$ & $\begin{array}{c}0.033 \\
(0.013)\end{array}$ & $\begin{array}{c}28.326 \\
(85.815)\end{array}$ & $\begin{array}{c}193.045 \\
(100.333)\end{array}$ \\
\hline Panel B: Male & & & & & & & \\
\hline OLS with no controls & $\begin{array}{c}0.167 \\
(0.018)\end{array}$ & $\begin{array}{l}-0.086 \\
(0.014)\end{array}$ & $\begin{array}{c}0.017 \\
(0.017)\end{array}$ & $\begin{array}{c}0.101 \\
(0.005)\end{array}$ & $\begin{array}{c}0.013 \\
(0.006)\end{array}$ & $\begin{array}{c}22.115 \\
(34.621)\end{array}$ & $\begin{array}{l}207.645 \\
(55.471)\end{array}$ \\
\hline OLS with controls & $\begin{array}{c}0.158 \\
(0.018)\end{array}$ & $\begin{array}{l}-0.086 \\
(0.014)\end{array}$ & $\begin{array}{c}0.018 \\
(0.017)\end{array}$ & $\begin{array}{c}0.099 \\
(0.005)\end{array}$ & $\begin{array}{c}0.013 \\
(0.005)\end{array}$ & $\begin{array}{c}14.629 \\
(34.425)\end{array}$ & $\begin{array}{l}192.883 \\
(55.398)\end{array}$ \\
\hline DoubleML & $\begin{array}{c}0.095 \\
(0.016)\end{array}$ & $\begin{array}{l}-0.060 \\
(0.013)\end{array}$ & $\begin{array}{c}0.025 \\
(0.014)\end{array}$ & $\begin{array}{c}0.098 \\
(0.005)\end{array}$ & $\begin{array}{c}0.009 \\
(0.005)\end{array}$ & $\begin{array}{c}30.284 \\
(33.930)\end{array}$ & $\begin{array}{l}192.452 \\
(47.894)\end{array}$ \\
\hline Weighted DML & $\begin{array}{c}0.119 \\
(0.018)\end{array}$ & $\begin{array}{l}-0.058 \\
(0.012)\end{array}$ & $\begin{array}{c}0.026 \\
(0.016)\end{array}$ & $\begin{array}{c}0.099 \\
(0.005)\end{array}$ & $\begin{array}{c}0.007 \\
(0.005)\end{array}$ & $\begin{array}{c}23.495 \\
(34.081)\end{array}$ & $\begin{array}{l}221.721 \\
(52.930)\end{array}$ \\
\hline IV & $\begin{array}{c}0.094 \\
(0.047)\end{array}$ & $\begin{array}{l}-0.029 \\
(0.040)\end{array}$ & $\begin{array}{c}0.080 \\
(0.044)\end{array}$ & $\begin{array}{c}0.009 \\
(0.022)\end{array}$ & $\begin{array}{c}0.031 \\
(0.019)\end{array}$ & $\begin{array}{c}-11.072 \\
(125.353)\end{array}$ & $\begin{array}{l}-141.235 \\
(167.290\end{array}$ \\
\hline
\end{tabular}

Notes: See text section 8 for details. Panel A shows results for females; Panel B for males. Row 1 shows results from an OLS regression (control group only) with years of education as the dependent variable and without any controls. Row 2 shows results from an OLS regression (control group only) with years of education as the dependent variables and controlling for region fixed effects, JHS finishing exam score (BECE), and missing JHS finishing exam scores. Row 3 shows results using the Double Machine Learning (DML) procedure for the control group. Row 4 shows results using the DML procedure, weighting the control group to be representative of a sample resembling the treatment group compliers, based on baseline observables. Row 5 shows results from IV regressions, instrumenting years of education with treatment, and with the same controls as in the OLS with controls specification. Refer to Table A7 for the components of the preventive health index. Earnings are winsorized at the $99 \%$ level. In 2013, 1,280 observations for OLS and 1,907 observations for IV. In 2017, 1,266 observations for OLS and 1,891 for IV. In 2019, 1,297 observations for OLS and 1,951 for IV. In 2019, 1,131 observations for OLS and 1,722 for IV. 